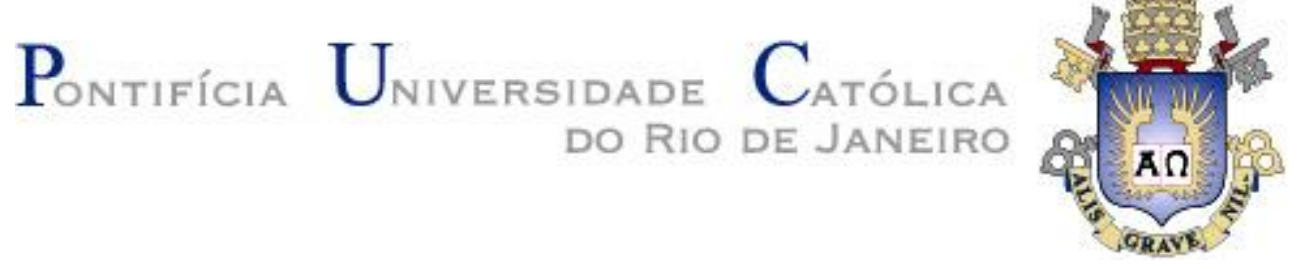

Anielle Cristine Farias Queiroz dos Santos

\title{
VIVÊNCIA DA PARENTALIDADE COM FILHO SURDO: DESAFIOS E POSSIBILIDADES
}

Dissertação de Mestrado

Dissertação apresentada ao Programa de Pós-Graduação em Psicologia Clínica da PUC-Rio como requisito parcial para obtenção do título de Mestre em Psicologia Clínica.

Orientadora: Prof ${ }^{a}$. Drª ${ }^{\text {- }}$. Andrea Seixas Magalhães 


\title{
Anielle Cristine Farias Queiroz dos Santos
}

\author{
Vivência da parentalidade com filho \\ surdo: desafios e possibilidades
}

\begin{abstract}
Dissertação apresentada como requisito parcial para obtenção do grau de Mestre pelo Programa de Pós-Graduação em Psicologia (Psicologia Clínica) da PUC-Rio. Aprovada pela Comissão Examinadora.
\end{abstract}

Prof ${ }^{a}$. Andrea Seixas Magalhães

Orientadora

Departamento de Psicologia - PUC-Rio

Profa ${ }^{2}$. Terezinha Féres-Carneiro Departamento de Psicologia - PUC-Rio

Prof‥ Fernanda Travassos Rodriguez

Sem vínculo

Rio de Janeiro, 21 de março de 2019. 
Todos os direitos reservados. É proibida a reprodução total ou parcial do trabalho sem autorização da universidade, da autora e da orientadora.

\section{Anielle Cristine Farias Queiroz dos Santos}

Graduação em Psicologia (2014) pela Pontifícia Universidade Católica do Rio de Janeiro (PUC-Rio). Formação clínica em Accelerated Experiential Dynamic Psychotherapy (2015) pelo Instituto AEDP Brasil. Formação clínica em Somatic Experiencing (2018) pela Associação Brasileira do Trauma. Atua na área de Psicologia Clínica.

Ficha Catalográfica

Santos, Anielle Cristine Farias Queiroz dos

Vivência da parentalidade com filho surdo: desafios e possibilidades / Anielle Cristine Farias Queiroz dos Santos ; orientadora: Andrea Seixas Magalhães. - 2019.

102 f. : il. color. ; $30 \mathrm{~cm}$

Dissertação (mestrado)-Pontifícia Universidade Católica do Rio de Janeiro, Departamento de Psicologia, 2019.

Inclui bibliografia

1. Psicologia - Teses. 2. Surdez. 3. Parentalidade. 4. Família. I. Magalhães, Andrea Seixas. II. Pontifícia Universidade Católica do Rio de Janeiro. Departamento de Psicologia. III. Título. 


\section{Agradecimentos}

Principalmente a Deus, que me proporciona o dom da vida. Meu coração se enche de gratidão por tudo que Tens feito por mim.

Ao meu marido André, por ter entendido e suportado minha ausência e os momentos em que não fui tão paciente. Você dividiu comigo as angústias e alegrias de cada etapa desse projeto. Meu amor, este trabalho é nosso! Obrigada por compreender minhas escolhas e desafios e aceitar vivenciá-los de mãos dadas comigo.

Aos meus pais, Rita e Anacleto, pelo amor incondicional e dedicação. Minha gratidão profunda por terem acreditado, investirem tanto em mim e por estarem ao meu lado me mostrando que posso sempre contar com vocês.

Ao meu paidrinho Maurílio, por ser um grande incentivador, pelo carinho, cuidado e por acreditar tanto em mim.

Ao meu psicoterapeuta Carlos Melo que, com tanto cuidado, persistência e sensibilidade, sempre busca o meu melhor e me encoraja a viver de forma mais inteira, autêntica, criativa e leve. Muita gratidão por me ajudar a "equilibrar a gangorra".

À querida amiga Érica que, com sua presença constante e segura, seu carinho, incentivo e disponibilidade, tornaram a caminhada mais suave. Agradeço especialmente às preciosas leituras e sugestões. Você foi imprescindível para a conclusão deste trabalho.

Às queridas amigas Aurea, Cíntia, Deborah, Dinéa, Enoã e Renata pelas orações, carinho, incentivo e momentos de descontração quando estava no meu limite. Obrigada por estarem ao meu lado, respeitando as minhas limitações e ausências.

Às queridas companheiras do grupo da pós-graduação, Carla, Débora, Fernanda, Juliana e Mariana pela continência, trocas, aprendizado e incentivo. Vocês tornaram a caminhada menos solitária.

À minha orientadora, Prof. ${ }^{a}$ Dr. ${ }^{a}$ Andrea Seixas Magalhães que, com toda sua competência, seriedade e dedicação, me acompanhou, sempre disponibilizando seu tempo e conhecimento. Obrigada pela oportunidade de estar mais uma vez comigo e por todas as contribuições ao longo do processo.

À Prof. ${ }^{a}$ Dr. ${ }^{a}$ Mayla Cosmo, pela coorientação, disponibilidade e acolhimento extremamente seguros, cuidadosos, pacientes e competentes com que me recebeu durante todo este trabalho. Minha profunda gratidão e carinho.

À Prof. ${ }^{a}$ Regina Pontes, por me apresentar à AEDP, a abordagem terapêutica mais bonita, humana e encantadora que já conheci. Obrigada por todo carinho, cuidado, segurança e aprendizado ao longo do meu percurso profissional e pessoal e as 
marcantes contribuições na minha prática clínica. Muita gratidão por compartilhar seu saber e curiosidade de forma tão generosa e por sempre me estimular a crescer.

À Prof. ${ }^{a}$ Dr. ${ }^{a}$ Terezinha Féres-Carneiro, por ter aceitado o convite de participar da banca examinadora desta dissertação. Minha gratidão por todo carinho, confiança, aprendizado e incentivo desde o tempo em que participava do grupo de pesquisa.

À Prof. ${ }^{a}$ Dr. ${ }^{a}$ Fernanda Travassos, cujas contribuições, compreensão, carinho e cuidado foram inestimáveis no Exame de Qualificação. Obrigada por ter aceitado o convite de participar da banca examinadora desta dissertação. E por orientar e incentivar minha caminhada desde a graduação.

Ao CNPq - Conselho Nacional de Desenvolvimento Científico e Tecnológico, pelo suporte financeiro para a realização desta pesquisa.

Agradeço especialmente aos pais e mães entrevistados que, de forma tão generosa e corajosa, aceitaram abrir seus corações e compartilhar comigo suas histórias, permitindo que eu conhecesse suas vivências. Meu respeito, gratidão e admiração. 


\section{Resumo}

Santos, Anielle Cristine Farias Queiroz dos; Magalhães, Andrea Seixas (Orientadora). Vivência da parentalidade com filho surdo: desafios e possibilidades. Rio de Janeiro, 2019. 102p. Dissertação de Mestrado - Programa de Pós-Graduação em Psicologia Clínica, Pontifícia Universidade Católica do Rio de Janeiro.

A confirmação do diagnóstico de surdez do filho pode provocar conflitos internos nos pais ouvintes, dificultando o investimento emocional e afetivo no filho surdo. Diante da importância da família para a promoção do desenvolvimento da criança, esta pesquisa teve como objetivo investigar como pais e mães ouvintes vivenciam a parentalidade com um filho surdo. Para tal, consideramos importante abordar a definiçãa de surdez e as possíveis causas, tipos, graus e tratamento da perda auditiva, as concepções socioculturais da surdez e a cultura surda. Para uma melhor compreensão do impacto do diagnóstico no exercício da parentalidade, abordamos algumas questões referentes ao nascimento de uma criança muito diferente da esperada pelos pais, a adaptação/aproximação com a criança surda que exige um processo de luto - e as particularidades da interação entre os pais ouvintes e o filho surdo. Realizamos um estudo qualitativo. Foram entrevistados oito sujeitos independentes, pais e mães ouvintes (quatro homens e quatro mulheres). A partir da análise do material discursivo das entrevistas dos participantes, emergiram seis categorias: 1) Descoberta da surdez: da suspeita à confirmação do diagnóstico; 2) Confirmação do diagnóstico: luto na parentalidade com um filho surdo; 3) O ideal do filho falante; 4) (Des)conhecimento da surdez e sua influência nos cuidados parentais; 5) Rede de apoio na surdez; 6) Tornandose pais resilientes. Constatamos que a confirmação do diagnóstico de surdez do filho é uma situação complexa para os pais ouvintes. A diferença significativa entre a criança idealizada e a real, que não nasceu "normal" e "saudável", é um desafio a ser enfrentado pelos pais, que apresentaram muitas dificuldades em aceitar o diagnóstico. Somado a isso, a compreensão da surdez como patologia e, diante disso, a busca do implante coclear como meio de viabilizar "a cura" do filho, atuam também como dificultadores do processo de aceitação e enfrentamento. A vivência do luto pelo filho idealizado, das emoções e dos sentimentos decorrentes deste 
processo, assim como o suporte da rede de apoio e o conhecimento acerca da surdez e das potencialidades da pessoa surda são elementos essenciais que possibilitaram aos pais ressignificar o diagnóstico e se relacionar com o filho surdo. Isto repercutiu no processo de resiliência frente à surdez do filho e na promoção de saúde de todos os membros da família. Os resultados desse estudo apontam, ainda, a necessidade de apoio e orientação para os pais ouvintes, que muitas vezes ficam mobilizados e desorientados frente à criação de um filho surdo.

\section{Palavras-chave}

Surdez; parentalidade; família. 


\section{Abstract}

Santos, Anielle Cristine Farias Queiroz dos; Magalhães, Andrea Seixas (Orientadora). Experience of parenting with deaf children: challenges and possibilities. Rio de Janeiro, 2019. 102p. Dissertação de Mestrado - Programa de Pós-Graduação em Psicologia Clínica, Pontifícia Universidade Católica do Rio de Janeiro.

Confirmation of the diagnosis of deafness of one's child may provoke internal conflicts in the hearing parents, hindering the emotional and affective investment in the deaf child. Given the importance of the family for the promotion of child development, this research aimed to investigate how hearing mothers and fathers experience parenting with a deaf child. To that end, we consider it important to address the definition of deafness and its possible causes, types, degrees and treatment of hearing loss, sociocultural conceptions of deafness and deaf culture. For a better understanding of the impact of the diagnosis in the exercise of parenting, we address some questions regarding the birth of a child very different from that expected by the parents, the adaptation / approximation with the deaf child - which requires a grieving process - and the particularities of the interaction between the hearing parents and the deaf child. We performed a qualitative study. Eight independent subjects, hearing parents (four men and four women) were interviewed. From the analysis of the discursive material of the participants' interviews, six categories emerged: 1) Discovery of deafness: from suspicion to confirmation of diagnosis; 2) Confirmation of the diagnosis: mourning in parenthood with a deaf child; 3) The ideal of the talking son; 4) (Un) knowledge of deafness and its influence on parental care; 5) Support network in deafness; 6) Becoming resilient parents. We found that confirming the deafness diagnosis of the child is a complex situation for the hearing parents. The significant difference between the idealized and the real child, who was not born "normal" and "healthy", is a challenge to be faced by the parents, who presented many difficulties in accepting the diagnosis. In addition, the understanding of deafness as a pathology and, in the face of this, the search for cochlear implants as a means of enabling the child to "heal" also act as obstacles to the process of acceptance and coping. The experience of mourning for the idealized child, the emotions and feelings resulting 
from this process, as well as the support network and the knowledge about deafness and the potentialities of the deaf person are essential elements that enabled the parents to resignify the diagnosis and to relate with the deaf child. This had repercussions on the process of resilience to the deafness of the child and on the health promotion of all family members. The results of this study also point to the need for support and guidance for the hearing parents, who are often mobilized and disoriented in the face of the creation of a deaf child.

\section{Keywords}

Deafness; parenting; family. 


\section{LISTA DE ABREVIATURAS E SIGLAS}

AASI Aparelho de Amplificação Sonora Individual

AEDP Accelerated Experiential Dynamic Psychotherapy

Apae Associação de Pais Amigos dos Excepcionais

BIAP Bureau International d'Audiophonologie

$\mathrm{dB} \quad$ Decibéis

EOA Emissões Otoacústicas

IBGE Instituto Brasileiro de Geografia e Estatística

IC Implante Coclear

INES Instituto Nacional de Educação de Surdos

Libras Língua Brasileira de Sinais

OMS Organização Mundial de Saúde

SUS Sistema Único de Saúde

TANU Triagem Auditiva Neonatal

TDD Telephone Device for Deaf (Aparelho de Telefone para Surdos)

UTI Unidade de Terapia Intensiva

WHO World Health Organisation 


\section{LISTA DE ILUSTRAÇÕES}

Figura 1 O ouvido humano 20

Figura 2 Aparelho de amplificação sonora 22

Figura 3 Implante coclear 23

Quadro 1 Dados de identificação dos participantes 49 


\section{Sumário}

1 Introdução

2 A surdez 18

2.1 A surdez na infância 18

2.2 A surdez como fenômeno cultural 24

$\begin{array}{ll}2.3 \text { A cultura surda } & 27\end{array}$

3 Tornando-se pais de filhos surdos 32

3.1 nascimento de um filho inesperado 32

3.2 A confirmação do diagnóstico de surdez e o luto pelo filho perfeito 35

3.3 Aspectos relevantes da parentalidade com um filho surdo 41

4 Desvelando a parentalidade: estudo de campo 48

4.1 Participantes 48

4.2 Instrumentos da pesquisa 48

4.3 Procedimentos $\quad 50$

4.4 Análise e discussão dos dados $\quad 50$

Descoberta da surdez: da suspeita à confirmação do diagnóstico 51

Confirmação do diagnóstico: luto na parentalidade com um filho surdo 55

$\begin{array}{ll}\text { O ideal do filho falante } & 61\end{array}$

(Des)conhecimento da surdez e sua influência nos cuidados parentais 66

$\begin{array}{ll}\text { Rede de apoio na surdez } & 71\end{array}$

$\begin{array}{ll}\text { Tornando-se pais resilientes } & 77\end{array}$

5 Considerações finais $\quad 84$

6 Referências bibliográficas $\quad 89$ 
Anexo 1

Anexo 2

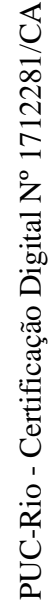




\section{Bem-vindo à Holanda!}

Ter um bebê é como planejar uma fabulosa viagem de férias - para a Itália. Você compra montes de guias, faz planos maravilhosos. O Coliseu... O David de Michelangelo... as gôndolas em Veneza. Você até pode aprender algumas frases simples em italiano. É tudo muito excitante!

Após meses de ansiosa expectativa, finalmente chega o grande dia. Você arruma as suas malas e embarca. Algumas horas depois aterra... O comissário de bordo chega e diz: - "Bem-vindo à HOLANDA!". "HOLANDA!?" diz você - "Como assim Holanda? Eu escolhi Itália! Toda minha vida sonhei conhecer a Itália”. Mas houve uma mudança no plano de voo. Eles aterrissaram na Holanda e é lá que você deve ficar...

A coisa mais importante é que não te levaram para um lugar horrível, desagradável, com fome e com doenças. É apenas um lugar diferente. Logo, você deve sair e comprar novos guias. Deve aprender um novo idioma. E você vai conhecer todo um novo grupo de pessoas que você nunca teria conhecido. É apenas um lugar diferente. É mais baixo e menos ensolarado que Itália. Mas, após alguns minutos, você pode respirar fundo e olhar ao redor... e começar a notar que a Holanda tem moinhos de vento, tulipas e até Rembrandts e Van Goghs. Mas, todas as pessoas que você conhece estão ocupadas indo e vindo da Itália, e estão sempre comentando sobre o tempo maravilhoso que passaram lá. E toda a sua vida você vai dizer: "Sim, lá era onde eu deveria estar. É o que eu tinha planejado". E a dor que isso causa nunca, nunca irá embora, porque a perda desse sonho é uma perda extremamente significativa.

Porém... se você passar a sua vida toda remoendo o fato de não ter chegado a Itália, nunca estará livre para apreciar as coisas belas e muito especiais da Holanda. 


\section{1 \\ Introdução}

A temática da surdez faz parte do meu percurso profissional há mais de 10 anos e sempre me fascinou, tendo sido iniciado com a minha atuação como intérprete da Língua Brasileira de Sinais (Libras). Durante a graduação no Curso de Psicologia pela Pontifícia Universidade Católica do Rio de Janeiro, pude entrelaçar meu conhecimento sobre a surdez e sobre a Libras com a psicologia, realizando estágios na área da psicologia escolar e clínica em instituições especializadas em surdez e, ainda, pude desenvolver trabalhos em algumas disciplinas sobre este tema. Em paralelo, ao longo da graduação e depois de formada, participei do grupo de pesquisa na área de família e casal coordenado pelas professoras Andrea Seixas Magalhães e Terezinha Féres-Carneiro, estudando sobre a parentalidade. Após a graduação, iniciei a formação clínica em Accelerated Experiential Dynamic Psychotherapy (AEDP) - NeuroPsicoTerapia e em Somatic Experiencing (Experiência Somática), ocasião em que pude aprofundar os estudos acerca da importância do vínculo e da segurança para explorarmos o mundo a nossa volta, além do impacto dos traumas no desenvolvimento, ocorridos nas vivências cotidianas e nas relações com os pais ou figuras significativas. Nos últimos quatro anos, tenho atuado como psicóloga clínica em consultório particular, e atuei durante um ano em uma instituição especializada em surdez, atendendo pacientes surdos e seus familiares, tendo a oportunidade de articular a teoria à prática.

Em todas essas situações, temas relacionados à família, à surdez, à psicologia clínica e à clínica com crianças estavam presentes e me deixavam intrigada. $\mathrm{Na}$ prática clínica, em diversos momentos, percebia obstáculos no trabalho devido à dificuldade da interação, principalmente com relação à comunicação, entre pais ouvintes e filhos surdos. Os pais demonstravam dificuldade em aceitar a surdez e relatavam muito pesar e angústia. Os filhos surdos também descreviam suas aflições e intenso sofrimento com a situação. A falta de uma língua em comum entre pais e filhos, o desconhecimento sobre a surdez e a descrença nos potenciais do filho surdo geraram em mim alguns questionamentos e despertaram meu interesse para compreender melhor a vivência destes pais e, se possível, adquirir recursos para auxiliar na interação com os filhos. 
De acordo com a Organização Mundial de Saúde (OMS), o termo "surdo" é utilizado para se referir a pessoas que têm uma perda auditiva bilateral severa a profunda, ou seja, que têm uma lesão nos dois ouvidos, cuja audição não é funcional no dia a dia e usa a língua de sinais para se comunicar (WHO, 2018). No Brasil, é estimado que $6,2 \%$ da população sejam portadores de alguma deficiência, e a auditiva representa um percentual de 3,65\% desse total. Existem aproximadamente 455 mil surdos no país (IBGE, 2015). A maioria (95\%) das crianças surdas são filhas de pais ouvintes, dos quais, a maior parte, não tem um histórico de surdez na família e, por vezes, nunca tiveram contato com uma pessoa surda (Felipe, 2009). Desconhecem, portanto, as particularidades da surdez e, na maioria das vezes, percebem-na apenas como uma deficiência (Stelling, Stelling, Torres \& Castro, 2014; Yamada, Moretti, Prado \& Belavicqua, 2014; Silva \& Gonçalves, 2013).

Ao longo da gestação, a maioria dos pais cria expectativas acerca da criança, imaginam sexo, nome, características físicas, dentre outras. $\mathrm{O}$ bebê idealizado pelos pais ao longo da gravidez é sempre diferente da criança que vem ao mundo (Lebovici, 1987). Quando nasce um bebê considerado "normal", os pais vivenciam um processo de luto comum ao nascimento de qualquer criança, uma elaboração da imagem do bebê idealizado e a adaptação ao bebê real (Travassos-Rodriguez \& Féres-Carneiro, 2012). No entanto, com a confirmação do diagnóstico de surdez, atestando o nascimento de uma criança muito diferente da idealizada, os pais apresentam maior dificuldade em elaborar o luto do filho que não nasceu "normal" e "saudável", tornando difícil o investimento emocional e afetivo no filho surdo (Asano, Neme \& Yamada, 2010; Góes, 2006; Sá \& Rabinovich, 2006). A família apresenta dificuldades para aceitar a surdez do filho, buscando um atendimento tardio, o que pode gerar prejuízos significativos no desenvolvimento da criança (Negrelli \& Marcon, 2006; Silva, Pereira \& Zanolli, 2012; Silva, Zanolli \& Pereira, 2008).

Frente a esta situação, podemos pensar que o desconhecimento a respeito da surdez e a dificuldade da vivência do luto pela perda do filho idealizado constituemse questões delicadas. Diante dos poucos estudos sobre a vivência dos pais, destacamos a importância de aprofundar a compreensão acerca do processo de tornar-se pai/mãe de uma criança surda, visando a contribuir de forma mais eficaz para o desenvolvimento de intervenções junto aos surdos e seus familiares, oferecendo subsídios para promover a saúde da família. 
O objetivo geral desta dissertação foi desenvolver uma investigação sobre como os pais e mães ouvintes vivenciam a parentalidade com um filho surdo. Como objetivos específicos, buscamos: investigar o impacto do diagnóstico da surdez para os pais ouvintes e identificar os facilitadores e os dificultadores do exercício da parentalidade no contexto de pais ouvintes e filho surdo. Realizamos uma pesquisa de campo e apresentamos a dissertação nos capítulos subsequentes.

O primeiro capítulo da fundamentação teórica aborda a surdez na infância, apresentando em sua primeira parte a definição, possíveis causas, tipos e graus da perda auditiva, nomenclatura e o processo de diagnóstico e tratamento. Consideramos importante apresentar algumas discussões sobre as concepções socioculturais da surdez e a cultura surda. Para abordar estes temas, baseamo-nos nas contribuições de estudos neurocientíficos e médicos da área da otorrinolaringologia e nas contribuições de Behares, Carlos Skliar e Karin Strobel.

Em seguida, buscamos compreender melhor sobre a parentalidade com filhos surdos. Em um primeiro momento, foram discutidas questões referentes ao nascimento de um bebê muito diferente do esperado, particularmente nos primeiros momentos após o nascimento. A perda do filho idealizado e a adaptação/aproximação do filho surdo exigem longo e delicado trabalho de elaboração de luto, processo que será abordado em seguida. Discutimos essas questões, principalmente, através das contribuições de Serge Lebovici, Sigmund Freud, David Luterman, Robert Neimeyer e Cassia Asano. Na parte final, abordamos as particularidades da interação de pais ouvintes com um filho surdo. Para fundamentar este tema baseamo-nos nos estudos de Angélica Silva, Zélia Bittencourt, Midori Yamada, dentre os outros pesquisadores sobre o tema.

Após a fundamentação teórica, apresentamos o estudo de campo realizado com oito pais ouvintes, sujeitos independentes (quatro homens e quatro mulheres), e a discussão dos resultados obtidos a partir das entrevistas realizadas com eles. As considerações finais são expostas no capítulo seguinte, considerando a vivência e o processo de aceitação e enfrentamento da surdez pelos pais ouvintes. Convidamos o leitor a acompanhar o percurso que realizamos nesse estudo, levando-o a conhecer o universo dos pais ouvintes com filhos surdos. 


\title{
2
}

\section{A surdez}

\begin{abstract}
"Recuso-me a ser considerada excepcional, deficiente. Não sou. Sou surda. Para mim, a língua de sinais corresponde à minha voz, meus olhos são meus ouvidos. Sinceramente nada me falta. É a sociedade que me torna excepcional." (Laborit, 1996, p. 26)
\end{abstract}

Este capítulo tem como objetivo abordar a surdez na infância, apresentando em sua primeira parte a definição, possíveis causas, tipos e graus da perda auditiva, nomenclatura e o processo de diagnóstico e tratamento. Consideramos importante apresentar algumas discussões sobre as concepções socioculturais da surdez e a cultura surda.

\section{1}

\section{A surdez na infância}

A OMS estima que 466 milhões de pessoas no mundo sofram de perda auditiva incapacitante, sendo que 34 milhões são crianças e adolescentes, com idade igual ou inferior a 15 anos (WHO, 2018). No Brasil, é estimado que 6,2\% da população sejam portadores de alguma deficiência, e a auditiva representa um percentual de 3,65\% desse total. Existem aproximadamente 455 mil surdos no país (IBGE, 2015).

Os conceitos gerais sobre a surdez, suas classificações, características dos diversos tipos de perda auditiva, técnicas e métodos de avaliação, a fase em que foi adquirida (pré ou pós-lingual), por exemplo, são fundamentais para definir a perda auditiva e compreender as implicações da surdez. A seguir, os aspectos médicos e biológicos dessa condição serão apresentados.

O sistema auditivo começa a se desenvolver, em sua porção periférica, desde a vigésima semana de gestação e continua se desenvolvendo intensamente nos primeiros meses de vida. Ao nascer, o bebê já pode apresentar uma perda auditiva ou adquiri-la ao longo da vida. Isto pode acontecer mesmo que não haja casos de surdez na família ou nenhum indicador de risco evidente (Miniti, Bento \& Butugan, 2001). 
A perda auditiva consiste na diminuição ou na ausência total do sentido da audição, quando os limiares auditivos detectados são maiores que 20 decibéis (dB). Ela pode afetar um ou ambos os ouvidos e pode ser classificada em graus de severidade, do leve ao profundo, com base na detecção dos sons em decibéis em diferentes faixas de frequências sonora (BIAP, 1997). Quanto maior for a perda, maior será o impedimento auditivo. Um indivíduo com perda auditiva leve (entre 21 e $40 \mathrm{~dB}$ ) tem dificuldade para entender a fala emitida com pequena intensidade, mas essa perda não o impede de se comunicar por uma língua oral. Nos casos de perda profunda (acima de $91 \mathrm{~dB}$ ), o indivíduo tem acesso apenas a sons intensos ou percebe somente vibrações. Desta forma, não utiliza a audição para acessar as informações do mundo e não adquire a língua oral, de forma natural, como modalidade principal de comunicação.

As alterações auditivas podem ocorrer em diferentes partes do ouvido (Figura 1), sendo classificadas em: condutiva, neurossensorial, mista ou central. A perda auditiva é considerada condutiva quando existe interferência no mecanismo de transmissão do som desde o condutivo externo até o ouvido interno. O ouvido interno, nesse tipo de perda, pode ter sua capacidade de funcionamento normal, mas esse tipo de lesão impede que o som seja eficazmente conduzido. A neurossensorial se caracteriza quando ocorre uma alteração no mecanismo de transformação do som em impulso neuroelétrico. Nesse tipo de perda, há uma impossibilidade de recepção do som em função de uma má formação das células ciliadas da cóclea ou das fibras no nervo auditivo. A perda mista é descrita quando os dois tipos de perdas citados anteriormente coexistem, tratando-se de uma alteração na condução do som associada a uma lesão do órgão sensorial ou do nervo auditivo. E a perda central se configura quando há uma alteração nos mecanismos de processamento da informação sonora no tronco cerebral, decorrente de lesões bilaterais do tronco cerebral e regiões subcorticais (Miniti, Bento \& Butugan, 2001).

A causa da perda auditiva na infância pode ocorrer por diversos fatores, sendo classificados em pré-natais, perinatais e pós-natais. As causas pré-natais mais comuns são por infecções congênitas (rubéola, sífilis, toxoplasmose, herpes, sífilis, citomegalovírus e outras infecções virais e bacterianas), devido ao uso de medicações ototóxicas durante a gravidez e fatores genéticos hereditários. As perinatais são anóxia, icterícia, hiperbilirrubinemia, nascimentos abaixo do peso ideal e falta de oxigênio na hora do parto. E as pós-natais quando, nos primeiros 
meses de vida da criança, ocorrem infecções bacterianas e virais (sarampo, rubéola, caxumba e meningite), ototoxidade, otite média crônica ou por acidentes e lesões na cabeça ou ouvido (WHO, 2018).

Figura 1. O ouvido humano

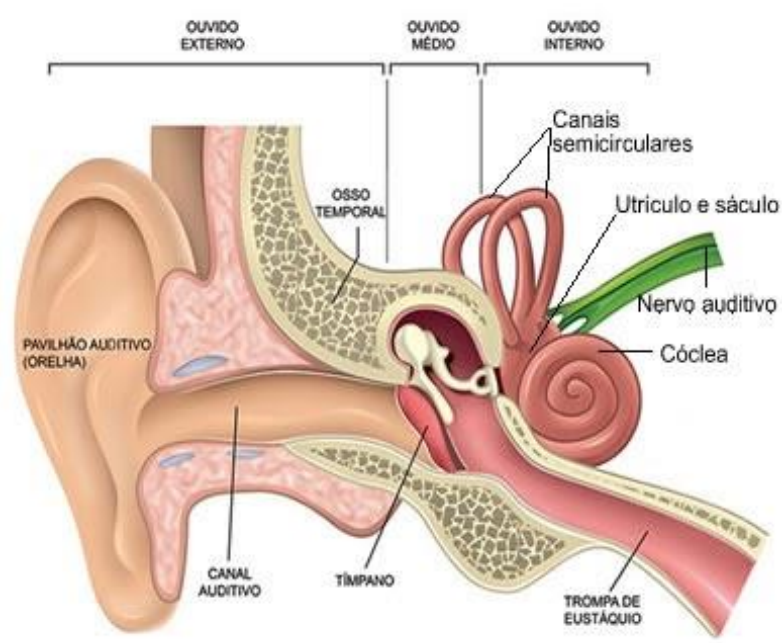

Fonte: Köhler Ortofacial, 2011.

No Brasil, alguns estudos demonstraram que os indicadores mais relevantes para a perda auditiva em crianças são as causas perinatais, como anóxia, prematuridade e permanência em Unidade de Terapia Intensiva (UTI) por mais 48 horas, e a hereditariedade. Uma pesquisa realizada com 17 neonatos diagnosticados com perda auditiva neurossensorial em um programa de Triagem Auditiva Neonatal (TANU), em uma maternidade pública no município de Jundiaí (SP), observou como fator de risco mais frequente a permanência em UTI neonatal por tempo superior a 48 horas $(58,3 \%)$, seguido de prematuridade $(33,3 \%)$ (Pereira, Costa, Pomilio, Costa, Rodrigues \& Sartorato, 2014). Outro estudo, realizado com 31 neonatos diagnosticados com perda auditiva que participavam do processo diagnóstico em outra instituição no mesmo município, verificou, além dos fatores de risco supracitados, a história familiar $(29 \%)$ (Costa, 2016).

Em relação aos recém-nascidos prematuros provenientes de UTI, a incidência de deficiência auditiva é maior se comparada à incidência em recémnascidos a termo (Peñazola-López et al., 2004; Dalzell et al., 2000). Widen, Bull e Folsom (2000) estimam que duas crianças em cada 1000 nascimentos apresentam perda auditiva, aumentando para duas a cinco em cada 100 nascimentos quando 
estas permanecem na UTI. Os avanços médicos e tecnológicos permitem maior ocorrência de nascimento de crianças prematuras e de baixo peso que, em sua maioria, necessitam permanecer na UTI neonatal por certo tempo. No entanto, cabe salientar que não é a permanência em si que leva à perda, mas os fatores associados, como o uso de ventilação mecânica, os tratamentos com medicações ototóxicas e a exposição aos altos ruídos da UTI (Vieira, Miranda, Azevedo \& Garcia, 2007).

É importante mencionar a diminuição da incidência de infecções congênitas como fator de risco para a perda auditiva. Os estudos mais antigos sobre a etiologia da perda auditiva apontavam as infecções pré-natais, em especial a rubéola congênita, como um dos maiores indicadores de risco. A redução no número de casos pode estar relacionada com o aumento das medidas de prevenção primária, como campanhas de incentivo ao pré-natal e campanhas de vacinação. Uma pesquisa investigou o impacto da vacinação contra a rubéola no Brasil e demonstrou que os casos de infecção por essa doença diminuíram significativamente entre os anos de 2002 e 2005 (Lanzieri, Pinto \& Prevots, 2007).

A maioria dos estudos sobre a etiologia da perda auditiva menciona a importância do diagnóstico pré-natal e da triagem auditiva neonatal. A identificação precoce da perda auditiva e a implementação de tratamento adequado têm se mostrado eficazes para diminuir a ocorrência das perdas auditivas na infância. A Lei 12.303, de 2 de agosto de 2010, institui a obrigatoriedade do exame de Emissões Otoacústicas, conhecido como "Teste da Orelhinha", para as crianças nascidas em todos os hospitais e maternidades do país, preferencialmente, até os primeiros três meses de vida. Contudo, devido à precariedade do sistema de saúde brasileiro, esse exame não tem sido realizado de forma satisfatória (Alvarenga, Gadret, Araujo \& Bevilacqua, 2012; Marchand, Rech, Benvenutti, Soldera \& Machado, 2016). A literatura nacional indica que o diagnóstico das alterações auditivas ocorre tardiamente, por volta dos três ou quatro anos de idade, e o tempo entre a suspeita e confirmação da surdez é de 11 a 48 meses (Silva, Pereira \& Zanolli, 2012; Vieira, Bevilacqua, Ferreira \& Dupas, 2012).

Existem casos em que a audição pode ser recuperada com medicamentos e/ou procedimentos clínicos ou cirúrgicos, principalmente em casos de perdas condutivas. Nesse tipo de perda, em que a causa pode ser a presença de líquido no ouvido médio ou de cera no canal auditivo, um possível tratamento é drenar esse fluido ou eliminar a cera. Em casos de perfurações timpânicas e nas lesões dos 
ossículos (martelo, bigorna, estribo), o tratamento é cirúrgico. Na doença de Menière (surdez, tontura, zumbido), o tratamento é clínico e, às vezes, cirúrgico. Em casos de tumores, o tratamento indicado pode ser essencialmente cirúrgico, radioterápico ou radiocirúrgico (Miniti, Bento \& Butugan, 2001).

No entanto, muitas vezes, não é possível a recuperação da audição. Nestes casos, o tratamento consiste em compensar a perda auditiva através de recursos tecnológicos que permitem o acesso à percepção auditiva dos sons, como os Aparelhos de Amplificação Sonora Individual (AASI) e o implante coclear (IC). O AASI é o dispositivo de reabilitação mais comum, cuja função é amplificar os sons para chegar ao ouvido. Esses aparelhos são opções para reabilitar perdas leves a severas e podem ser usados em qualquer idade (Figura 2).

Figura 2. Aparelho de Amplificação Sonora

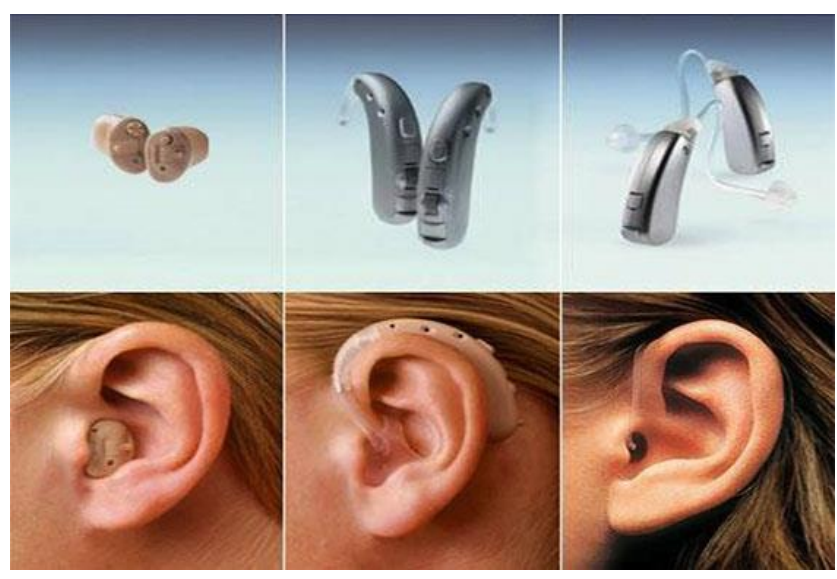

Fonte: Pacheco, 2012

Para as pessoas com perda auditiva severa a profunda que não se beneficiam com uso dos aparelhos auditivos, tem sido recomendado pelos profissionais de saúde o IC (Figura 3). Este procedimento cirúrgico consiste no implante de uma prótese auditiva eletrônica, que substitui ou complementa a função das células ciliadas ausentes ou danificadas da cóclea, desenvolvida para captar energia sonora mecânica, convertê-la em sinais elétricos e enviar esses estímulos, através do nervo auditivo, ao cérebro. No cérebro, esses estímulos são interpretados como sons. Essa prótese liga-se externamente a um dispositivo constituído de antena transmissora, microfone e processador da fala (Bevilacqua, Moret \& Costa, 2011). A implantação deste recurso requer avaliação minuciosa dos candidatos, com critérios estritos, e acompanhamento constante e a longo prazo dos procedimentos de ativação e 
mapeamento dos eletrodos por uma equipe multiprofissional (Magalhães, PérezRamoz, Neme \& Yamada, 2007).

Figura 3. Implante Coclear

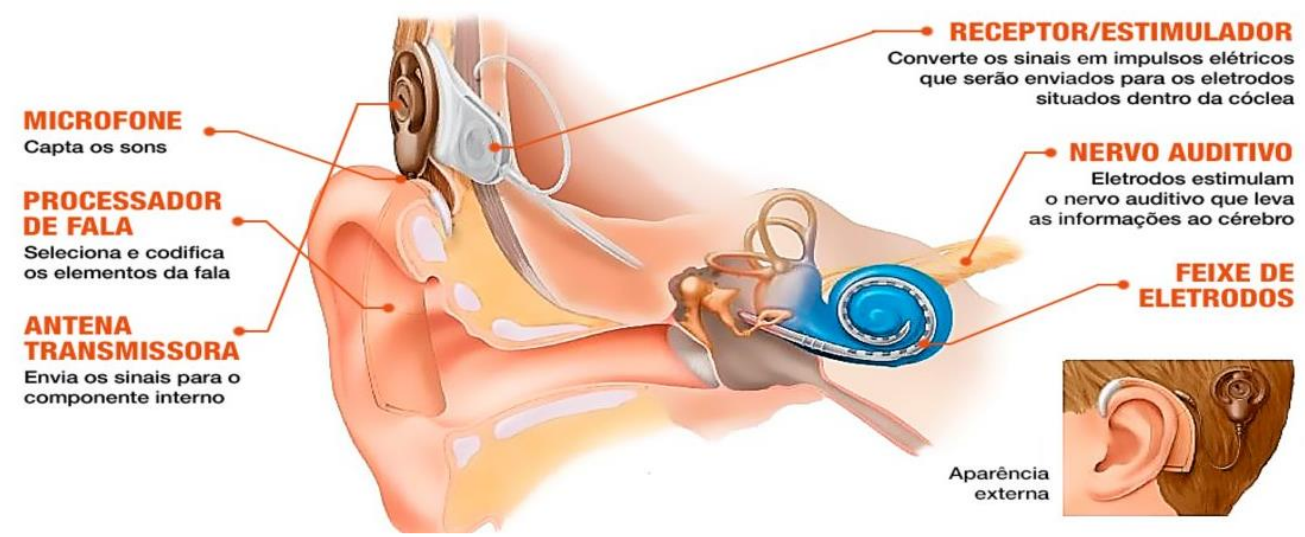

Fonte: adaptado de Fonseca, 2015

Os avanços tecnológicos para a identificação precoce da surdez e as intervenções através desses dispositivos tecnológicos, AASI e IC, são notórios. Cabe pontuar que esses recursos não restauram a audição dos usuários (Bevilacqua, Moret \& Costa, 2011). No caso do IC, por mais avançada que seja a sua tecnologia, as sensações auditivas que propicia diferem da audição normal. Apesar de melhorias consideráveis no desempenho auditivo, existe variabilidade nos resultados (Capovilla, 1998).

Alguns pais acreditam que apenas a utilização desses recursos garantirá aos filhos surdos a recuperação total da audição, permitindo a oralização e a integração na sociedade (Yamanaka, Paiva e Silva, Zanolli, \& Paiva e Silva, 2010). Isto nem sempre será possível, uma vez que, para que a criança possa ter melhor aproveitamento do implante, diversos fatores estão envolvidos, como grau e causa da deficiência auditiva, idade em que realizou o implante, tempo de privação sonora, frequência na terapia fonoaudiológica especializada, desenvolvimento global da criança, características gerais da criança, e a motivação e envolvimento da família no processo de habilitação/reabilitação da criança. No entanto, alguns pais ficam com grandes expectativas com relação ao desenvolvimento da fala de seus filhos e se desmotivam quando o resultado positivo tão desejado demora a ocorrer (Bevilacqua, Moret \& Costa, 2011). 
É importante também compreender o uso da nomenclatura padrão em relação à perda auditiva. De acordo com a OMS (WHO, 2018), as pessoas que possuem perda auditiva leve a moderada, mas têm parte da audição, são consideradas deficientes auditivas. Já as pessoas que possuem perda auditiva bilateral severa a profunda, cuja audição não é funcional no dia-a-dia e usa a língua de sinais para se comunicar, são surdas. Porém, no contexto social e cultural, existem diversas perspectivas em relação à nomenclatura, questão que será discutida mais a frente. É válido mencionar que, dentre os surdos, existem os que são sinalizantes, que se comunicam através da língua de sinais; os oralizados, que se comunicam através da fala oral e da leitura labial; e os que são bimodais, se comunicando das duas formas, através do Português falado e da Língua de sinais.

\section{2}

\section{A surdez como fenômeno cultural}

Desde o início da humanidade, as pessoas consideradas diferentes da maioria, dos padrões pré-moldados pela sociedade e dos valores culturais de normalidade, são discriminadas. Com os surdos não foi diferente (Honora \& Frizanco, 2009; Skliar, 1998). É importante fazer referência à história desse grupo minoritário, desde a Antiguidade até os dias atuais, para compreendermos a problemática sociocultural da surdez.

$\mathrm{Na}$ Idade Antiga, na Grécia, os surdos eram vistos como incompetentes que, por não possuírem linguagem, não eram capazes de adquirir conhecimento e desenvolver qualquer potencial. Os romanos, que herdaram dos gregos o ideal pela perfeição física, também compreendiam os surdos como seres imperfeitos e os excluíam da sociedade. A concepção da impossibilidade de os surdos desenvolverem a fala era associada ao não desenvolvimento de um raciocínio lógico, o que o tornava um sujeito incapaz diante da sociedade. Dessa forma, esse grupo minoritário não tinha seus direitos legais assegurados, sendo marginalizados, escravizados e, muitas vezes, condenados à morte, vivendo épocas de sofrimento, de privação e de pobreza extrema (Honora \& Frizanco, 2009).

Na Idade Média, a Igreja Católica, baseada na ideia do homem como imagem e semelhança de Deus, considerava os surdos como imperfeitos; também, por não falarem, havia a crença de que não possuíam alma e, por isso, não podiam 
receber os sacramentos, nem ir para o reino de Deus após a morte. Também existiam leis que proibiam os surdos de receberem heranças e de votar, sendo destituídos de todos os direitos dos cidadãos (Honora \& Frizanco, 2009).

Na Idade Moderna, a partir do século XV na Espanha, algumas famílias nobres, preocupadas com a exclusão de seus filhos surdos da sociedade e da Lei, buscavam auxílio com Pedro Ponce de León (1520-1584), um monge beneditino. Ele dedicou-se a ensinar os surdos a ler, escrever, falar, usar o alfabeto manual, aprender as doutrinas da fé católica, sendo reconhecido como um dos precursores no ensino dos surdos. A possibilidade de o filho surdo ser ensinado e falar implicava diretamente no reconhecimento do mesmo como cidadão e, por consequência, no seu direito de receber a fortuna e o título da família (Moura, 2000). A partir desse momento, inicia-se um movimento que visava a permitir gradativamente a integração dos surdos no meio social.

$\mathrm{Na}$ França, posteriormente, iniciou-se importante movimento que possibilitou uma mudança na história da educação de surdos através da língua de sinais na Europa, com repercussões no Brasil. Charles Michel de L'Epée (17121789), um abade francês, ao acreditar no potencial dos surdos desenvolverem uma linguagem, voltou sua atenção para os instruir em sua própria casa. Através de combinações da língua de sinais com a gramática francesa, criou uma metodologia sinalizada denominada de "sinais metódicos". L’Epée fundou, em 1760, a primeira escola pública para os surdos, o Instituto Nacional de Surdos-Mudos, em Paris, treinou inúmeros professores e publicou estudos sobre o ensino dos surdos (Bentes \& Hayashi, 2016).

No Brasil, os surdos só começaram a ter acesso à educação durante o Império, no governo de D. Pedro II que, ao ter um neto surdo, criou a primeira escola de educação de surdos - o Collégio Nacional dos Surdos-Mudos, atualmente chamado de Instituto Nacional de Educação de Surdos (INES) -, em 26 de setembro de 1857, no Rio de Janeiro. Nesta escola, da mistura da língua de sinais francesa com os sistemas já usados pelos surdos de várias regiões do Brasil, surgiu a Libras. A criação desta instituição possibilitou aos surdos não somente o direito a uma escolarização, mas também visibilidade na sociedade (Bentes \& Hayashi, 2016).

No entanto, em 1880, ocorreu o famoso Congresso de Milão, onde foi realizada uma votação proibindo oficialmente a língua dos sinais na educação de surdos. Este evento foi organizado, patrocinado e conduzido por muitos 
especialistas ouvintes, defensores do oralismo puro, sendo os professores surdos a minoria dos participantes. Os ouvintes acreditavam que a língua de sinais atrapalhava o ensino dos surdos que, segundo eles, deveriam aprender a falar (Sá, 1999). Essa proibição deu origem ao que se passou a chamar de método oralista ou oralismo, que perdurou por quase um século (Skliar, 1998), e passou a ser usado como metodologia em muitas escolas, até mesmo no Brasil. No ano de 1911, o atual INES proibiu o uso da língua de sinais na educação dos surdos (Bentes \& Hayashi, 2016). Houve momentos na história da educação de crianças surdas em que professores amarravam as suas mãos para impedir que elas sinalizassem (Skliar, 1998).

Skliar (1998) define oralismo como o conjunto de representações estabelecidas pelos ouvintes que enfatiza a deficiência, a necessidade de normalização e que, consequentemente, desvaloriza o surdo, obrigando-o a agir como se fosse ouvinte, tendo este que oralizar/falar e fazer leitura labial. Essa visão etnocêntrica tem como premissa a identidade ouvinte como superior. Dessa forma, segundo o autor, os surdos passaram a ser representados por uma concepção clínicoterapêutica, que compreende a surdez como uma parte do corpo que apresenta um déficit e tem como foco a incapacidade do sujeito.

Diante dessa perspectiva, entender a surdez apenas como uma deficiência implica a necessidade de tratamento, visando à sua "cura". A "cura" na atualidade, nos casos de crianças que nascem ou que se tornam surdas nos primeiros meses de vida, está relacionada à possibilidade de ouvir, através de intervenções cirúrgicas como o IC ou do uso de AASI, e ao aprendizado da língua oral. Se o surdo puder, através desses recursos, ouvir e/ou aprender a falar o português (no caso do Brasil), estará incluído na sociedade.

Em contrapartida a esse modelo vigente, a concepção socioantropológica postula que a perda da audição não é o elemento principal da surdez. De acordo com Skliar (1998), não se trata de ver o surdo como portador de uma incapacidade, limitando-se a um diagnóstico médico, mas de compreender a surdez como uma diferença. $\mathrm{O}$ autor descreve a surdez como uma experiência visual, apontando que esta experiência não se limita à capacidade de produção e compreensão de uma forma de comunicação ou a um modelo único de processamento cognitivo, mas que se revela em todas as significações e produções deste indivíduo, sendo a forma de o surdo estar no mundo. Assim, mostra-se necessário compreender o surdo como 
aquele que difere do ouvinte não porque não ouve, mas porque desenvolve potencialidades psicológicas e culturais próprias (Behares, 2000).

Atualmente, observa-se um processo de mudança significativa do olhar da sociedade em relação à questão do surdo, à sua língua e cultura. Entretanto, esse é ainda um processo muito lento dentro da sociedade brasileira. Até poucos anos atrás, a Libras era estigmatizada. Somente com a Lei 10.436 de 24 de abril de 2002 e o Decreto 5.626 de dezembro de 2005, esta foi legitimada como língua oficial dos surdos brasileiros, respeitando sua identidade, cultura e seus direitos como cidadãos. As Associações de Surdos ainda lutam para garantir os direitos dos surdos já previstos em leis, mas os resultados dessa luta ainda não são suficientemente satisfatórios para promover as mudanças necessárias em suas vidas.

A falta de conhecimento acerca das capacidades e das potencialidades da pessoa surda pode gerar preconceito na sociedade e na própria família. Compreender o surdo como um indivíduo diferente permite aceitá-lo como ele é, respeitando sua limitação auditiva. Não se trata de ignorar a deficiência, ser surdo é ter uma falta em relação ao padrão ouvinte. Contudo, resumir o surdo a um diagnóstico médico é limitá-lo (Skliar, 1998). A surdez é mais do que um fenômeno médico, é "um fenômeno cultural, com padrões e problemas sociais, emocionais, linguísticos e intelectuais que estão inextricavelmente ligados" (Sacks, 2010, p. 76).

\section{3}

\section{A cultura surda}

O conceito de cultura é complexo e de difícil representação, por apresentar diversas definições. Teremos como base principal para compreender o movimento e a constituição do surdo como fenômeno cultural os estudos de Karin Strobel, autora surda formada em pedagogia e doutora em educação, que propõe um modelo representativo dos surdos como grupo cultural.

Geertz (1989) define cultura como um sistema de significados (sentidos) e de representações simbólicas partilhados por um determinado grupo, que faz parte de suas ações e interações sociais. Relaciona-se a tudo aquilo que caracteriza e torna o grupo único, tais como língua, crenças, hábitos, modos de agir e de vestimenta, por exemplo. De acordo com o autor, para compreender a cultura de determinado grupo, é preciso reconhecer as diferenças do mesmo em suas particularidades. Nesta 
perspectiva, para conhecer a cultura surda, faz-se necessário entender os meios pelos quais o surdo compreende e atua no mundo, levando em consideração o estilo de viver que é próprio de quem utiliza a visão como meio principal de obter conhecimentos (Strobel, 2009).

Strobel (2009) descreve a cultura surda como "o jeito de o sujeito surdo entender o mundo e de modificá-lo a fim de torná-lo acessível e habitável, ajustando-o com as suas percepções visuais, que contribuem para a definição das identidades surdas e das 'almas' das comunidades surdas" (p. 22). Complementando o conceito, a linguística surda Carol Padden (1989) afirma que a cultura surda "é um conjunto de comportamentos aprendidos de um grupo de pessoas que possuem sua própria língua, valores, regras de comportamento e tradições” (p. 5). Desta forma, a língua de sinais, as estratégias do despertador que vibra, a campainha que acende luz, as mensagens de textos, dentre outros, são os marcadores dessa cultura. Atualmente, os estudos voltados para a cultura surda vêm colaborando para uma representação do surdo como sujeito e cultura.

Como forma de afirmação e de legitimação desta cultura, as comunidades surdas fazem uso de seus artefatos culturais que, segundo Strobel (2009), têm como função fornecer informações em relação à cultura de cada indivíduo ou grupo, de todo conteúdo presente na cultura. Incluem desde o que é material, como a vestimenta, as artes e utensílios, até o que é imaterial, como os valores e normas que determinam a forma de se relacionar individual e coletivamente. A autora identifica oito principais: experiência visual, desenvolvimento linguístico, família, literatura surda, vida social e esportiva, artes visuais, políticas e materiais.

A experiência visual é um dos principais artefatos culturais, e consiste em utilizar a visão em substituição à audição como meio de comunicação (Strobel, 2009). Corroborando com a autora, Skliar (1998) elucida que os surdos percebem o mundo e fazem contato com ele através de seus olhos, sendo esta forma que os define e os diferencia. Um segundo artefato importante é o linguístico, representado pela língua de sinais, aspecto fundamental da cultura surda. A língua de sinais constitui a forma de comunicação que melhor capta as experiências visuais dos surdos e permite o acesso às informações, ao conhecimento e, por conseguinte, à construção da sua identidade. É um dos meios que permite aos surdos a comunicação entre si e com os ouvintes (Strobel, 2009). 
A família é mencionada pela autora como outro aspecto marcante da cultura surda, uma vez que tem importante papel na constituição da identidade e na comunicação dos surdos. Quadros (2008) afirma que, quando um surdo pertence a uma família surda, o processo de transmissão da cultura surda ocorre de forma espontânea e natural. Isto acontece devido ao fato de a língua utilizada ser a mesma. A criança surda está integrada e participa das conversas em todo momento, tendo, assim, a possibilidade de receber, assimilar, categorizar e dar sentido às informações. No entanto, quando pertence a uma família ouvinte, Strobel (2009) afirma que é possível perceber insuficiências e bloqueios na comunicação, na compreensão e na apreensão do mundo e de sua própria cultura. Devido à ausência de uma língua em comum, a criança surda é apenas uma observadora de conversas e diálogos. Por isso a importância de os pais aprenderem e ensinarem a língua de sinais, bem como propiciarem contato com outros surdos. Além disso, Strobel (2009) pontua que a família ouvinte é o primeiro núcleo da sociedade que enfatiza o discurso da medicalização/normalização para o surdo.

A literatura surda também é um artefato relevante, e está presente em toda a trajetória dos surdos. Este artefato se refere às experiências do povo surdo que, através de histórias produzidas por e para surdos, compartilham as dificuldades e/ou vitórias de situações vivenciadas, narram ações de importantes líderes e militantes surdos e também valorizam e afirmam a identidade surda. Essas experiências são representadas através de textos como poesias, piadas, histórias, literatura infantil, lendas, contos, romances e fábulas, dentre outros gêneros textuais, que podem ser criados, adaptados ou traduzidos. São marcados pela língua de sinais e por traços que representam a identidade e a cultura surda. É por meio da literatura que a história dos surdos se perpetua (Strobel, 2009). D. Carvalho (2014) enfatiza a importância da literatura surda como agente formador e conscientizador da comunidade surda.

A vida social e esportiva dos surdos compreende os acontecimentos culturais, como casamentos entre os surdos, as festas, os lazeres, as atividades nas associações de surdos, os eventos esportivos, dentre outros. Alguns rituais e costumes dos surdos também fazem parte desse artefato, como batizar com um sinal pessoal os nomes de seus membros. O surdo, após conversar com a pessoa, tendo como referência uma característica física, a profissão, comportamentos marcantes, 
manias ou até mesmo a letra inicial do seu nome, atribui um sinal de identificação pessoal, não podendo mais ser alterado (Strobel, 2009).

As artes visuais, isto é, as criações artísticas por meio das quais os surdos manifestam suas emoções, histórias, subjetividades e cultura, também compõem os artefatos culturais. A política também é um artefato fundamental, pois, através dos movimentos e das associações, os surdos estruturam as lutas pelos seus direitos. E, por último, temos os artefatos materiais, resultantes da adaptação e da transformação de objetos para acessibilidade no dia-a-dia do surdo, como as campainhas luminosas, babás eletrônicas com luzes, telefones adaptados (TDD), despertador que vibra e closed caption, por exemplo. Como podemos perceber, os artefatos culturais são elementos fundamentais para os surdos. Eles representam a cultura surda, mostrando a especificidade do surdo ser e interagir com o mundo.

Dentro dessa temática, cabe ainda a distinção entre povo surdo e comunidade surda. O termo "comunidade" é usado para se referir a um agrupamento de pessoas que vive dentro de uma mesma área geográfica e compartilha interesses comuns e partilham condições gerais de vida. Desta forma, de acordo Strobel (2009), a comunidade surda é composta não apenas por sujeitos surdos, mas também por familiares, professores, intérpretes e amigos ouvintes que se identificam com a luta deste povo. Enquanto "povo surdo" é o grupo de sujeitos surdos que tem costumes, história, tradições em comuns e pertencentes às mesmas peculiaridades, isto é, apreendem o mundo através da visão.

A cultura dos surdos é permeada por lutas e movimentos baseados na inclusão dos surdos dentro da sociedade ouvinte. A comunidade surda se uniu contra as práticas ouvintistas que não os reconheciam enquanto cultura (Strobel, 2009). Diante da necessidade de um espaço para os surdos, as organizações, as associações e a federação de surdos tiveram importante papel na luta pela defesa de políticas voltadas para o reconhecimento da cultura surda e dos direitos básicos desse grupo.

Podemos pensar, de acordo com Strobel (2009), que a existência do termo "cultura surda" implica de forma inerente a noção da diferença, que vai além da deficiência, reafirmando que a maneira como os surdos apreendem o mundo é diferente da maneira como os ouvintes o fazem. Isto está intimamente relacionado à definição de sua identidade. Diante disso, é necessária uma ressignificação da surdez pela sociedade e uma nova postura perante os surdos. Conforme afirma a 
autora, não respeitar as peculiaridades dos surdos os impossibilita de manifestar sua cultura, o que fere os seus direitos como cidadãos.

O desconhecimento das particularidades da surdez, da cultura surda e das capacidades e potencialidades do surdo pode gerar dificuldades na aceitação desse diagnóstico. Tendo em vista que a maior parte das famílias de surdos é formada por ouvintes (Felipe, 2009), a seguir buscaremos refletir sobre como se constroem as relações familiares entre pais ouvintes e filhos surdos diante do diagnóstico inesperado de surdez e o desconhecimento dessa condição. 


\title{
3 \\ Tornando-se pais de filhos surdos
}

\begin{abstract}
"Em nosso coração, bem no âmago do nosso ser, todos ansiamos por ter um filho que seja um atestado eloquente de nosso valor como pessoas. Um filho que irá demonstrar ao mundo a grandeza de nossa condição de pais." (Maria Amélia Vampré Xavier")
\end{abstract}

Este capítulo tem como objetivo compreender a parentalidade com filhos surdos. Incialmente, serão discutidas questões referentes ao nascimento de um bebê diferente do esperado, particularmente nos primeiros momentos após o diagnóstico. A perda do filho idealizado e a adaptação/aproximação com o filho surdo exige um trabalho de elaboração de luto, processo que será abordado em seguida. Na parte final, abordaremos as particularidades da interação de pais ouvintes com um filho surdo.

\section{1 \\ O nascimento de um filho inesperado}

A maioria das crianças surdas são filhas de pais ouvintes, dos quais a maior parte não tem histórico de surdez na família e, por vezes, nunca tiveram contato com uma pessoa surda (Felipe, 2009). Desconhecem, portanto, as particularidades da surdez e, na maioria das vezes, percebem-na apenas como uma deficiência (Stelling, Stelling, Torres \& Castro, 2014). Geralmente, os pais são surpreendidos com tal situação, totalmente inesperada e distante da planejada, pois o filho surdo não foi o filho que idealizaram.

A parentalidade, segundo Houzel (2004), centra-se na possibilidade de os genitores tornarem-se pais e mães, através de um processo complexo que implica níveis conscientes e inconscientes. A parentalidade se constrói e se transforma ao longo do ciclo vital. Corroborando com o autor, Zornig (2010) assinala que a parentalidade não se refere apenas ao exercício efetivo do ser pai ou do ser mãe

\footnotetext{
1 Maria Amélia Vampré Xavier, pioneira na luta pela inclusão das pessoas com deficiência intelectual e múltipla. Fundadora da Associação de Pais Amigos dos Excepcionais (Apae) de São Paulo na década de 1960 e autora de diversas obras, entre elas: "O Outro lado do Arco-Íris - Meu Filho Ricardo" e "Enfrentando Desafios".
} 
após o nascimento dos filhos, mas a um processo que começa bem antes da gestação, baseado nas identificações feitas na infância e que podem influenciar os modos de exercer a parentalidade.

Este processo se inicia com o desejo e projeto de ter um filho, sendo vivido de forma intensa durante a gestação e ganhando nova dimensão com a chegada do bebê. Os futuros pais precisam criar um espaço psíquico para a chegada de um terceiro. Esse espaço é uma cocriação, formada pelas vivências, expectativas e disponibilidade afetiva dos pais (Lebovici, 2004). Stern (1997) enfatiza a dimensão simbólica do acesso à parentalidade, sugerindo que o nascimento de um filho provoca transformações profundas e irreversíveis no psiquismo de cada um dos pais. Essas mudanças ocorrem em função das projeções e das representações dos pais sobre o bebê e, também, da transformação que o bebê real gera nas interações entre ele e seus pais (Zornig, 2010).

O bebê está representado no psiquismo da mãe e do pai antes mesmo de sua concepção. A pré-história da criança se inicia na história individual de cada um dos pais. Desde a gravidez, cada genitor reatualiza fantasias da própria infância, envolvendo o cuidado parental que tiveram. As identificações feitas na infância influenciam e determinam a forma como cada um exercitará a parentalidade (Zornig, 2010). J. Carvalho (2000) pontua que, antes mesmo do nascimento da criança, ela é pensada, falada e desejada. O filho existe no imaginário dos pais, tendo um lugar na família, pré-determinado, e este é carregado de expectativas, desejos e esperanças em relação ao novo ser. Nas fantasias parentais, o nascimento do filho possibilita a continuidade da espécie humana, pois recaem sobre ele os valores, as crenças e as ideologias próprias da família e da cultura a que pertencem.

Freud (1914/1996a), em seu estudo "Introdução ao Narcisismo", contribuiu para a compreensão da parentalidade. $\mathrm{O}$ autor propõe que o encantamento dos pais em relação aos filhos não é nada mais que um retorno e reprodução a seu próprio narcisismo. Existiria nos pais o desejo de que "Sua Majestade, o bebê" concretizasse seus próprios sonhos perdidos, reparasse as feridas narcísicas. Dessa forma, a concepção de uma criança poderia mobilizar nos pais o desejo de ter um bebê perfeito como eles próprios desejariam ter sido.

Corroborando com a temática, Lebovici (1987) propõe cinco tipos de representações parentais sobre o bebê: (1) o bebê fantasmático, relacionado à criança que os pais individualmente têm em mente a partir de sua própria história; 
(2) o bebê imaginário, uma representação mais consciente que pertence ao casal de como será essa criança - características físicas, por exemplo; (3) o bebê narcísico, relacionado à representação dos ideais de como o filho irá sucedê-los; (4) o bebê cultural, que se refere a um grupo de representações coletivas de uma determinada sociedade em um determinado momento; e (5) o bebê real, na sua corporeidade, que confronta o bebê imaginário. Essas diferentes representações se misturam e levam a uma idealização de como será a criança.

O bebê idealizado pelos pais ao longo da gravidez é sempre diferente da criança que vem ao mundo. O narcisismo dos pais dá a ilusão do poder de produzir um filho perfeito, o que é confrontado a partir do nascimento. De acordo com Lebovici (1987), “a criança encontra seu lugar na família a partir da confrontação do bebê imaginário com o bebê real e a adaptação dos pais às necessidades do recém-nascido" (p. 32). De forma a aceitar o bebê real e se vincular a ele, os pais vivenciam um processo natural de luto. A elaboração da perda do bebê idealizado e a adaptação/aproximação ao bebê real é uma crise necessária em qualquer nascimento, constituindo o processo de construção da parentalidade (TravassosRodriguez \& Féres-Carneiro, 2012).

Com a confirmação do diagnóstico de surdez, atestando o nascimento de uma criança muito diferente da idealizada pelos pais, eles apresentam dificuldades em elaborar esse luto, tornando difícil o investimento no filho que nasceu (Asano, Neme \& Yamada, 2010; Sá \& Rabinovich, 2006). Com base nos estudos de Góes (2006) sobre os conflitos que emergem nos pais após o nascimento de uma criança com deficiência, é possível pensar que os pais ouvintes não conseguem se (re)conhecer nessa criança que chegou com uma "falha", sendo difícil para eles encontrar vestígios ou marcas que se ajustem às representações do que haviam previamente estabelecido em relação ao bebê.

Asano, Neme e Yamada (2010) afirmam que o nascimento de um filho surdo é uma situação imprevista para os progenitores, ocasionando uma ruptura no narcisismo dos mesmos e uma perda do ideal projetado nesta criança. Outros estudos realizados sobre a reação dos pais, imediatamente após diagnóstico de surdez, demonstram que o mesmo parece provocar uma situação de choque, caracterizada por um turbilhão de sentimentos - tristeza, culpa, medo, angústia, vergonha, fracasso e frustração -, e recusa em aceitar o diagnóstico (Trindade, 2017; Yamada, Moretti, Prado \& Bevilacqua, 2014). 


\section{2}

\section{A confirmação do diagnóstico de surdez e o luto pelo filho perfeito}

A surdez, por não ser aparente, acaba passando despercebida. Quando não é diagnosticada no exame Emissões Otoacústicas (EOA), ou quando este exame não é feito, um problema que pode ocorrer é a suspeita tardia por parte dos pais e dos profissionais de saúde. Os pais começam a suspeitar de que algo está errado um pouco mais tarde, devido à responsividade do bebê. O bebê surdo não apresenta muitas diferenças, ele vivencia emoções, chora e balbucia de modo semelhante ao bebê cuja audição não está prejudicada (Trindade, 2017).

Ao estudar as reações dos pais após a confirmação do diagnóstico, Vieira, Bevilacqua, Ferreira e Dupas (2012) apontam que, em um primeiro momento, os pais não acreditam, apresentam dúvidas e relutam ao pensar que alguma coisa pode estar errada. Corroborando com os autores, Luterman (1979) e Silva, Zanolli e Pereira (2008) afirmam que é normal que os pais apresentem mecanismos de defesa psicológicos, como a negação, por meio da qual eles desconsideram a percepção do fato de a criança não responder à sua voz; ou como a racionalização, que leva os pais a buscarem explicações para fatos observados, como "a criança ouve o que quer ouvir" ou "a minha família tem histórico de falar tarde".

As pesquisas de Silva, Pereira e Zanolli (2012) e Silva, Zanolli e Pereira (2008) demonstram que os pais começam inconscientemente a testar a criança, o que tem pouca eficácia, devido à audição residual existente, já que raramente a surdez é total. Quanto maior o resíduo auditivo, mais difícil de constatar que a criança não está ouvindo. Muitas vezes, os pais acreditam que eles escutam, pois reagem à batida de portas ou a estímulos sonoros produzidos por pessoas e objetos no ambiente. Na verdade, isso ocorre também porque, como são extremamente visuais, o que lhes chama a atenção para o ocorrido é o movimento produzido à sua volta, e não o barulho em si. Do mesmo modo, quando são produzidas vibrações no chão ou em objetos próximos, eles podem senti-las pelo tato, confundindo os pais. Assim, a resposta da criança a sons mais fortes e graves, à vibração, ao estímulo visual e/ou à pressão do ar criada pela batida de objetos, acaba mascarando a perda auditiva. Isto enfraquece a suspeita e conduz à postergação do encaminhamento ao 
otorrinolaringologista, o que pode prejudicar o desenvolvimento da criança e de suas habilidades.

No Brasil, devido à desigualdade social e à precariedade no sistema de saúde, nem todas as famílias têm acesso ao teste que diagnostica a perda auditiva (Alvarenga, Gadret, Araujo \& Bevilacqua, 2012; Marchand, Rech, Benvenutti, Soldera \& Machado, 2016). Diante disso, estudos demonstram que a suspeita da surdez se dá tardiamente, quando os pais percebem que a criança não começou a falar as primeiras palavras. Geralmente a mãe, a vó ou pessoas mais próximas da criança é que observam (Silva, Pereira \& Zanolli, 2012; Trindade, 2017; Vieira, Bevilacqua, Ferreira \& Dupas, 2012). Entretanto, ressalta-se a importância do diagnóstico precoce. O ideal é que a confirmação da surdez ocorra até os três meses de vida, pois dentro desse período é possível proporcionar melhoras relevantes nas condições de comunicação e de socialização do surdo em relação à sua família (Santos, Lima \& Rossi, 2003).

A confirmação do diagnóstico de surdez para os pais ouvintes, atestando o nascimento de um filho totalmente diferente do esperado e com necessidades específicas, é desestruturadora e faz com que estes enfrentem um desafio único. Os pais podem desenvolver sentimentos semelhantes aos vivenciados em um processo de luto (Asano, Neme \& Yamada, 2010; Góes, 2006; Sá \& Rabinovich, 2006; Stelling, Stelling, Torres \& Castro, 2014; Vieira, Bevilacqua, Ferreira \& Dupas, 2012). O termo "luto" tem origem do latim lucto, que significa sentimento de pesar pela morte de alguém. O luto é definido como a expressão de sentimentos diante de uma perda. A definição da experiência de luto é bastante complexa, uma vez que, a depender da cultura, do meio familiar e do contexto da própria perda, cada pessoa a vivencia de forma particular. É um processo extremamente subjetivo, não havendo uma forma certa ou errada de viver essa perda (Franco, 2002). Diante disso, para uma melhor compreensão desse processo, considera-se importante abordar algumas perspectivas e modelos que têm sido evidenciados neste campo.

Freud (1917[1915]/1996b), em "Luto e Melancolia", descreve o luto como uma reação diante da morte ou da perda de um ser amado. Um processo gradativo e doloroso que pode ser superado com o passar do tempo, conforme a libido investida no objeto perdido seja desligada e redirecionada a outros investimentos. No entanto, durante esse processo, o enlutado poderia apresentar sentimentos de tristeza e pesar, desinteresse pelo mundo externo, perda da capacidade de amar e 
afastamento de atividades, precisando de tempo até a restauração do equilíbrio psíquico.

Outros autores delinearam uma sequência de reações esperadas do processo de luto, referido por fases pelas quais as pessoas passam quando perdem alguém muito significativo (Kübler-Ross, 1969/1998; Bowlby, 1969/2002; Parkes, 1998; Worden, 1998). Dentre eles, destaca-se John Bowlby (1969/2002), que descreve o luto como consequência à perda de um vínculo afetivo significativo, rompendo assim com um significado de proteção e segurança na vida. Caracteriza as reações de sofrimento advindas da perda desse vínculo em quatro fases: entorpecimento, anseio e busca, desorganização e desespero e reorganização. Essas fases ocorrem de forma flexível quanto ao tempo, podem oscilar entre duas delas ao longo do processo, e devem ser compreendidas como padrões de comportamento, e não como fases cronológicas.

A primeira fase é denominada de entorpecimento, o choque inicial, onde o indivíduo tem dificuldades em reconhecer a perda. Essa fase pode durar horas e até semanas. A segunda fase, denominada de anseio e busca, seria a procura pela figura que foi perdida. É marcada pela esperança de reaver o ente querido. O enlutado percorre lugares onde costumava encontrar essa pessoa, pode sonhar com ela e sentir sua presença concreta, por exemplo. A terceira fase, desorganização e desespero, é caracterizada pela percepção real de que a perda é permanente. Em decorrência, o enlutado pode apresentar desmotivação pela vida, angústia, depressão, ansiedade e isolamento social. A quarta e última fase, a reorganização, ocorre quando há adaptação gradual à perda e um retorno ao funcionamento normal da vida. Apesar do desejo de manter a proximidade com o ente querido, o enlutado percebe a necessidade de reconstrução da vida.

Elizabeth Kübler-Ross (1969/1998), autora da famosa obra "Sobre a morte e o morrer", também propõe estágios pelos quais passam as pessoas no processo de luto, sendo eles: negação, raiva, barganha, depressão e aceitação. Na negação, ao saber sobre a perda, a primeira reação, geralmente, é não acreditar no ocorrido. A negação é uma defesa temporária ao estado de choque, do qual o enlutado vai gradativamente se recuperando. A segunda fase é a raiva, que pode ser direcionada para qualquer coisa ou pessoa, como para a equipe médica que não conseguiu salvar aquele que morreu, ou ao próprio enlutado ou para Deus, por exemplo. A pessoa enlutada, nesse estágio, queixa-se de tudo. É importante ressaltar que o alívio 
proveniente ao externalizar a raiva contribui para a elaboração do luto. A terceira fase é a barganha, uma tentativa de o enlutado negociar os seus medos diante da perda com figuras que, de acordo com suas crenças, têm o poder para intervir nessa situação de morte. A quarta fase é a depressão, que se caracteriza pela conscientização da perda, e o enlutado pode se isolar e sentir tristeza e solidão profunda. Esta fase não deve ser vista como um estado patológico, que necessite de intervenção medicamentosa, mas como um momento de preparação que serve como facilitador para a aceitação. A quinta e última fase é a aceitação, caracterizada pela aceitação da realidade da perda. A autora também ressalta que essas fases não ocorrem de forma sequencial e estática e devem ser entendidas como manifestações de adaptação ativa do indivíduo diante de uma perda.

Os primeiros estudos sobre o luto consideravam uma proposta de desligamento com a pessoa falecida, dando ênfase à expressão dos sentimentos. Diante disso, o conceito de luto é comumente associado apenas à noção de morte. No entanto, este não se limita unicamente à perda de alguém; o que provoca o luto é a valorização afetiva que se atribui ao objeto perdido, seja ele real ou simbólico (Grinberg, 2000). Nesta perspectiva, podemos vivenciar um luto pela perda de uma relação afetiva, de um emprego ou de uma mudança de cidade, por exemplo.

É possível identificar o processo de luto também nas famílias ouvintes quando descobrem a surdez dos filhos. Amaral (1995) afirma que os pais ouvintes apresentam um estado de pesar e luto pelo filho desejado e idealizado. O processo de luto se constitui justamente a partir da perda dos planos, sonhos e projetos que tinham para a criança que não nasceu "normal", "saudável”. As expectativas e os sonhos que os pais tinham para o filho são rompidos com a confirmação do diagnóstico e os pais reagem com frustração a esta situação, se caracterizando um processo delicado de luto (Asano, Neme \& Yamada, 2010; Sá \& Rabinovich, 2006; Silva, Zanolli \& Pereira, 2008; Vieira, Bevilacqua, Ferreira \& Dupas, 2012).

Luterman (1979) e Luterman, Kurtzer-White \& Seewald (1999), traçando um paralelo com Kübler-Ross (1969/1998), descrevem o processo de ajustamento da família após receber o diagnóstico de surdez, que compreende as fases de: choque, reconhecimento, negação, adaptação-aceitação e construção ativa ou adaptação. As fases apresentadas dizem respeito à reação da família à perda do bebê idealizado, marcadas por sentimento de luto pela morte simbólica desse filho perfeito, da criança saudável. Inicialmente, na fase do choque, o momento em que 
os pais sofrem com o impacto da descoberta da surdez, há uma estagnação de ações e sentimentos confusos, intensos e contraditórios por não se saber ao certo o que é a surdez, mas por já se saber que o filho é surdo.

Quando os pais percebem a severidade e a permanência da surdez, reconhecem as dificuldades da situação e começam a admiti-la. No início, os pais podem sentir-se decepcionados, frustrados, revoltados, ansiosos e angustiados. Sofrem ao perceber suas dificuldades em se vincular ao filho, sentindo-se oprimidos e inadequados para a tarefa de criar um filho surdo, o que pode levá-los a uma reação de pânico. Outros sentimentos podem emergir nesse estágio, como raiva, depressão, culpa e superproteção. Essas são as características da fase de reconhecimento da surdez (Luterman, 1979; Luterman, Kurtzer-White \& Seewald, 1999).

Um período de reação defensiva é comumente visto nos pais, fase identificada como negação (Silva, Pereira \& Zanolli, 2008). Normalmente, neste estágio, os pais embarcam em uma aventura de "corrida aos médicos" em busca de diagnósticos otimistas, procurando mais uma opinião. Em consequência, ocorre uma incessante tentativa de recuperação da perda auditiva. Em um primeiro momento, a expectativa dos pais recai sobre os AASI e sobre o IC, como se estes fossem corrigir a audição do filho. No entanto, nem todos os usuários apresentam ganhos significativos, e muitos pais se desapontam ao constatar que apenas o uso destes dispositivos tecnológicos não realiza o desejo de o filho ouvir e falar como um ouvinte (Longato-Morais, Prado \& Yamada, 2017; Mahl, Nóro, Zanini, Kessler \& Biaggio, 2013; Silva, Pereira \& Zanolli, 2012; Silva, Zanolli \& Pereira, 2008).

Logo que os pais começam a enxergar a surdez por meio de um novo olhar, pois já receberam mais informações e esclarecimentos pelos profissionais e até por outros pais, passam a admitir a surdez do filho e as suas limitações. Inicia-se, então, a fase de adaptação-aceitação. É um período durante o qual ocorre a diminuição da ansiedade e das reações emocionais mais intensas. Os pais começam a se aproximar mais do bebê e também a buscar mais informações sobre a surdez (Luterman, 1979; Luterman, Kurtzer-White \& Seewald, 1999).

Por fim, temos a fase da construção ativa ou adaptação. Representa o final do processo de luto. Durante este período, ocorre elaboração da culpa por parte dos pais, que reexaminam seus valores e reestruturam suas vidas, adaptando-se à surdez do filho. Segundo Luterman (1979) e Luterman, Kurtzer-White \& Seewald (1999), 
tal representação em fases é uma generalização das diferentes reações da família, não devendo ser pensadas de forma sequencial e estática, como dito anteriormente, e nem universal.

Contudo, os estudos atuais sobre o luto apontam novas possibilidades e permitem uma compreensão mais dinâmica desse processo (Neimeyer, 2001; Stroebe \& Schut, 1999; Franco, 2002). O modelo do Processo Dual do luto, proposto por Stroebe e Schut (1999), sugere um processo dinâmico e regulador de elaboração do luto através de momentos de oscilação entre o enfrentamento orientado para a perda e o enfrentamento orientado para a restauração. Significa que este processo não é normativo e nem linear; mas que existem momentos em que o enlutado está mais voltado para a perda, tendo que lidar com a tristeza e com o pesar, e outros em que está voltado para a restauração, para o ajustamento da vida após a perda, tendo que dar conta das tarefas, e buscando a reconstrução de uma nova identidade. Os autores esclarecem que essa oscilação é um processo regulador, saudável e necessário ao longo do processo de elaboração do luto e que continua através do tempo.

Neimeyer (2001) ressalta a importância do processo de construção de significados atribuídos à perda do enlutado por meio da narrativa. Poder desenvolver uma narrativa coerente do significado da vida e da morte do falecido permite ao enlutado entender a perda e o luto, o que pode reduzir o sofrimento, além de reconstruir sua identidade e restaurar o significado da vida. Diante dessa perspectiva, é interessante refletir acerca do significado atribuído pelos pais ao nascimento de um filho surdo como facilitador do processo de luto. A pesquisa de Oliveira, Silva, Frota, Pinto, Frota e Sá (2008) sobre a experiência de mães cuidadoras de filhos deficientes aponta que, em seus relatos, elas se sentiam escolhidas por Deus para cumprir a missão que lhes foi confiada, compreendendo a deficiência do filho como uma dádiva e, a partir disso, sentindo-se capacitadas para essa missão. A espiritualidade, nesta situação, forneceu respostas, significados à deficiência e consolo diante do novo desafio. A forma pela qual os pais compreendem o diagnóstico da criança e atribuem significado a este é fundamental para a aceitação da criança real e para o processo de adaptação e ajustamento da família (Petean \& Murata, 2000).

Buscaglia (2002) ressalta que não existe uma forma única de a família encarar esta situação inesperada do nascimento de um filho com deficiência, e que 
existem diferentes padrões de reação às emoções. Em um extremo haverá os pais que imediatamente aceitam a dificuldade como algo inevitável, de maneira realista e equilibrada, buscando novos modos para lidar com a situação. No outro, os pais que passarão a vida se lamentando, manifestando autopiedade e em um isolamento autoimposto. No entanto, segundo o autor, a maior parte dos pais encontrará um equilíbrio entre os extremos, podendo oscilar entre um e outro, corroborando a proposta do Modelo Dual, que afirma ser esse um movimento saudável para a elaboração do luto.

O luto, portanto, é um processo necessário para que a pessoa possa se reconstruir e se reorganizar diante de uma perda significativa. Worden (1998) destaca a importância da vivência do processo de enlutamento para que a dor da perda não fique reprimida. Brunhara e Petean (1999) também sublinham a necessidade de os pais poderem se enlutar, chorar a perda do filho idealizado e se permitirem um tempo para a vivência desse luto, para que possam estabelecer um vínculo com o filho real.

A aceitação de um filho surdo exige reorganização dos valores, dos objetivos da família e ressignificação da experiência da parentalidade. É um momento em que existe o risco de transtornos emocionais, mas também a possibilidade de crescimento, fortalecimento e maturidade, tanto para os indivíduos envolvidos como para os vínculos estabelecidos (Amiralian, 1986). Portanto, o nascimento de um filho surdo demanda um processo de reorganização individual, conjugal e familiar (Asano, Neme \& Yamada, 2010).

\section{3}

\section{Aspectos relevantes da parentalidade com um filho surdo}

O nascimento de um bebê surdo em uma família ouvinte pode trazer sentimentos e situações conflitantes que acarretarão consequências para a parentalidade. A dificuldade no estabelecimento do vínculo afetivo entre os pais e o filho surdo é a maior delas. Rossi (2003) afirma que o nascimento de um bebê surdo, sem um diagnóstico pré e perinatal, caracteriza-se por uma situação particular. A interação inicial dos pais ouvintes com o bebê surdo é marcada por afetividade e responsividade. No entanto, a autora afirma que, com o impacto do diagnóstico, o vínculo dos pais com a criança é modificado radicalmente. Os 
sentimentos de tristeza e de frustração vivenciados pelos pais nesse momento pós diagnóstico podem se desdobrar em uma dificuldade na experiência de intimidade com a criança, se refletindo no modo de cuidar, de conversar e responder aos estímulos do filho. Os pais ficam pouco disponíveis para exercer sua parentalidade, o que acarreta em descompasso na interação (Yamada, Moretti, Prado \& Bevilacqua, 2014; Yamada \& Valle, 2014).

Associado a estes sentimentos, muitas vezes os pais sentem culpa por gerarem um filho imperfeito, especialmente a mãe. Existem relatos de mães que adoeceram após a descoberta da deficiência, que desenvolveram quadros depressivos e ideação suicida (Medeiros \& Salomão, 2012). A culpa advém também, muitas vezes, do sentimento de rejeição dos pais pelos filhos. Bittencourt e Montagnoli (2007) esclarecem que os pais podem vivenciar a surdez como um fardo e que esse sentimento pode ser intensificado pela dependência da criança surda em relação aos pais, gerando mais estresse e sobrecarga devido aos cuidados especiais que devem dedicar ao filho.

Após o diagnóstico, é comum que os pais se isolem e reduzam tanto o número de relações sociais como também a qualidade das atividades de lazer (Oliveira, Simionato, Negrelli \& Marcon, 2004). A sociedade apresenta muitas dificuldades em lidar com pessoas diferentes, e ainda existem muitas formas de preconceito às pessoas surdas. Diante disso, os pais justificam o comportamento de evitação devido ao receio de expor a criança a situações de incompreensão, não aceitação e até mesmo de rejeição (Barbosa, Chaud \& Gomes, 2008; Bittencourt \& Montagnoli, 2007; Trindade, 2017). Assim, eles assumem as mesmas atitudes encontradas na sociedade e o padrão de normalidade imposto, sendo possível identificar o sentimento de vergonha por ter um filho diferente do esperado (Barbosa, Chaud \& Gomes, 2008). Por outro lado, Bittencourt \& Montagnoli (2007) propõem que os pais atribuem parte de seu sofrimento à discriminação e ao preconceito advindos da sociedade como uma forma de aliviarem seus conflitos relacionados à culpa e à vergonha pela não aceitação do filho surdo.

Ao investigarem o significado da surdez do filho para os pais ouvintes, Canho, Neme e Yamada (2006) constataram um movimento dos pais de minimizar a perda auditiva ou de normalizá-la. Os pais ressaltam as potencialidades e qualidades do filho, considerando a criança normal em várias áreas do seu desenvolvimento; e também comparam a surdez a outras deficiências que julgam 
ser piores, minimizando a real dimensão da perda auditiva. O sofrimento dos pais se manifesta através da negação da condição auditiva do filho. Silva, Zanolli e Pereira (2008) descrevem que esse mecanismo de defesa aparece como forma de atenuar o sofrimento e facilitar a aceitação da surdez.

Por outro lado, é comum observar superproteção e superinvestimento dos pais com o filho surdo, como uma tentativa de ajudar o filho a superar os obstáculos e as limitações da surdez (Augusto \& Chacon, 2011). No entanto, isso resulta em maximização da deficiência e maior dependência dos cuidados parentais. Frequentemente, esse comportamento tem por motivação, mesmo que de forma inconsciente, tornar-se indispensável para o filho, podendo ainda confluir em uma relação de dependência mútua (Oliveira \& Poletto, 2015).

Há também medo e insegurança dos pais acerca do futuro do filho (Oliveira, Cúnico, Cunha, Kruel \& Tochetto, 2013). Os pais com filhos deficientes manifestam preocupação constante em relação ao desenvolvimento, ao sucesso profissional, à aceitação social e à independência financeira dos filhos (Sá \& Rabinovich, 2006). Além disso, mostram-se apreensivos frente a um possível impedimento de cuidar do filho caso fiquem doentes ou quando envelhecerem, e também se vierem a falecer (Oliveira \& Poletto, 2015). Outro ponto importante em relação às expectativas quanto ao futuro é a esperança da possibilidade de melhora ou da cura dos filhos. Segundo Brunhara e Petean (1999), esse sentimento mostrase como uma necessidade dos pais, e está presente independentemente do tipo de deficiência, inclusive quando eles têm consciência da gravidade do quadro ou da remota possibilidade de recuperação. Todos esses fatores geram intenso estresse para os pais, principalmente quando desconhecem as particularidades da surdez.

Somado a tudo isso, os pais sentem-se sobrecarregados pelo fato de terem que decidir constantemente sobre os diversos programas de educação existentes, terapias, os métodos e modalidades de comunicação e se recorrem ou não aos recursos tecnológicos, gerando um excessivo estresse para os membros do casal (Dias, Rocha, Pedroso \& Caporali, 2001). Ademais, outros fatores também podem influenciar o estresse parental, como a baixa condição econômica, a insuficiente rede de apoio, os aborrecimentos diários associados à parentalidade, as comorbidades associadas à surdez e o atraso no desenvolvimento da linguagem da criança (Oliveira, Cúnico, Cunha, Kruel \& Tochetto, 2013). 
Com relação aos papéis parentais, na prática clínica, assim como na revisão da literatura, é possível observar a presença marcante da mãe e os modos peculiares com que genitores masculinos e femininos lidam com o diagnóstico e as necessidades de reabilitação do filho surdo. De acordo com os estudos de KurtzerWhite e Luterman (2003) e Brito e Dessen (1999), a surdez de um filho pode exacerbar as diferenças dos papéis parentais no funcionamento familiar: a mãe aumenta suas responsabilidades com os cuidados da criança e o pai dedica-se ao provimento de recursos. Enquanto o envolvimento do pai com a criança tende a decrescer com o tempo, a responsabilidade da mãe tende a aumentar.

Corroborando esses resultados, Yamada e Valle (2014) apontam a mãe como o principal suporte dos filhos surdos e assinalam que, geralmente, são elas que ficam em casa assumindo as inúmeras responsabilidades do lar, de assistência e cuidado com o filho, e são as que mais se envolvem no processo de reabilitação deste. As mães também demonstram mais interesse em mediar a comunicação dos filhos com outros familiares e aprender a língua de sinais (Paula \& Pereira, 2014). No entanto, esse cenário pode gerar sobrecarga mental e física para as mães, resultando em estresse e isolamento em relação aos demais familiares, principalmente ao marido (Yamada \& Valle, 2014). As reações do pai também impactam nos outros membros da família, especialmente na mãe. Como forma de evitar frustação, os pais tendem a afastar de si o sofrimento, diminuindo o seu contato familiar, o que pode resultar em divórcio ou mesmo no abandono da família (Brito \& Dessen, 1999).

Diversos estudos constataram o predomínio de vivências emocionais negativas, tanto de pais, como de mães, marcadas por sentimentos ambivalentes em relação ao filho e pela dificuldade em aceitar a surdez, com negação, culpa e tentativa de melhorar o desempenho de seu filho para superar os limites (Yamada, Moretti, Prado \& Bevilacqua, 2014; Canho, Neme \& Yamada, 2006; Bittencourt \& Montagnoli, 2007). Esses fatores culminam em um distanciamento entre a criança e seus pais e podem afetar o desenvolvimento da criança. Diante disso, um dos grandes desafios nos primeiros anos de vida de uma criança surda será o estabelecimento de relações afetivas seguras. Nesse sentido, cabe pensar que as principais dificuldades enfrentadas pela família referem-se à comunicação, uma vez que, de acordo com Neuber, Valle e Palamin (2008), essa é determinante para a 
afetividade e a integração familiar, possibilitando as relações afetivas entre a criança surda e seus pais.

Um importante aspecto da interação e do vínculo entre os bebês surdos e seus pais é sua função como elemento constituinte do processo de aquisição de linguagem. A linguagem é adquirida naturalmente na relação comunicativa que se estabelece na díade pais-bebê, por meio de sinais espontâneos e expressões faciais, corporais e orais (Yamada \& Valle, 2014). Quanto mais afetivamente estável for o vínculo entre os pais e o bebê, maior será o ganho da linguagem para a criança nos seus primeiros meses (Barcellos, 2011; Carvalho \& Santos, 2016). O descompasso na interação dos bebês surdos e seus pais pode afetar significativamente o processo de aquisição de linguagem da criança surda.

Diante disso, a discussão sobre a aquisição da linguagem na surdez e a comunicação na família é uma questão importante a ser considerada. A maior parte dos estudos prioriza a investigação da melhor estratégia para o desenvolvimento da linguagem na criança surda, com postulações a respeito da oralização e do bilinguismo (Barcellos, 2011; Carvalho \& Santos, 2016; Dias, Rocha, Pedroso \& Caporali, 2001; Dornelles, 2011). Independentemente da estratégia escolhida, esses estudos apontam que tanto a oralização quanto a introdução na língua de sinais acontecem tardiamente, quando muito já se passou no processo de subjetivação das crianças e de adaptação da família a esse novo membro.

$\mathrm{Na}$ interação com o filho surdo é esperado que os pais ouvintes privilegiem a fala e a escuta, que desejem que seus filhos se comuniquem da mesma forma que eles (Oliveira, Cúnico, Cunha, Kruel \& Tochetto, 2013). A expectativa da família ouvinte é, geralmente, que seu filho possa usar a Língua de Sinais entre os surdos e a Língua Portuguesa, na modalidade oral, com os ouvintes (Barcellos, 2011; Carvalho \& Santos, 2016; Silva, Pereira \& Zanolli, 2012; Silva, Zanolli \& Pereira, 2012; Kessler, 2008). Para os pais, a fala possibilitaria a integração dos filhos no mundo dos ouvintes, e os sinais, por outro lado, a melhor compreensão e o estabelecimento de relações sociais entre iguais.

Alguns pais abrem mão do projeto de ter um filho ouvinte e passam a investir intensamente para que a criança consiga falar (Carvalho, J., 2000). Dias, Rocha, Pedroso e Caporali (2001) apontam esse desejo como tentativa de proteção, uma vez que a preocupação desses pais é que os filhos não consigam se comunicar quando não estiverem com eles. Dessa forma, a criança é vista principalmente a 
partir da sua deficiência orgânica, representada pela incompletude. Os pais têm dificuldades de se adaptar às necessidades da criança, mas exigem que a criança se adapte ao mundo dos falantes (Carvalho, J., 2000). Especificamente em relação às mães, estas parecem imaginar que, se os filhos falarem, poderão afastá-los da deficiência, buscando assim o filho ideal da sociedade ouvinte (Barcellos, 2011).

Em uma família ouvinte, a comunicação principal é oral, e a criança surda, desde o início, é privada dessa interação. Segundo Stelling, Stelling, Santos Torres e Castro (2014), o não compartilhamento de uma língua comum é uma situação preocupante. É importante que os pais compreendam a necessidade de reciprocidade linguística, pois a ausência de uma língua em comum afeta o lado emocional do filho surdo, que se frustra por não conseguir ser entendido, além de fazer com que, frequentemente, a criança surda sinta-se excluída. Por outro lado, os pais também se sentem ansiosos e aflitos e, por vezes, inadequados e frustrados por não entenderem o que o filho está expressando, acarretando em afastamento e em desistência para se comunicar com a criança (Canho, Neme \& Yamada, 2006; Stelling, Stelling, Santos Torres \& Castro, 2014). Desta forma, as dificuldades encontradas na comunicação com o filho surdo formam uma barreira que também atrapalha cada vez mais a interação, tornando a comunicação superficial e restrita a gestos e/ou mímicas. A ausência de vivência, de experiências e de trocas comunicativas se torna um obstáculo no estreitamento dos laços afetivos entre os pais e o filho surdo, além de ter repercussões no desenvolvimento da criança (Yamashiro \& Lacerda, 2016; Negrelli \& Marcon, 2006).

$\mathrm{Na}$ interação com o filho surdo, os pais tendem, portanto, a privilegiar a modalidade de língua correspondente às suas percepções sobre a perda auditiva. Os pais que compreendem a surdez como patologia buscam se comunicar através do português falado, enquanto os que a veem como uma diferença fazem uso da língua de sinais, da fala e de diversas estratégias comunicativas (Silva, Pereira \& Zanolli, 2012; Paula \& Pereira, 2014). Cabe ressaltar que os pais são diretamente influenciados pelas informações recebidas, principalmente no período após a confirmação do diagnóstico (Silva, Pereira \& Zanolli, 2012). Após o diagnóstico clínico, geralmente a primeira orientação que os pais ouvintes recebem é a do enfoque clínico pelo médico otorrinolaringologista ou pelo fonoaudiólogo, que recomendam oralização e estimulação auditiva (Ruggieri-Marone, Lichtig \& Marone, 2002; Paula \& Pereira, 2014). Porém, as informações e orientações 
recebidas pelos pais são diversas vezes inadequadas, pouco claras e confusas, dificultando a compreensão sobre a surdez, o potencial linguístico e as habilidades auditivas da criança (Paula \& Pereira, 2014).

O confronto com o bebê real, surdo, desperta na família intenso processo de adaptação para atender às necessidades próprias daquela criança. De acordo com Amiralian (1986), alguns projetos e expectativas deverão ser reformulados devido à nova realidade. A flexibilidade de cada família em lidar com a nova situação depende da história de cada membro, do sistema de crenças, da capacidade de enfrentar situações de mudança, da existência ou não de um lugar para a criança dentro do sistema familiar, do nível de expectativas, da capacidade de comunicação do grupo familiar, da existência ou não de uma rede de apoio e da capacidade da família de se relacionar com os outros e de buscar ajuda.

Behares (2000) sublinha que o conhecimento sobre a surdez demanda um longo processo. É necessário garantir um espaço para a vivência do luto pelo filho idealizado e para a abertura de um lugar para o filho real, para que este possa ser olhado em sua subjetividade - que tem a surdez como marca, mas que não é definido exclusivamente por ela. Os pais precisam estar atentos à interação com a criança, permitindo que se desenvolva dentro de suas possibilidades e potencialidades. O papel do cuidador e a dinâmica familiar são decisivos no que se refere ao modo como a criança enfrentará sua deficiência e sua relação com o mundo (Oliveira, Simionato, Negrelli \& Marcon, 2004). 


\section{4 \\ Desvelando a parentalidade na surdez: estudo de campo}

Foi realizada uma investigação de natureza qualitativa com o objetivo de investigar como os pais e mães ouvintes vivenciam a parentalidade com um filho surdo. Como objetivos específicos, pretendemos investigar o impacto do diagnóstico da surdez para os pais ouvintes e identificar os facilitadores e os dificultadores do exercício da parentalidade no contexto de pais ouvintes e filho surdo.

\section{1}

\section{Participantes}

Entrevistamos oito pais ouvintes, sujeitos independentes (quatro homens e quatro mulheres), com idades entre 23 e 42 anos, com filhos surdos, com idades entre 3 e 6 anos. Todos os entrevistados residem na cidade do Rio de Janeiro e são pertencentes às camadas médias da população. Os filhos surdos de cinco participantes estudam na mesma instituição de ensino especializada em surdez.

A seguir, apresentamos um quadro de identificação dos participantes (Quadro 1). A identidade deles foi preservada e, por esta razão, todos os nomes utilizados nos relatos são fictícios.

\section{2 Instrumento da pesquisa}

Este estudo utilizou como instrumento de coleta de dados uma entrevista semiestruturada, baseada em um roteiro oculto (Anexo 1), que continha os seguintes eixos temáticos, formulados a partir da revisão da literatura sobre o tema pesquisado: vivência da gravidez, expectativas parentais, confronto com a surdez, vivência da parentalidade, relação com a família, rede de apoio e projeto de vida. Primeiramente, realizamos uma entrevista piloto com o objetivo de testar e aprimorar nosso roteiro inicial, a fim de construir uma entrevista mais adequada para atingir os objetivos da pesquisa. 
Quadro 1. Dados de identificação dos participantes

\begin{tabular}{|c|c|c|c|c|c|c|c|}
\hline Entrevistado(a) e idade & Escolaridade & Ocupação & Filho(a) surdo e idade & $\begin{array}{l}\text { Etiologia da surdez do } \\
\text { filho(a) }\end{array}$ & $\begin{array}{l}\text { Idade do diagnóstico de } \\
\text { surdez do filho(a) }\end{array}$ & Implante Coclear & $\begin{array}{c}\text { Instituição de } \\
\text { ensino do } \\
\text { filho(a) }\end{array}$ \\
\hline \multirow{2}{*}{ Rosa, 42 anos } & \multirow{2}{*}{$\begin{array}{l}\text { Ensino Médio } \\
\text { incompleto }\end{array}$} & \multirow{2}{*}{ Costureira } & Gabriel & \multirow{2}{*}{ Idiopática } & \multirow{2}{*}{2 anos } & \multirow{2}{*}{ Na fila de espera } & \multirow{2}{*}{$\begin{array}{c}\text { Escola } \\
\text { especializada } \\
\text { em surdez }\end{array}$} \\
\hline & & & 5 anos & & & & \\
\hline \multirow{2}{*}{ Cláudia, 34 anos } & \multirow{2}{*}{ Ensino Médio } & \multirow{2}{*}{ Dona de casa } & Bárbara & \multirow{2}{*}{ Má formação na cóclea } & \multirow{2}{*}{1 ano e 3 meses } & \multirow{2}{*}{ Não pode } & \multirow{2}{*}{$\begin{array}{c}\text { Escola } \\
\text { especializada } \\
\text { em surdez }\end{array}$} \\
\hline & & & 6 anos & & & & \\
\hline \multirow{2}{*}{ Mara, 29 anos } & \multirow{2}{*}{$\begin{array}{l}\text { Ensino Superior } \\
\quad \text { (cursando) }\end{array}$} & \multirow{2}{*}{$\begin{array}{l}\text { "Mãe em tempo } \\
\text { integral" }\end{array}$} & Alan & \multirow{2}{*}{ Idiopática } & \multirow{2}{*}{1 ano } & \multirow{2}{*}{$\begin{array}{l}\text { Há } 04 \text { anos no ouvido } \\
\text { direito e há } 08 \text { meses } \\
\text { no ouvido esquerdo }\end{array}$} & \multirow{2}{*}{ Escola regular } \\
\hline & & & 6 anos & & & & \\
\hline \multirow{2}{*}{ Ana, 37 anos } & \multirow{2}{*}{ Ensino Fundamental } & \multirow{2}{*}{ Dona de casa } & Bruna & \multirow{2}{*}{ Otite recorrente } & \multirow{2}{*}{6 meses } & \multirow{2}{*}{ Na fila de espera } & \multirow{2}{*}{$\begin{array}{c}\text { Escola } \\
\text { especializada } \\
\text { em surdez }\end{array}$} \\
\hline & & & 4 anos & & & & \\
\hline \multirow{2}{*}{ João, 29 anos } & \multirow{2}{*}{$\begin{array}{l}\text { Ensino Médio } \\
\text { incompleto }\end{array}$} & \multirow{2}{*}{ Supervis or Operacional } & Lucas & \multirow{2}{*}{ Idiopática } & \multirow{2}{*}{1 ano } & \multirow{2}{*}{$\begin{array}{c}\text { Há } 02 \text { meses no ouvido } \\
\text { direito }\end{array}$} & \multirow{2}{*}{$\begin{array}{l}\text { Não está na } \\
\text { escola }\end{array}$} \\
\hline & & & 3 anos & & & & \\
\hline \multirow{2}{*}{ Rafael, 23 anos } & \multirow{2}{*}{ Ensino Médio } & 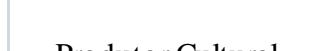 & Diego & 1. & 20 & $\tilde{N} \tilde{\sigma}$ & Não está na \\
\hline & & 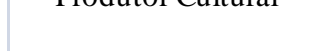 & 3 anos & & & & escola \\
\hline Iocias 44 ano & Encino MǴdi & Somuranco & Antônio & Idionótico to & 0 mecoc $>$ & Há 01 ano no ouvido & Escola \\
\hline Josias, 44 anos & Ensino iviedio & Seguranç̧a & 5 anos & Idiopatica & 9 meses & direito & em surdez \\
\hline M & Encing Módir & A vilio A dminic totive & Pedro & Jdionótion to & 2 anos & Na fila de ecnera & Escola \\
\hline & & & 5 anos & Iuiopatica & 2 ands & Na llla uespera & em surdez \\
\hline
\end{tabular}

Fonte: elaborado pela autora 


\section{3}

\section{Procedimentos}

Os participantes foram selecionados pela pesquisadora a partir de contatos informais em diferentes redes de sociabilidade. As entrevistas foram individuais e presenciais, marcadas em horários e locais de acordo com a conveniência dos participantes - cinco foram gravadas na instituição de ensino em que os filhos estudam, duas na instituição em que os filhos realizam assistência terapêutica e uma na instituição religiosa que o participante frequenta.

O projeto foi submetido ao Comitê de Ética em Pesquisa da universidade e aprovado conforme o Parecer $\mathrm{N}^{\mathrm{o}}$ 06/2018. Todos os participantes foram informados, antes da entrevista, dos objetivos do estudo e concordaram em assinar o Termo de Consentimento Livre e Esclarecido (Anexo 2), garantindo-se o direito de não participação e/ou desistência em qualquer etapa da pesquisa. Nesse documento também estão assegurados a segurança e o sigilo das informações coletadas. As entrevistas foram gravadas em áudio e, posteriormente, transcritas integralmente, visando à preservação de todo o discurso dos entrevistados.

\section{4 \\ Análise e discussão dos dados}

A análise dos resultados foi realizada através do método de análise de conteúdo (Bardin, 2011), na sua vertente categorial, para que pudéssemos interpretar os dados de todos os entrevistados, comparando os conceitos e temas abordados pelos participantes a partir da literatura revisada, visando a atingir os objetivos formulados e levantar novas questões de pesquisa.

A partir da análise dos dados, emergiram seis categorias de análise: 1) Descoberta da surdez: da suspeita à confirmação do diagnóstico; 2) Confirmação do diagnóstico: luto na parentalidade com um filho surdo; 3) $O$ ideal do filho falante; 4) (Des)conhecimento da surdez e sua influência nos cuidados parentais; 5) Rede de apoio na surdez; 6) Tornando-se pais resilientes. 


\section{Descoberta da surdez: da suspeita à confirmação do diagnóstico}

Durante a gravidez, a maioria dos pais cria expectativas acerca da criança, imaginam o sexo, o nome, as características físicas, dentre outras, e a possibilidade de ter um filho com alguma deficiência geralmente é descartada. Quando começam a suspeitar que o filho não nasceu da forma que sonhavam, principalmente quando não há razões perinatais ou pré-natais que indiquem a perda auditiva, os pais enfrentam uma situação inesperada e apresentam diversas reações até a confirmação da surdez do filho. Esta categoria de análise aborda como é vivenciado pelos pais ouvintes o processo da suspeita da surdez até a confirmação de seu diagnóstico. Os pais e mães entrevistados trazem em suas narrativas a dificuldade de aceitação da perda auditiva, manifestada no relato da vivência de um momento inicial de descrença e de negação da percepção de comportamentos diferentes da criança. De forma geral, os pais tendem a buscar explicações e justificativas para descaracterizar a suspeita da surdez, acarretando na postergação da confirmação do diagnóstico.

Alguns pais relataram que esperavam que seus filhos nascessem saudáveis e que fossem crianças normais, uma vez que não houve intercorrências durante a gravidez e o parto.

\footnotetext{
“(...) foi uma gravidez tranquila... fiz todos os exames, pré-natal completo, não tive nada na gravidez, não tive nenhuma doença. Foi uma gravidez tranquila, muito tranquila mesmo. O nascimento dela também foi tranquilo, ela nasceu no tempo certo, com 39 semanas. Aí, ela ao nascer, uma criança normal. Eu fiquei feliz porque era uma menina, já tinha um menino, era tudo que eu pedia! E aí fiquei com um casal e foi tudo tranquilo. Ela foi uma criança calma, que não tinha problemas de saúde. Um bebê calmo que não tinha problemas de saúde nenhum. Não tinha como a gente imaginar.” (Cláudia, 34 anos)

"A gravidez do Gabriel foi tranquila. Eu trabalhei costurando até nove meses e cinco dias. E foi tranquilo! Eu fiz todos os exames não dava nada errado. Fiz tudo direitinho, fiz direitinho. Eu não faltava consulta nenhuma. Não dá pra esperar que isso vai acontecer... não tem explicação, só tem a de Deus, eu só falo isso." (Rosa, 42 anos)

"E ela [esposa] fez tudo, teve todo o acompanhamento. Tudo normal, normal. E, poxa, como estava tudo tranquilo, fiquei numa boa, né? Não me preocupei, nem pensava nisso... Então, ai nos deparamos com essa surdez dele." (Josias, 44 anos)
}

A surdez, por não ser aparente fisicamente, muitas vezes não é identificada imediatamente. Como o bebê surdo tem reações semelhantes ao bebê cuja audição não está prejudicada, a família só começa a desconfiar de algum problema auditivo da criança quando esta não se assusta e/ou não reage a sons muito fortes, ou quando 
não desenvolve a fala (Silva, Pereira \& Zanolli, 2012; Silva, Zanolli \& Pereira 2008).

"Ela não olhava pra televisão pra ver um desenho ou pra... um som. Eu falei 'ela não tá ouvindo o som'. A porta batia e ela nem piscava! Pensei 'a minha filha tá sem audição'." (Ana, 37 anos)

"Fui eu mesmo que percebi mais a fundo, quando eu tava brincando de pique-esconde com ele, né? Assim, ele já engatinhava já, fazia tudo... e eu senti que ele tava concentrado em me procurar e aí eu me escondi. Aí quando eu cheguei atrás dele e chamei: 'Pedro! Pedro!' e ele não virou, não reagiu. Aí acendeu um alerta que aí eu falei com minha esposa, né, 'Olha, alguma coisa tá acontecendo aqui'.' (Marcos, 35 anos)

“(...) ai quando tinha fogos, essas coisas assim, ele ficava na boa, não se assustava e tudo mais... e eu falei 'cara, eu acho que ele não escuta, tem alguma coisa no ouvido dele, sei lá, porque... ele não... cai um prato, bate uma porta, o menino fica estagnado, não faz nada'." (Mara, 29 anos)

No momento em que a família desconfia que a criança não escuta e não manifesta reações, passa a testar a audição dos filhos com a intenção de verificar se suas suspeitas são verdadeiras (Silva, Zanolli \& Pereira, 2008).

“(...) aí comecei a perceber... e testava, chamava, chamava, ia por trás dela e chamava e nada.” (Ana, 37 anos)

“(...) eu peguei as duas tampas de panela, mandei ele ficar de costas assim pra mim e 'bum' [vocalização das tampas batendo] e aí, ele não virou. Aí eu ficava chamando bem pertinho dele, chamava alto e ele não virava. Só quando eu tocava nele, ele virava." (Rosa, 42 anos)

No entanto, a desconfiança pode ser despistada por outros sinais e comportamentos apresentados pela criança, conforme podemos perceber em algumas falas.

"Olha, porque assim, a gente começou a fazer teste em casa. Ele devia ter uns 2 anos e pouco quando a gente começou a testar. Ficava chamando de costas e chamando o nome dele e ele não olhava e, em outras, olhava. E isso confunde a gente, né? '” (Marcos, 35 anos)

"Porque ele deixa isso tudo muito na dúvida. Porque tem hora que você fala assim 'João' e ele não vai olhar. Aí, você fala de novo 'João' e ele te olha. E ai tu fica assim sem entender. Ou eu não sei se ele programou uma coisa na cabeça...” (Rafael, 23 anos)

"Porque ele balbuciava, emitia som... ficava "ma-ma-ma" só, normal. Pra mim aquilo era normal, um bebezinho fazendo "ma-ma-ma”. A pessoa surda, ela não emite som nenhum, e o Alan emitia. Assim, eu acho que ele escutava e depois foi perdendo, só pode." (Mara, 29 anos)

"Eu não acreditava! Ele balbuciava... Tipo assim, ele não falava, mas tem criança que você olha assim na internet e fala que é normal não falar até dois anos.” (Josias, 44 anos)

Trindade (2017) afirma que a responsividade da criança surda difere pouco da responsividade da criança ouvinte, e ressalta que o balbucio do filho pode fazer 
com que os pais demorem a suspeitar da surdez. A resposta da criança às vibrações e aos sons mais graves pode mascarar também a incapacidade em compreender os sons da linguagem falada. Somado a isso, estudos demonstram (Luterman, 1979; Silva, Zanolli \& Pereira, 2008; Silva, Pereira \& Zanolli, 2012; Vieira, Bevilacqua, Ferreira \& Dupas, 2012) que, no momento em que os pais começam a desconfiar, estes se mostram resistentes a pensar que algo pode estar diferente com o filho. Reagem de forma defensiva, utilizando os mecanismos de negação - quando os pais ignoram a percepção dos sinais da perda auditiva da criança - e de racionalização, interpretando qualquer movimento como resposta ou atribuindo explicações, conforme apontado nas falas dos entrevistados. O estereótipo cultural da criança ideal gera nos pais a expectativa de que o filho seja bem-sucedido em tudo, e isso pode contribuir para a reação de "simplesmente não pode ser" quando percebem que a criança tem um problema aparente (Mannoni, 1999).

A maioria dos entrevistados afirma que os filhos não fizeram o teste da orelhinha. Somente em três casos o exame foi realizado e a perda auditiva não foi constatada. Em um desses casos, a criança ficou surda após crises de otite recorrentes aos dois meses. João, cujo filho realizou o exame, aponta que o resultado negativo deste para a surdez foi um dos fatores que contribuiu para o adiamento da suspeita de surdez.

“(...) um dia ele tava na praia e minha irmã falou 'João, eu acho que o Carlos não escuta direito'. Sendo que quando eu brigo com ele, quando eu mudo o tom, ele olha. Então, eu achava que ele escutava. Poxa... ele olhava... E ele fez o teste da orelhinha e deu normal. Aí eu fiquei muito p... da vida. Aí falei pra ela 'aí tu leva ele, então'. Ah pra mim foi muito dificil. Porque eu não acreditava." (João, 29 anos)

Uma das conquistas mais esperadas pelos pais é o início da fala. No entanto, é nesse período de aquisição da linguagem que a criança surda começa a apresentar comportamentos que podem ser mais sugestivos de alguma dificuldade, deixando os pais apreensivos.

“(...) o Marcelo já tava começando a falar e os meus filhos são gêmeos, eles sempre começaram a fazer tudo juntos. E o Diego não tava fazendo isso e passou um tempo e ele não fez. E aí, eu pensei 'eu preciso ir ver isso porque o meu filho não fala'." (Rafael, 23 anos)

"E na época, a minha sobrinha tinha nascido em novembro, o Alan nasceu em fevereiro, então, assim, tinha um comparativo, pô, minha sobrinha já tá falando 'mamãe', 'papai' e o Alan só fica nesse 'ma-ma-ma...' Aaah, não! Isso é normal!’ (Mara, 29 anos)

“(...) uma vez ele falou 'papá’, mas saiu, assim, né, 'papá’. E então a gente ficou naquela... 
mas depois ele não falou mais nada também, né? Aí depois a gente viu que não desenvolveu..." (Josias, 44 anos)

Outro elemento que influencia na forma de os pais lidarem com a suspeita da surdez, dificultando a busca pelo diagnóstico precoce, é a não suspeita e a qualificação precária dos profissionais de saúde para avaliar sinais precoces de perda auditiva.

'Eu questionei a pediatra 'eu acho que tem alguma coisa diferente na minha filha'. Aí a pediatra falou assim 'não, mãe, você tá louca, não tem nada, a sua filha é normal, linda!', e aí eu fui levando aquilo... mas sempre notando, assim, alguma coisa. Eu sempre achei assim, que tem alguma coisa diferente nessa menina, dela com o irmão. A questão dela dormir muito e, assim, eu moro perto de uma escola de samba e no final de semana é muito barulhenta a minha rua e, às vezes, até dia de semana. Fogos e ela não chorava. Estourando bola, ela não chorava. Ela não se incomodava com barulhos. E eu comecei a perceber e questionando a pediatra, mas a pediatra falou que era totalmente normal. A pediatra bateu palminha atrás do ouvido dela, ela olhou, ai a pediatra falou assim 'Não, tá vendo? Ela ouve!'. Ai eu falei assim 'é, mas eu... o meu olhar de mãe acha que tem alguma coisa'." (Cláudia, 34 anos)

"Perguntava ao pediatra e ele dizia 'Não, isso é normal, criança é assim... ela vive no mundinho dela, entendeu?'. Essa que era a alegação dele. E ele dizia 'não tem problema' e eu 'cara, ele não tá escutando', e o pediatra 'não, isso é normal'. Ai tipo, todo mês, né, tem que fazer o acompanhamento, voltava lá, né? 'Cara, tá muito estranho, eu queria que você passasse pra mim uma audiometria, alguma coisa porque eu tô achando estranho... porque se eu pegar aqui um prato agora e tacar aqui ele não escuta', 'não, mas isso é normal... '. E ele ficou alimentando isso 'até os 3 anos é normal a criança não manifestar... falar e tudo mais', 'Aaah, não, isso é normal!' 'Ah, é menino, demora um pouco mais pra falar... ', vem com essas coisas lá de antigamente.” (Mara, 29 anos)

“(...) então, nós fomos falar com o pediatra dele e ele falou que 'é assim mesmo, ele tá reagindo'. E ele tava bem adiantado com as outras coisas, né? Ele falou 'olha, quando uma criança é bem adiantada em uma coisa, atrasa outra, você entendeu?'. Ele já tava quase andando já, tava bem esperto. Ele fez até uns testezinhos com ele ali na hora e tal, no ouvido dele, alguma coisa assim, mas não... não levou pra frente não o nosso questionamento. Aí, bem depois de mais uns 2 meses mais ou menos, é que voltamos lá e falamos da mesma coisa" (Marcos, 32 anos)

Apenas uma participante relatou que, como a criança apresentou um quadro de otite recorrente e perdeu a audição devido a essa infecção, a suspeita da mãe foi legitimada pelo profissional de saúde.

"Por ela ter tido tanta otite, começou aos 02 meses, e meu esse outro filho de 8 anos também teve, mas a dele nunca interferiu em nada, audição normal, tudo normal. Mas ela eu vi que não voltou a audição... ela foi ficando séria, não olhava mais quando eu chamava... pensei 'pode ser que seja por causa da inflamação, vou esperar secar'. Esperei secar e nada, ai fui no médico e ele passou o exame." (Ana, 37 anos)

Os pais relatam possíveis descuidos do pediatra no acompanhamento da criança, que desconsideram as falhas no desenvolvimento e não investigam as suspeitas dos pais. Colazza e Anastasio (2009) afirmam que geralmente os pediatras investigam pouco a audição nos exames de rotina, além de possuírem 
poucas informações sobre a surdez, suas causas, tipos e formas de avaliação. Ademais, durante a avaliação de rotina realizada por profissionais de saúde, a perda auditiva também pode ser mascarada devido aos sinais imprecisos, ao resíduo auditivo e à habilidade visual da criança surda (Lima, Boechat \& Tega, 2003).

Por outro lado, refletindo sobre a postura dos profissionais de saúde, Cortelo e Françoso (2014), com base nos conceitos de transferência e contratransferência, questiona até que ponto essa atitude não seria uma forma de identificação do médico com a dor e outros sentimentos dos pais. Para o autor, os pediatras respondem aos pais na medida do desejo deles, ou seja, confirmando que não há nada de errado com o desenvolvimento do filho.

Conforme descrito anteriormente, observamos a demora entre o tempo de suspeita e a confirmação do diagnóstico. A maioria dos entrevistados percebeu a surdez dos filhos a partir dos 6 meses de idade, mas a suspeita foi despistada, adiando assim a investigação. Os entrevistados não tiveram acesso ao diagnóstico precoce, em torno dos três meses. Um pouco mais da metade dos entrevistados teve a confirmação da surdez de seus filhos em torno de 1 ano e meio de idade. Dois tiveram mais tardiamente, um aos 2 anos e outro aos 3 anos. E somente um caso foi aos 6 meses, devido ao quadro clínico da criança. Entretanto, para a realidade brasileira, esses diagnósticos ocorreram precocemente. De acordo com a literatura nacional, o diagnóstico das perdas auditivas ocorre entre os três ou quatro anos de idade (Silva, Pereira \& Zanolli, 2012; Vieira, Bevilacqua, Ferreira \& Dupas, 2012). Cabe ressaltar que o tempo de demora em perceber e admitir a perda auditiva do filho, somado a uma busca tardia de atendimento, pode gerar prejuízos significativos no desenvolvimento da criança (Negrelli \& Marcon, 2006).

\section{Confirmação do diagnóstico: luto na parentalidade com um filho surdo}

A vivência do luto pelo filho idealizado consiste em um delicado processo de adaptação ao bebê real, que ocorre no nascimento de toda criança. No entanto, quando há uma diferença marcante entre o bebê sonhado e o real, como no caso de filhos surdos, os pais ouvintes têm maior dificuldade em elaborar esse luto, tornando difícil o investimento no filho que nasceu. Esta categoria aborda a vivência dos pais após a confirmação do diagnóstico de surdez do filho. No discurso 
dos entrevistados, as emoções que surgem nesse primeiro momento são descritas com grande pesar, permeadas por sentimentos de tristeza e frustração. Há uma incompreensão inicial acerca da situação e, em seguida, a vivência do luto pela perda do filho "normal" que tanto desejaram.

As reações e os sentimentos dos pais frente ao diagnóstico podem ser diversas. Os entrevistados relatam, em sua maioria, decepção, susto, descrença e angústia ao confirmarem que seus filhos eram surdos.

\footnotetext{
"Eu fiquei triste, eu fiquei muito triste, assim, porque eu não sabia nada sobre surdez, né? Aí, quando eu descobri o meu mundo caiu. Assim, que eи não sabia o que que era surdez, não sabia nada. Tive aquele meu período de luto pela surdez dela." (Cláudia, 34 anos)

“Então, ai nos deparamos com essa surdez dele, tomamos um susto, né? É um baque, né, que a gente toma realmente 'e agora, como é que vai ser', 'caramba, cuidar de uma criança especial'... Cara, é... realmente bateu uma frustração, né?"' (Josias 44 anos)

"Mas no começo foi difícil, foi difícil... a sensação quando eu descobri que ele era surdo foi de o mundo acabar... eu não sabia o que fazer..." (João, 29 anos)
}

A confirmação da surdez, atestando o nascimento de uma criança totalmente diferente da esperada pelos pais, parece se configurar como uma situação de crise. Os pais reagem com frustração à confirmação do diagnóstico (Asano, Neme \& Yamada, 2010; Silva, Zanolli \& Pereira, 2008). Amaral (1995) afirma que os pais ouvintes apresentam um estado de pesar e luto pelo filho desejado e idealizado. O processo de luto se constitui justamente a partir da perda dos planos, sonhos e projetos que tinham para a criança que não nasceu "normal", "saudável". As expectativas e os sonhos que os pais tinham para o filho são rompidos com a confirmação do diagnóstico (Asano, Neme \& Yamada, 2010; Sá \& Rabinovich, 2006; Silva, Zanolli \& Pereira, 2008; Vieira, Bevilacqua, Ferreira \& Dupas, 2012).

Diante disso, nesse primeiro momento após a confirmação da surdez, muitos entrevistados descrevem a vivência de uma situação de "choque", caracterizada por uma reação inicial de descrença em relação ao diagnóstico, paralisação e certa evitação do filho diante dessa situação inesperada.

“Então, foi difícil porque a gente ficava naquela luta... como vai fazer? Porque, assim, aí a gente já sabia que o que o Diego tinha. Logo no início a gente não acredita e tal... e a gente ficou uns 6 meses parado (...) nós não tínhamos uma base, um apoio de alguém que conhecesse, que sabia. A gente ficou muito agoniado, sem saber o que fazer a partir de agora. E aí eu me afastei dele. Quando eu descobri que ele era surdo eu fiquei frio com ele." (Rafael, 23 anos)

"E tivemos um tempinho ainda no escuro, sem saber direito.... eu não sabia como lidar com ele e foi difícil no começo." (Marcos, 32 anos) 
“(...) eu fiquei em choque... foi difícil e eu sumi da instituição... É, porque eu fiquei pensando, não sei o que que eu vou fazer com essa menina agora.... eu peguei o diagnóstico e um dia depois eu não vim mais aqui, não... isso durou o que... uns 6 meses... eu relutei um pouco..." (Cláudia, 34 anos)

Os relatos acima evidenciam as dificuldades dos pais em admitir a perda auditiva do filho e lidar com o diagnóstico. A reação inicial de choque é descrita por diversos autores (Bowlby, 1969/2002; Luterman, 1979; Mannoni, 1999; Worden, 1998) como um processo natural do luto. Neste momento, é esperado um entorpecimento, principalmente devido ao desconhecimento da surdez (Luterman, 1979; Luterman, Kurtzer-White \& Seewald, 1999).

Cabe destacar ainda a dificuldade dos pais em interagir com o filho quando descobrem que ele é surdo, fato observado no relato dos pais, que mencionaram se sentir pouco à vontade e sem saber como brincar e interagir com um filho que "não escuta" e que "não entende". Após perceberem a severidade da surdez e reconhecerem as dificuldades da situação e da vinculação com o filho, os pais podem vivenciar grande sofrimento e frustração por sentirem-se inadequados para a tarefa de criar um filho surdo, ocasionando uma reação de pânico e um movimento de distanciamento em relação à criança (Silva, Zanolli \& Pereira, 2008; Yamada, Moretti, Prado \& Bevilacqua, 2014; Yamada \& Valle, 2014).

Sobre o distanciamento, Rossi (2003) e Yamada, Moretti, Prado \& Bevilacqua (2014) consideram ainda que, após o diagnóstico de surdez, a interação dos pais com a criança sofre grandes modificações. No início, a troca com a criança é marcada por afetividade e responsividade e, após o diagnóstico, a sensação de frustração e tristeza e, até mesmo, pena da criança, podem se desdobrar em dificuldades na experiência de intimidade com o filho, gerando distanciamento. Assim, os pais ficam pouco disponíveis para exercer a parentalidade, o que pode impactar no desenvolvimento emocional da criança.

Nesse processo, é comum identificar uma fase de reação defensiva, ou negação, dos pais (Silva, Zanolli \& Pereira, 2008), percebida, na maior parte dos relatos, através da desconfiança com relação ao diagnóstico.

"Ela não escuta. Aí eu olho, assim, tipo assim, será mesmo? Porque ela interage tão bem! Não parece, né? Não parece mesmo.” (Ana, 37 anos)

"Ele deixa tudo muito duvidoso. Porque eu boto ele para fazer as coisas e ele faz (...) a gente em casa, teve uma vez que eu virei e falei, assim, e ele sem aparelho [auditivo], "vai lá chamar mamãe e pede para ela vir aqui', ele sem aparelho foi lá em cima e chamou.' (Rafael, 23 anos) 
A negação é um mecanismo de defesa muito utilizado pelos pais diante do diagnóstico de surdez dos filhos. Cortelo e Françozo (2014) pontuam que essa recusa em aceitar o diagnóstico através da desconfiança, da busca por explicações e por outros exames, médicos e opiniões, proporciona aos pais tempo para se distanciar das vivências dolorosas desse processo. A busca por outros profissionais é um comportamento descrito com muita frequência em outros estudos (Cortelo \& Françozo, 2014; Luterman, 1979; Luterman, Kurtzer-White \& Seewald, 1999), mas não houve referência a isto por parte dos entrevistados.

Outras formas de atuação desse mecanismo de defesa foram percebidas nos relatos dos entrevistados através da afirmação reiterada de que o filho é uma criança normal e que ninguém percebe que é surdo e, ainda, pela minimização da surdez.

\begin{abstract}
“(...) e o pessoal conversando com ele normal, aí ele faz que não entende [representando em sinais]. E eu falo 'não se preocupa porque ele é surdo'. Ai depois de muito tempo que as pessoas conversando com ele vai perceber que ele é surdo, mas só porque ele não responde nada, só em Libras. Eles olham pra ele e parece uma criança normal. Você só percebia a surdez dele porque ele não fala. Não parece mesmo." (Cláudia, 34 anos)
\end{abstract}

"E ele tá uma criança... se você vê ele, você diz que ele não parece ser surdo. Porque ele só tem mesmo a surdez." (Rosa, 42 anos)

"Ele é amigo de todo mundo, se dá bem como todo mundo... Ele é uma criança normal, esperta, nem parece surdo... só não fala ainda." (Marcos, 32 anos)

Diante da dificuldade em lidar com a experiência de ter uma criança tão diferente do que esperavam, é legítima a utilização desse mecanismo de defesa para que os pais possam tornar a nova realidade mais tolerável. Esses dados corroboram os achados da pesquisa de Yamada, Moretti, Prado \& Bevilacqua (2014). É importante destacar que a negação é um mecanismo adaptativo, permite aos pais um tempo necessário de evitar a realidade dolorosa e, assim, continuar o enfrentamento, desde que não permaneça de forma rígida, impedindo o contato e o lidar com a realidade.

Observamos na fala de um entrevistado a necessidade de encontrar elementos que justifiquem a perda auditiva do filho.

\footnotetext{
“Assim, para mim ele não nasceu com surdez, não nasceu com nada. Pra mim foi depois que ele, perto de completar 1 mês, e que começaram a dar esse remédio para ele, que ele teve isso." (Rafael, 23 anos)

"Você não acredita que vai acontecer com você, porque vocêfala assim 'eu sou saudável', 'aonde eu errei?'. Eu já me perguntei 'Deus, aonde eu errei pro meu filho ser assim?' eu já me fiz essa pergunta." (Rafael, 23 anos)
} 
"No candomblé eles dizem que isso é um castigo. É um castigo, entendeu? Conta que não acertou em você, mas acertou em que você vai amar, como os filhos, por exemplo. E foi um castigo por tudo que ela fez [referindo-se ao uso de drogas da mãe durante a gravidez e após o nascimento], porque ela é a mãe, entende?" (Rafael, 23 anos)

Desejando entender as causas da surdez do filho, Rafael questiona o uso de das medicações durante a internação do filho, busca explicações baseadas em sua crença religiosa e, ainda, relata se sentir pessoalmente responsável pelo diagnóstico. Comumente, diante do diagnóstico, os pais buscam culpados pela surdez do filho (intercorrências gestacionais, procedimentos médicos etc.), incluindo as autoacusações. Muitas vezes, os pais apresentam fantasias de culpabilização, nas quais a falta de amor, de cuidados e do desejo pelo filho causaram a surdez, fazendo-os sentir que estão sendo punidos e castigados por alguma coisa grave que fizeram (Silva, Zanolli \& Pereira, 2008; Kelman, Silva, Amorim, Monteiro \& Azevedo, 2011; Yamada, Moretti, Prado \& Bevilacqua, 2014).

Por outro lado, é comum que os pais procurem sentidos para a experiência de ter um filho surdo.

\footnotetext{
"Então, pra mim foi um susto, assim, por ser a minha filha. Gente, minha filha, por que que aconteceu isso? Por que aconteceu isso? E essas coisas a gente não pode nem questionar... se Deus botou, você vai cuidar e cabou. Se ele botou é porque você é capaz de cuidar (...) Porque, às vezes, Deus prepara, né? Ele dá filhos especiais pra mães especiais." (Ana, 37 anos)

"Ele, graças à Deus, eu acho que dos males veio o menos pior: não escutar. Porque tem muita criança aí que, Deus me livre, não anda, tem problema aí de síndrome de Down, isso tudo... poderia ter acontecido isso com ele... Então, pra mim, dos males ele veio com o menos pior, que é o dele não escutar. Ele faz tudo, joga bola normal." (João, 29 anos)
}

Algumas mães relatam sentirem-se escolhidas por Deus para ter um filho surdo. Esses dados corroboram os achados de Oliveira, Silva, Frota, Pinto, Frota e Sá (2008), que assinalam que a espiritualidade pode trazer significados à deficiência e consolo diante do novo desafio. Segundo os autores, o fato de se sentirem escolhidas por Deus para cumprir a missão de ter um filho deficiente permite a compreensão desta como uma dádiva e, assim, sentem-se capacitadas para tal missão. Sobre esse movimento de busca por sentidos, Frankl (1989) postula que o sentido extraído dessas vivências é a força motivadora para o enfrentamento, o fio condutor para uma existência mais saudável. Neimeyer (2001) também ressalta a importância da construção de significados no processo de luto. Desta forma, poder desenvolver uma narrativa coerente ao acontecido permite ao enlutado integrar a perda e o luto, o que pode reduzir o pesar, além de reconstruir sua identidade e 
restaurar o sentido da vida. Assim, o significado atribuído pelos pais a esse processo é fundamental para a aceitação da criança real e para o processo de ajustamento da família (Petean \& Murata, 2000).

Ademais, há um senso maior de competência e vontade de enfrentamento quando a busca de sentido faz parte do processo. Nesses casos, os pais podem elaborar a culpa, reexaminar seus valores e reestruturar suas vidas, adaptando-se à surdez do filho (Luterman, 1979; Luterman, Kurtzer-White \& Seewald, 1999). Os entrevistados descrevem um interesse em conhecer mais sobre a surdez e manifestam o desejo de seguir em frente, lutando por melhor qualidade de vida para os filhos.

\footnotetext{
"Mas eu levei um susto sim, mas... tentei na mesma da hora não baixar a guarda... tentei seguir... falei 'não, vou procurar recursos, já que ela é surda então vou entrar no mundo dela e vou começar a procurar recurso pra minha filha'. Porque não é eu que vou depender dela, é ela que vai depender de mim. E se ela vai depender, então eu tenho que ver o melhor pra ela." (Ana, 37 anos)

“Ai eu falei assim 'Poxa, eu tenho que aceitar!'. E agora eu vou ter que moldar a minha vida à dele. E eu fui preparando o meu coração." (Rafael, 23 anos)

"Porque quando eu engravidei do meu filho, eu desejei meu filho, ele podia vir do jeito que ele fosse, é meu. Ele podia vir todo tortinho... mas eu vou dar um jeito dele viver melhor e bem, ao meu lado, entendeu?" (Rosa, 42 anos)
}

A vivência do luto pelo filho idealizado consiste em delicado processo de adaptação à criança real. Cabe lembrar, conforme postulado por Stroebe e Schut (1999), que as pessoas enlutadas tendem a oscilar entre "momentos orientados para a perda" e "momentos orientados para a restauração" - e que essa oscilação é um processo regulador, saudável e necessário que continua através do tempo. O ideal é que não se estagne nem nos movimentos voltados para a perda, nem tampouco nos voltados à restauração. Baseando-nos na proposta dos autores, podemos pensar que, ao longo da vida, os pais passarão por esse enfrentamento diante de momentos decisivos para a vida do filho surdo, como a escolha da modalidade de comunicação, o uso dos recursos tecnológicos, a definição de uma escola especializada ou não, dentre outros. Ao longo dessas experiências, existirão momentos em que estarão mais voltados para a perda - tendo que lidar com a dor e a tristeza de ter um filho diferente do padrão da sociedade -, e outros em que estarão voltados para a restauração - para o ajustamento da vida, tendo que dar conta das tarefas, buscando aprender mais sobre a surdez e a reconstrução de uma nova identidade enquanto pais de filhos surdos. Cabe ainda destacar a importância da 
vivência do luto, das emoções e sentimentos decorrentes deste, dentro dos limites e possibilidades de cada um, como uma oportunidade dos pais de ressignificarem o diagnóstico e criarem recursos para lidar com a realidade.

\section{O ideal do filho falante}

Após a confirmação do diagnóstico de surdez, os pais vivenciam um longo processo para a aceitação de um filho diferente do esperado. Nesse processo, observamos que a concepção e o significado da surdez para os pais ouvintes influencia diretamente a aceitação da mesma e as possibilidades de intervenções e estratégias comunicativas, terapêuticas e educacionais escolhidas por estes, como, por exemplo, o oralismo, bilinguismo e o uso ou não de AASI ou IC (Oliveira, Cúnico, Cunha, Kruel \& Tochetto, 2013; Silva, Zanolli \& Pereira, 2008; Teixeira, Paiva \& Lima, 2015). Esta categoria aborda a relação entre concepções, percepções e sentimentos sobre a surdez e as escolhas que os pais ouvintes privilegiam para o filho surdo. No relato dos pais, evidencia-se que metade dos entrevistados apresenta uma compreensão mais patológica da surdez, demonstram muita dificuldade na aceitação da condição clínica dos filhos e desejam a "cura" da deficiência. Nesses casos, o IC aparece como um dos principais meios de viabilizar a "cura". Os pais enfatizam o desejo de que seus filhos possam falar o português em sua modalidade oral, apesar de reconhecerem o impacto positivo do aprendizado de Libras e afirmarem sentir muita satisfação com o desenvolvimento e com a comunicação do filho.

Em muitos relatos, foi possível perceber uma aproximação da concepção clínico-terapêutica da surdez, compreendendo a mesma como uma deficiência, marcada pela falta da audição e, muitas vezes, referida como um "problema" que a criança tem (Skliar, 1998).

“(...) mesmo que ela tenha esse problema de audição, pra mim também não mudou em nada (...) eu vou encarar, é minha filha. E eu, assim, opto assim. Não é por causa dessa deficiência que eu vou diminuir ela, entendeu? Pelo contrário, vou ajudar mais! O que eu puder ajudar, o que puder fazer pra melhora dela, eu vou fazer, entendeu? (Ana, 37 anos)

“(...) ele surpreende por ele ter essa dificuldade, esse problema. Olha ele até que é muito mais esperto do que meu filho mais velho era nessa época, sabia?” (Josias, 44 anos)

“(...) e ele tem um bom relacionamento, né, com as outras pessoas que têm o mesmo problema que ele." (Marcos, 32 anos) 
“(...) aí quando a mulher lá falou pra mim o que que ele tinha [diagnóstico de surdez] eu fiquei... anestesiada... mas, ao mesmo tempo, um pouco aliviada porque era aquele o problema, era aquele o problema. E eu sou meio assim, eu tenho um problema e eu vou em busca da solução, não fico muito focada no problema, não. E foi isso que eu fiz, na hora eu só queria resolver." (Mara, 29 anos)

Observamos uma dificuldade em compreender a surdez para além da perda auditiva. As crianças surdas ainda têm sua identidade construída a partir do referencial ouvinte, sendo consideradas como deficientes, alguém que está em desvantagem em relação ao mundo. Dessa forma, necessitam de assistência para suprir a falta de audição, fazê-las ouvir de forma semelhante e, assim, se inserirem no mundo, de tal modo que a surdez passa a ser vista como um "problema a ser resolvido" (Bisol \& Sperb, 2010; Skliar, 1998).

Nesta perspectiva, a surdez representa uma quebra do narcisismo parental e a perda do ideal projetado no filho (Asano, Neme \&Yamada, 2010). Corroborando aos achados de diversos estudos (Asano, Neme \& Yamada, 2010; Yamada, Moretti, Prado \& Bevilacqua, 2014; Bittencourt \& Montagnolli, 2007; Stelling, Stelling, Santos Torres \& Castro, 2014), os resultados encontrados nesta pesquisa apontam que os pais se mostram tristes, frustrados, sobrecarregados e apresentam diversas preocupações com relação ao sucesso, à aceitação social e à independência dos filhos surdos. Estes são fatores que podem dificultar a aceitação do diagnóstico de surdez do filho.

Nesse processo, os pais manifestam o desejo de conduzir o filho de volta à normalidade, o que, nesse primeiro momento, está relacionado a escutar. Como todos os filhos dos entrevistados possuem perda neurossensorial bilateral profunda a severa, o uso do AASI não traz os ganhos significativos que os pais desejam. Desta forma, as expectativas recaem sobre o IC.

"Com o implante eu acho que é mais rápido dela ouvir, entendeu, dela ouvir, interagir. Porque eu vejo outras crianças implantadas e vi que é bom! (...) Pra ela ouvir e aprender. Ela aprende a língua e bem rápido. Imagina se ela ouvisse. Ia crescer bem mais, evoluir bem mais!" (Ana, 37 anos)

"Eu que decidi. Eu e Deus. Eu falei assim vou fazer esse implante porque um dia ele vai cobrar a mim. O que eu tiver de fazer com o Gabriel, eu vou fazer. Então no dia que ele crescer ele vai dizer 'a minha mãe correu atrás disso pra mim sabendo que eu poderia um dia escutar'. É o futuro do meu filho, cara, depende de mim pra ele escutar alguma coisa um dia. E vai escutar em nome de Jesus." (Rosa, 42 anos)

“(...) a gente ficou com aquela expectativa dele poder fazer as coisas dele e tal, que ele vai começar a escutar, vai poder ir logo pra escola regular. Que eu tenho essa esperança, né?" (Josias, 44 anos) 
“(...) você vai vendo relatos das pessoas, 'ah meu filho faz isso', "meu filho hoje terminou a escola', então você vê que tem uma esperança, entendeu? Implantado, né? O surdo, surdo eu já não sei, assim, talvez termine e tudo mais, mas com uma dificuldade” (Marcos, 32 anos)

O IC é visto por esses pais como algo capaz de curar a surdez da criança, possibilitando que esta se desenvolva de forma semelhante a qualquer outra criança ouvinte. Mesmo afirmando terem recebido informações de que este dispositivo não restaura a audição - apenas fornece a sensação da audição à criança com perda auditiva com a qualidade necessária para a percepção dos sons, não se comparando a qualidade auditiva do ouvinte (Costa, Bevilacqua \& Amantini, 2005) -, a maioria dos entrevistados apresenta altas expectativas, permeadas por ideias equivocadas e fantasiosas com relação a esse recurso tecnológico. Para Asano, Neme e Yamada (2010), o IC representa a possibilidade de uma restituição narcísica para os pais, o resgaste do filho idealizado. As autoras pontuam ainda que a esperança depositada na implantação parece permitir a negação parcial das dificuldades que os pais devem enfrentar com a confirmação do diagnóstico.

Dos entrevistados, em três casos os filhos já realizaram a cirurgia de IC e, em outros três, os filhos estão na fila de espera. Somente um pai, que descobriu recentemente a surdez, não mencionou sobre essa possibilidade; e uma criança não pode fazer o procedimento devido à má formação na cóclea. O processo de reabilitação após o implante coclear é lento e, por vezes, muito doloroso para a criança e para a família. Das crianças usuárias do IC, duas fizeram o procedimento há cerca de um ano, um período muito restrito para o progresso da habilitação. Somente uma criança implantou há mais tempo (quatro anos) em apenas um dos ouvidos. Apesar dos resultados incipientes e/ou aquém dos esperados pelos pais, estes relatam satisfação e esperança.

“(...) até o Alan começar a eu ver algum resultado, um ano depois, tipo, eu só fui ver o resultado do Alan quando ele tava com três anos, três anos e meio, eu chamava 'Alan', ai ele começava a repetir as coisas, começava a balbuciar, era um recém-nascido, o que a gente fala é que o tempo dele de idade auditiva dele é de uma criança de três anos, ele tem seis, ele é bebê, entendeu? Mas tem que ter calma..." (Mara, 29 anos)

"A expectativa é que consiga escutar, primeiro escutar. Porque escutar, vamos dizer, ele já está escutando, só que pouco. Mas ele ainda não compreende. O importante pra mim é ele conseguir se comunicar. E aí conseguindo se comunicar, conseguindo ter a vida dele normal, aí vou ficar feliz já. A qualidade de vida dele é mais importante, não só a comunicação." (João, 29 anos)

“(...) ele ainda não tá falando bem e tem essas coisas que só depois eu pensei que ele vai ter que tirar o aparelho pra tomar banho, pra nadar, pra... aí a cabeça girava, né? Como é que ia ser o futuro dele e tal... mas hoje eu imagino que com isso agora o Antônio tem 
completamente condições de ser independente, pô, tô super animado até com o desenvolvimento dele. Até pouco tempo ele ainda falava 'papai' e 'mamãe', quase a mesma coisa, era 'tatá' e 'tatá', e tatá servia pra mamãe e pra papai. E hoje ele sabe diferenciar um pouco mais 'papai', 'mamãe', mas já responde bem, tá ouvindo, tá ajustando o volume do aparelho, entendeu? E a gente tá progredindo bem, ele tá progredindo bem e a gente tá muito animado, eu tô super animado!" (Josias, 44 anos)

É possível ver a satisfação com os resultados já obtidos com o implante, mesmo que ainda muito limitados e pouco produtivos para as crianças. Isto parece possibilitar uma melhor perspectiva por parte dos pais em relação ao futuro dos filhos, gerando esperança e entusiasmo. Conforme assinala Asano, Neme e Yamada (2010), “o implante coclear não é só para o filho. É também para as mães” (p. 232). No entanto, os entrevistados também relataram sentir muita angústia e ansiedade no momento de tomada de decisão pelo implante, mencionaram ainda cansaço e sobrecarga com o processo de habilitação e preocupação com relação às questões financeiras para manutenção do aparelho. Apesar das possíveis vantagens que o implante possa trazer, este pode gerar um aumento no nível de stress, ansiedade e angústia nos pais devido ao doloroso processo de implantação e adaptação ao IC (Zaidman-Zait, 2008; Yamanaka, Paiva e Silva, Zanolli \& Paiva e Silva, 2010).

Nesse processo da busca pela normalidade, outro aspecto que aparece em todos os relatos é o intenso desejo de que o filho "fale", considerando a expressão oral da linguagem.

\footnotetext{
"Ele é uma criança normal, esperta... só não fala ainda. Mas, se Deus quiser, agora com o implante vai falar!” (João, 29 anos)

"[narrando sobre a $1^{a}$ consulta com a fono] eu fui logo perguntar se ele ia falar... meu medo é um dia ele não falar. Eu vou ficar nessa preocupação de... pô, eu creio que ele vai falar, mas se ele não falar, amém! Mas eu creio que ele vai falar, nem que ele não fale tipo normal, mas alguma coisa que dê para entender pelo menos... que ele consiga falar, entendeu? Esse é meu maior medo, entendeu?" (Rafael, 23 anos)

"O meu desejo é, o meu desejo é que ela venha oralizar, que ela venha... pra mim vai ser... bom, também eu quero recursos, entendeu, eu quero a melhora pra ela, eu quero ver ela falar." (Ana, 37 anos)
}

Um dos grandes desafios após a confirmação do diagnóstico do filho referese à escolha da modalidade de comunicação. Pelo fato de os pais serem ouvintes, é esperado que estes optem pela fala, forma habitual de interação na sociedade ouvinte (Oliveira, Cúnico, Cunha, Kruel \& Tochetto, 2013). Na maioria dos casos, com exceção de uma criança que ainda não entrou na escola, todos os filhos tiveram acesso à língua de sinais. Os pais descrevem com satisfação os avanços através do contato com essa modalidade de comunicação. 


\begin{abstract}
"Olha, eu agradeço a Libras (...) e nesse tempo ele aprendeu, ele ficou mais calmo porque a gente já conseguia se comunicar, ele começou a se comunicar, eu entendia o que ele queria, porque antes ele: 'tanana' e eu não entendia. Ai ficava nervoso, começa a bater porque eu falava 'É esse aqui, filho?', às vezes ele tava pedindo água, a gente tá aqui comendo, mas ele tá pedindo água, mas eu não sabia o que ele queria. Aí quando foi lá pro colégio que ele começou a ter a... a língua, né, de Libras, pô, ele se acalmou demais, trouxe muita calmaria pra ele..." (Mara, 29 anos)

'Mudou muito. Bom ele falava, 'bom' [representando a palavra em sinais] e agora eu sei o que é a palavra bom. E assim vai indo, né, a tranquilidade, graças a Deus, no meu lar reinou porque assim, tinha hora que eu dizia assim, 'meu Deus, o que essa criança tem?'. Ele antes chorava, chorava, chorava e eu não entendia nada. E hoje não, é a blusa? aí faz assim [representa o sinal da blusa]. Hoje não, ele vai lá e já faz os sinais todos. Aí ele vai lá, pega a blusa." (Rosa, 42 anos)
\end{abstract}

"Quando veio pra cá [escola especializada] ela só sabia gritar, era nervosa... que a gente mesmo não entendia, mas depois que a gente começa a aprender a Libras a gente começa a ficar mais tranquila, que a gente vai ter a resposta, a gente se entende." (Ana, 37 anos)

$\mathrm{Na}$ fala dos entrevistados, é possível perceber a satisfação com a possibilidade de os filhos conseguirem um meio de se comunicar. Por meio da língua de sinais, o diálogo entre eles passou a existir de forma eficaz, com uma compreensão mútua. Além do desenvolvimento que a Libras possibilitou para as crianças, os pais ressaltam também a modificação no comportamento, usando frequentemente adjetivos como mais "calmo" e "tranquilo". No entanto, mesmo reconhecendo o impacto positivo no desenvolvimento do filho e na comunicação entre eles, com exceção de uma mãe, a maioria dos pais enfatiza o desejo pela oralização.

“(...) ah, 'mas você já não estuda Libras?’ Já, mas hoje eu não posso estar aqui, hoje eu tô aqui, amanhã eu não posso estar, então eu tenho que preparar minha filha para o mundo." (Ana, 37 anos)

"E ele está na fono pra aprender a falar. Libras pra mim vem em segundo plano. Assim, ele vai ter que aprender para poder se comunicar, é... como posso falar.... ele é surdo e vai ter que aprender a falar Libras, né? Pra se comunicar só com os outros surdos.” (João, 29 anos)

“(...) ele consegue se comunicar, assim, ele se vira, eu sei que os surdos também se viram lá na mímica deles, mas ele tem que esperar a outra pessoa saber também, não adianta você fazer Libras... eu ficar fazendo Libras pra você e você não sabe o que é Libras, entendeu? Porque a minha maior preocupação era inserir o Alan no mundo, porque o mundo, a gente vive no mundo, o mundo é cruel." (Mara, 29 anos)

De acordo com as falas dos entrevistados, a oralização aparece como principal meio de minimizar as dificuldades de inserção social. É curioso observar que a utilização da Libras pode despertar nos pais sentimentos ambivalentes. Ao mesmo tempo em que realiza o desejo de ver o desenvolvimento do filho, por outro 
lado, concretiza e reafirma a diferença do mesmo (Bittencourt \& Montagnolli, 2007). Razões estas, dentre outras, que levam os pais a resistirem ao aprendizado desta forma de comunicação ou a aprenderem de forma insuficiente e, ainda, a manifestarem o desejo de que os filhos possam falar Libras só entre os surdos e que o português seja falado em casa - apontando para o fato de que a principal questão não está relacionada à comunicação em si e à escolha da melhor modalidade linguística para o filho, mas sim, à busca pela normalidade do filho baseada na concepção do padrão ouvinte. Isto reflete a dificuldade de os pais investirem no filho que nasceu surdo. Diante da constatação de que a criança não terá a audição igual às outras crianças ouvintes, os pais abrem mão do projeto de ter um filho ouvinte e passam a investir no ideal do filho falante (Carvalho, J., 2000). Barcellos (2011) aponta que as mães parecem imaginar que, se os filhos falarem, poderão afastá-los da deficiência, buscando assim o filho ideal da sociedade ouvinte.

\section{(Des)conhecimento da surdez e sua influência nos cuidados parentais}

A família vivencia diversos sentimentos ao descobrir a surdez do filho, como medo, raiva, culpa e tristeza. Muitas vezes, essas reações e sentimentos podem ser intensificados devido ao desconhecimento, à desinformação e/ou às concepções errôneas acerca da surdez, o que pode gerar dificuldades na interação com a criança. A forma pela qual os pais enfrentam a surdez influenciará na capacidade para se reestruturar e desenvolver um ambiente de trocas e interações significativas, que favoreça o desenvolvimento pleno do filho surdo (Bittencourt \& Montagnoli, 2007; Yamashiro \& Lacerda, 2016; Paula \& Pereira, 2014; Oliveira, Cúnico, Cunha, Kruel \& Tochetto, 2013; Stelling, Stelling, Santos Torres \& Castro, 2014; Trindade, 2017). Esta categoria aborda a relação entre o conhecimento e a concepção de surdez e o processo de aceitação dos pais ouvintes. A partir dos relatos dos entrevistados, evidenciou-se que um dos obstáculos enfrentados pelos pais ouvintes na interação com os filhos surdos está relacionado à falta de conhecimento sobre a perda auditiva, tanto dos pais quanto da sociedade. A desinformação, as falsas crenças e ideias em relação à pessoa surda e o preconceito dificultam o desenvolvimento de interações familiares mais saudáveis. 
Todos os entrevistados relataram que não tinham convivência com pessoas surdas até então e que desconheciam as especificidades da surdez, descrevendo a angústia, tristeza, desorientação e preocupação como provenientes da falta de informações.

\footnotetext{
"Não, sabia nada (...) não tinha contato com ninguém com isso, não sabia nada e a gente ficou muito agoniado sem saber o que fazer.” (Rafael, 23 anos)

"Eu fiquei triste, eu fiquei muito triste, assim, porque eu não sabia nada sobre surdez, né??" (Cláudia, 34 anos)

“(...) a gente ficou perdido... são sabia nada, nada... nós não tínhamos ninguém próximo que conhecesse, que sabia...." (Marcos, 32 anos)
}

A surdez é compreendida pelos pais como uma doença e, muitas vezes, associada a transtornos mentais.

\begin{abstract}
"Você logo pensa, pô, meu filho é surdo, não vai conseguir nada, vai ficar vegetando, vai depender de mim pra tudo (...) e depois que a gente soube da surdez dele, só apareceu pessoas, assim, para confortar meu coração e eu falar assim, 'pô, meu filho vai ser alguma coisa!'. Ele não vai depender de alguém fazer alguma coisa por ele, eu não vou ter que ficar botando um prato de comida para ele, ficar assim, fazer tudo por ele, né?" (Rafael, 23 anos)

"Porque a minha preocupação era 'pô, ele não vai ter uma vida normal', eu nunca conheci um surdo, então, pra mim eu achava que tipo, surdo ficava em casa, dependia de mãe, não
\end{abstract} podia sair, não podia fazer nada, entendeu?" (Mara, 29 anos)

"Porque assim, no começo, eu achava que ele tinha algum problema de cabeça, eu achava, porque assim, porque ele... quando ele começava a chorar, ele chorava sem parar, sem parar (...) Aí quando ele [pai] soube ele falou que não queria, não ia aceitar um filho doido. Eu falei, meu filho não é doido, não." (Rosa,42 anos)

É interessante observar a visão distorcida sobre a surdez e sobre as potencialidades da pessoa surda demonstrada pelos entrevistados. Inicialmente, os pais referem-se aos surdos como incapazes de se desenvolver em sua totalidade. Para Falkenbach, Drexsler e Werler (2008), é comum os pais apresentarem inúmeras fantasias sobre o fato de gerar uma criança com deficiência. Tais fantasias são fundamentadas, muitas vezes, em preconceitos em relação à deficiência, que pode ser vista pela sociedade como relacionada a pessoas dependentes, apáticas e improdutivas. As autoras pontuam que a imagem do deficiente como incapaz pode dificultar a aceitação da criança pelos seus pais. Ao associar a perda auditiva a uma doença, anomalia ou incapacidade, muitos pais sentem-se inconformados, frustrados e culpados (Trindade, 2017; Yamada, Moretti, Prado \& Bevilacqua, 2014). Dessa forma, perdem a noção de que a criança tem muitas outras 
potencialidades além de ouvir e falar o português (Silva \& Gonçalves, 2013), dificultando a interação e o investimento no filho que nasceu.

Ao discorrerem sobre as percepções acerca da surdez e da pessoa surda, alguns pais descrevem-nas a partir de características comportamentais apresentadas pelos filhos surdos como, por exemplo, a irritabilidade, associando a surdez a tais aspectos.

“(...) porque surdo é tudo nervoso, né? Ele no início só sabia gritar, era todo nervosinho.” (Marcos, 32 anos)

"Ah, mas o Alan era uma criança muito nervosa, muito nervosa. Tudo gritava. E eu pensava que era por causa disso [a surdez](...) mas depois eu entendi que o nervosismo dele era porque ele não conseguia se comunicar, então, tudo ele ia lá e 'pum', batia.', (Mara, 29 anos)

Muitas vezes, as crianças surdas que têm pouco domínio de uma língua ou que não compartilham a mesma língua dos pais, apresentam sentimentos de raiva e ficam nervosas e irritadas por não conseguirem estabelecer comunicação e interação consistentes com seus pais, familiares e amigos (Goldfeld, 2002; Witkoski, 2009; Silva, 2010). Os pais apresentam dificuldades em perceber que este comportamento acontece devido às dificuldades comunicativas entre eles. Desse modo, parecem atribuir à surdez essa reatividade da criança, referindo-se a esta como agressiva, teimosa e nervosa. No entanto, conferir tais adjetivos à personalidade do surdo pode gerar como consequência a rotulação, sugerindo que essas características são inerentes à surdez (Teixeira, Paiva \& Lima, 2015).

Os relatos apontam ainda que os pais apresentam muitas preocupações, medo e insegurança quanto ao presente e ao futuro da criança.

"Aí eu falei 'meu filho não vai poder estudar, o que que vai ser do meu filho, né?", (Marcos, 32 anos)

"Não deixo ela sozinha um instante e nem com ninguém. Ela só sai comigo ou com o pai, ela só fica aonde o irmão tá, porque eu sou meio... preocupada demais com ela, né, por ela ser surda. E assim... é, eu acho... assim, surdo, por mais que eu sei Libras e ela também, a gente vê tanta coisa ruim acontecendo, eu tenho medo, assim, acontecesse alguma coisa com ela e ela não me falar por medo, a gente vê tanta... aí... né? "' (Cláudia, 34 anos)

"Só que com ela é diferente, né? Por ser surda, tem que ter mais cuidado. Eu não deixo ela com ninguém... nem todo mundo está preparado pra cuidar de criança surda, né, então não vai ter aquela atenção. E tem o medo de deixar e de ser maltratada, até mesmo por não falar o que aconteceu..." (Ana, 37 anos)

“(...) infelizmente nós pais temos essa mania, né, de tirar um pouquinho do foco das outras coisas e transferir tudo só pra ele, né? Demos menos atenção, um pouco, ao meu filho mais velho pra poder dar a ele por causa desse diagnóstico." (Josias, 44 anos) 
A fase após a confirmação do diagnóstico se torna muito difícil, conflituosa e incerta devido ao desconhecimento da surdez, suas repercussões e possibilidades de suporte. Os pais não sabem o que esperar do filho com relação à fala, à comunicação e à socialização, por exemplo, gerando muita angústia, medo e ansiedade devido à constante preocupação (Vieira, Bevilacqua, Ferreira \& Dupas, 2012; Oliveira, Cúnico, Cunha, Kruel \& Tochetto, 2013). A insegurança dos pais quanto à autonomia e à independência dos filhos surdos é ainda mais acentuada frente à escassez de políticas públicas que os apoiem nas diferentes fases de sua vida (Bittencourt, Mendonça \& Silva, 2011).

Importante destacar também a influência da atitude do profissional de saúde e de educação no momento de informar sobre a perda auditiva. Estudos apontam que, muitas vezes, estes profissionais apresentam pouco preparo, passando falsas esperanças ou sendo extremamente pessimistas, enfatizando a deficiência e as incapacidades da criança; e, por vezes, apresentam informações limitadas, pouco claras e confusas (Silva, Zanolli \& Pereira, 2008; Paula \& Pereira, 2014; Trindade 2017). Muitos pais em nosso estudo afirmam não terem recebido informações sobre o que é a surdez e suas possibilidades de reabilitação logo após a notícia de que o filho é surdo. Alguns afirmaram que pesquisaram na internet informações sobre o assunto, principalmente as mães. Cabe ressaltar que, ao longo do desenvolvimento da criança, independentemente da complexidade e da compreensão das informações recebidas, novas dúvidas surgirão em relação ao desenvolvimento do filho surdo. Diante disso, os pais necessitam de profissionais habilitados e capacitados para que possam recorrer conforme surjam questões ou preocupações específicas (Falkenbach, Drexsler \& Werler, 2008).

Destacamos também outro ponto interessante nos relatos. É esperado, ao longo do desenvolvimento da criança, que os pais tenham uma dedicação mais intensa nos primeiros anos de vida da criança e que, posteriormente, incentivem mais a autonomia dos filhos. No entanto, os entrevistados descrevem um cuidado constante e continuado, e até comportamentos de superproteção ou "mimos", devido ao fato de o filho ser surdo. Segundo Augusto e Chacon (2011), esse é um comportamento comum nos pais de filhos surdos, que apresentam essa atitude como uma tentativa de ajudar o filho a superar os obstáculos e as limitações da surdez. No entanto, conforme apontam Oliveira e Poletto (2015), o resultado pode ser inverso, com a maximização da deficiência e maior dependência dos cuidados 
parentais. As autoras destacam também que esse comportamento frequentemente tem por motivação, mesmo que de forma inconsciente, tornar-se indispensável para o filho, podendo ainda confluir em uma relação de dependência mútua.

Outra importante questão trazida pelos participantes do estudo, relacionada ao desconhecimento da surdez, diz respeito às situações de preconceito vivenciadas pelos mesmos.

"E eu perguntei 'A senhora tá rindo por quê?!', ai ela... fisionomia dela caiu na hora, 'não é que...', eu falei 'ela não tá fazendo palhaçada não, ela só é surda', ai eu falei 'a minha filha também é surda', ai ela olhou pra minha filha assim... ela tava rindo porque a Joana [senhora surda] tava gesticulando comigo e ela tava achando aquilo engraçado, mas não era engraçado, ela tava falando, se comunicando." (Cláudia, 34 anos)

“Ai uma vez na rua a mulher 'nossa, ela é tão linda... tadinha... mas é surda, né?!', isso aí acaba comigo. Isso aí eu vivencio muito isso na rua, né? Como ela vem, às vezes, no ônibus fazendo Libras. E eu falei assim 'ah, mas pra ser surdo tem quer ser feia a criança? Surdo tem que ser feio?' Ai a mulher ficou olhando pra minha cara assim, não teve reação..." (Cláudia, 34 anos)

"E ela é louca por balé, né? Ela ama balé, ama balé, e assim, ai eu fui lá, né, tentar matricular ela no balé e a professora não quis, por ela ser surda, e a professora teve preconceito, falou assim 'Ah, mas ela não escuta, ela vai fazer balé por quê?!'” (Cláudia, 34 anos)

"Porque na família do pai dele também tem gente preconceituosa. Porque assim, quando ele... ele ia assim, pra casa das tias, todo mundo chamava ele de maluco. 'Ah, surdo pra mim é maluco". Ai é um preconceito, né? (...) também não deixava brincar com ele. A tia não deixava os primos brincar com ele só porque é surdo," (Rosa, 42 anos)

“Ai a criança tá lá brincando perto do Alan, não sei o que... Ai, às vezes, é criança pequenininha, ai vem 'ih, mamãe, o menino tá bem usando um negócio preto na cabeça, mas pra que que é aquele negócio preto na cabeça dele? É pra ouvir música?', aí mãe 'não, não é pra ouvir música, não. Ó, não brinca com ele, não porque senão pode quebrar... não fala com ele, não'. Aí manda a criança sair de perto, entendeu? Os pais mesmo não sabem, não tem informação daquilo e não passa direito pra criança, entendeu? (...) É, desconhecimento geral, só que muitos pegam e falam assim pra criança 'Ó, então não brinca com ele não, ó, brinca ali', entendeu? Só que, assim, às vezes não sabe nem que eu sou a mãe, mas eu tô do lado e tô ouvindo, entendeu? É essas que eu falo que o adulto é pior, porque a criança tá ali, às vezes você consegue chegar até a criança e você explicar. " (Mara, 29 anos)

Os relatos envolvendo situações de preconceito no cotidiano dos pais são frequentes e, em sua maioria, ocorrem pelo desconhecimento da sociedade em relação à surdez. Percebemos, através dos relatos, que os surdos ainda são identificados com foco na deficiência, vistos como incompletos e incapazes, sendo estigmatizados e desqualificados. O olhar estigmatizado e discriminatório, as risadas que acontecem possivelmente devido à sua forma de comunicação diferente, o desconhecimento das condições e dos potenciais da pessoa surda reforçam a exclusão dos surdos (Witkoski, 2009, 2017; Quevedo, Dambrós \& Sassi, 2017). 
Diante da dificuldade de inclusão social, a frustração, a raiva e a tristeza que os pais vivenciam tornam doloroso o processo de aceitação do diagnóstico de surdez do filho (Bittencourt \& Montagnolli, 2007; Witkoski, 2009, 2017; Falkenbach, Drexsler \& Werler, 2009). Por outro lado, Bittencourt e Montagnoli (2007) propõem que os pais atribuem parte de seu sofrimento à discriminação e ao preconceito advindos da sociedade como forma de aliviarem seus conflitos relacionados à culpa e à vergonha pela não aceitação do filho surdo.

Ter um filho surdo é uma experiência única para os pais ouvintes que se deparam com um universo totalmente novo. A aceitação do diagnóstico de surdez pode ser um processo longo e difícil, devido à influência de diversos fatores, como o desconhecimento, tanto dos pais, quanto da sociedade, sobre a surdez. O aparecimento de dúvidas e preocupações, as crenças e imagens distorcidas sobre a surdez, o preconceito e a falta de apoio e informações dificultam o relacionamento dos pais com seus filhos surdos.

\section{Rede de apoio na surdez}

Diante da complexidade da parentalidade com um filho surdo, a rede de apoio pode se tornar um dos elementos de suporte para os pais ouvintes. Em diversas áreas do conhecimento, a rede de apoio assume a importância como uma das fontes essenciais de proteção individual, familiar e comunitária. Brito e Koller (1999) definem a rede de apoio social como um conjunto de sistemas e de pessoas significativas que integram os elos de relacionamento recebidos e identificados do indivíduo. O apoio social pode ser compreendido como qualquer informação e/ou auxílio material, oferecidos por essa rede, que resultem em efeitos emocionais e comportamentos positivos (Valla, 1999). A presente categoria aborda a importância da rede de apoio social após o diagnóstico de surdez. Os entrevistados narram que as relações familiares, os grupos de pais e o apoio das instituições de saúde e educacionais oportunizaram recursos psicológicos e materiais de forma a melhorar suas competências para lidar com a perda auditiva do filho, amenizando seus sofrimentos, angústias e dúvidas.

A família tem seu papel de destaque no fornecimento de apoio emocional, afetivo e instrumental. 
"Ih, a família do pai dele me abraçou, me abraçou mesmo, minha comadre, os meus excunhado, todos me abraçaram. Ó, não faltava nada pra ele. 'Ó, Rosa, precisando de ir no médico', 'ó, precisando disso e daquilo, fala com a gente, entendeu'. A família até hoje apoia muito. Todos eles! Tão aprendendo Libras. Quando eles vão pra aniversário, levam ele. 'Rosa, ó, vamos com o Gabriel tal hora na festa, eu passo aí pra buscar ele'. Onde eles vão, carregam o Gabriel." (Rosa, 42 anos)

"Eu tenho minha família. Tem minha mãe, minhas irmãs e meu pai. Ele é aposentado já, então ajudam a gente em tudo, fica sempre ele [filho]. Ele me dá esse suporte físico, né?" (Marcos, 32 anos)

“A família, meu círculo de primeiro grau ali, é minha fortaleza. Todo mundo me apoia. É onde quando eu tenho dificuldade eu peço e eles ajudam, eles perguntam tudo, eles me ajudam. Meu irmão, meu pai e algumas primas próximas sempre me ajudaram." (João, 29 anos)

Bittencourt, Françozo, Monteiro e Francisco (2011) afirmam que a rede de relacionamentos oferece uma malha de proteção social, atuando em diversos campos, como na provisão de cuidados instrumentais (o cuidado das crianças, divisão de tarefas e ajuda financeira), de orientação, de incentivo e apoio emocional, corroborando os achados dessa pesquisa. $\mathrm{O}$ apoio do cônjuge aparece de forma relevante na constituição dessa malha, sendo um elemento estruturante para o parceiro, à medida que esse incentiva, dialoga e divide as responsabilidades em relação às decisões sobre o filho.

\footnotetext{
"Ah, eu falo tudo com o Beto [marido], a gente discute tudo sempre. Igual eu agora quero colocar ele [filho] no inglês. Aí o Beto 'Pô, Mara tu não acha que tá muito cedo pra botar ele no inglês? A gente tem que ensinar ele, mas calma... vamos deixar ele crescer mais'. Aí eu 'tá bom'. Ainda não botei, mas mais tarde eu vou colocar porque eu vejo assim não gosto de ficar diferenciando ele, porque ele é tanto capaz quanto uma criança ouvinte" (Mara, 29 anos)

“(...) nós demos apoio um pro outro, estamos juntos em tudo... é... nós abraçamos mesmo essa situação juntos” (Josias, 44 anos)

“(...) a minha esposa que me ajuda, passa algumas coisas e me ensina os sinais pra mim conseguir falar com o Pedro” (Marcos, 32 anos)
}

A vizinhança, os colegas de trabalho e outros círculos de amizades também apareceram nos relatos dos entrevistados como grande fonte de suporte emocional, financeiro, no cuidado da criança, propiciando uma interação social positiva.

“(...) e as crianças lá da comunidade, que ele joga futebol lá, já sabem Libras por causa dele. Ele fala assim 'Jogar futebol' [sinalizando] e eles respondem. E o professor, eles lá da comunidade arrumaram um professor pra ficar junto do outro, pra ajudar, porque o professor mesmo não sabe Libras. Aí o auxiliar sabe Libras e passa tudo pro Gabriel." (Rosa, 42 anos)

"Poxa e os meus amigos, eu falo muito com eles também... no começo quando eu descobri foi dificil, foi dificil... eles me ajudaram." (Marcos, 32 anos) 


\begin{abstract}
"Nós tivemos um tempinho ainda no escuro, sem saber direito como seria, se iríamos fazer mesmo esse implante ou não, né? E como a gente poderia procurar pra fazer esse implante? Até que uma amiga da minha esposa falou pra gente que tinha, que tava sendo realizado implantes aqui na instituição, né? Falou que tinha no Fundão e em São Paulo." (Josias, 44 anos)
\end{abstract}

Todos os entrevistados mencionaram a presença fundamental de uma rede de apoio social e afetiva, sejam elas da família ampliada, de amigos ou pela comunidade em geral. Uma rede de apoio eficiente pode atuar como um redutor de estresse para os pais de crianças com necessidades especiais (Brito \& Dessen, 1999). Em nossa pesquisa, as ações exercidas por essa rede através da companhia, da disponibilidade para ouvir, do auxílio nas tarefas e financeiro, do acesso às informações e do aprendizado da língua de sinais, parecem repercutir na autoestima dos pais, amenizar o preconceito, contribuir para a solução de alguns problemas e para a redução do estresse e solidão. Cabe ressaltar ainda a importância dessa rede quando há ausência de uma figura parental, como ocorreu com três entrevistados.

Outro importante elemento da rede de apoio mencionado pelos entrevistados é o grupo de pais, frequentado em sua maioria pelas mães, que se reúne informalmente na instituição especializada em surdez na qual os filhos de cinco participantes estudam. Este centro educacional tem como regra a frequência semanal dos pais em aulas de Libras, que conta com a participação de professores surdos e psicólogos. O contato semanal possibilita aos pais o aprendizado da língua de sinais e, também, um espaço de troca de informações e experiências. Além da frequência às aulas, por ficarem a maior parte do tempo (6-7 horas) na escola esperando os filhos nas atividades escolares e assistências terapêuticas, as mães se reúnem praticamente todos os dias em uma sala exclusiva concedida pela instituição para ficarem durante o tempo de espera. Este contato e as trocas diárias durante as aulas de Libras e nos encontros informais na sala de espera permitiram a criação de um senso de grupo, ao qual os entrevistados se referem como o "grupo de mães". Os participantes da pesquisa destacaram a relevância deste grupo como facilitador e como suporte.

\footnotetext{
“Venho pra cá também converso muito com as mães, as mães também são pacientes, ajudam... E as mães passam no mesmo processo que as outras. Tá todo mundo no mesmo barco. Mãe de 20 anos, mãe de quase 30 anos, mãe de 18, de 20, e tá tudo ali. Que as antigas que já tá aqui já tá bem paciente. E esse contato faz, muita diferença, porque é bom, é... você sai daqui, é... radiante, né? (....) se eu não trazer nada pra mim almoçar, nada pra mim comer, que eu fico às vezes o dia todo, as mães aqui não deixa você ficar sozinha, não. 'Vêm, você não trouxe pão? Não foi comprar? Vem, senta aqui, vem cá,
} 
vamos compartilhar aqui, então'... É porque é uma cada aqui ajudando a outra, uma aqui ajudando a outra." (Ana, 37 anos)

“As mães dão maior apoio, uma ajuda a outra aqui! Que até o ano passado, minha mente não era muito... assim, no momento que ele entrou aqui, minha mente era muito fechada (...) porque assim, ai eu ficava parada aí elas 'Rosa, seu filho já tem benefício?' Eu falei, 'Não. Eu tenho direito?' e elas 'Tem!'. Eu conversava com elas, aí elas abriam mais minha mente, sabe? Que era um pouco fechada a minha mente.” (Rosa, 42 anos)

A importância de receber o apoio vindo de outras mães foi reconhecida, tanto pelas mulheres que frequentam o grupo, quanto pelos pais cujas esposas participam deste, que explicam que esse contato diário possibilita o compartilhamento de sentimentos e experiências e, também, trocas de informações e orientações sobre recursos sociais. A identificação mútua entre as mães promove solidariedade aos que enfrentam situações similares e torna-se reconfortante para as mães mais fragilizadas (Guarinello \& Lacerda, 2007; Ribeiro, Yamada \& Tavano, 2007). As relações estabelecidas parecem proporcionar vínculos sólidos e seguros.

Este grupo informal, constituído por esses pais, parece proporcionar um espaço terapêutico, uma vez que oferece trocas, orientação e acolhimento. A potencialidade que estes encontros possuem, poderia ser mais explorada pela instituição através da criação de grupos terapêuticos estruturados para os pais ouvintes. Sobre grupos terapêuticos para pais de surdos, diversos estudos descrevem a importância destes como recurso para os familiares (Bittencourt, Françozo, Monteiro \& Francisco, 2011; Guarinello \& Lacerda, 2007; Quevedo, Dambrós \& Sassi, 2017). Apontam que esse apoio e compartilhamento de experiências podem amenizar o sofrimento e as dificuldades em relação ao diagnóstico, gerar maior envolvimento dos pais, permitindo a construção de um significado mais positivo em relação à surdez e a melhor percepção do filho surdo. Tais aspectos contribuem significativamente para o relacionamento dos pais com a criança e para a aceitação da surdez.

O papel da instituição escolar como rede de apoio é marcante. Observamos nos relatos desses pais, cujos filhos estudam nessa escola especializada em surdez, a valorização dessa instituição. As ações dos profissionais habilitados que trabalham nessas instituições estão voltadas para o aprendizado de estratégias de desenvolvimento e de potencialidades da pessoa surda, como medidas educacionais, assistências terapêuticas e sociais. Além disso, todos os serviços específicos que a instituição oferece são gratuitos, como as atividades para os pais 
(curso de Libras e oficinas) e o programa educacional e assistencial para as crianças. Esta ação ocupa papel central no suporte emocional, afetivo e financeiro dos entrevistados. Esses dados vão ao encontro dos resultados da pesquisa realizada por Barbieri, Broekman, Souza, Lima, Wernet e Dupas (2016) que, ao investigarem a experiência de pais de filhos deficientes visuais, observaram que a participação dos pais nas atividades em uma instituição especializada é uma experiência essencial, além de proporcionar o convívio com outras pessoas que vivenciam situações semelhantes.

O contato com surdos adultos que obtiveram bom desempenho profissional também foi apontado por alguns entrevistados como rede de apoio para a família, fazendo emergir sentimentos de esperança nos pais em relação à educação e à competência do filho.

"Ah, elas [professoras surdas de Libras] interagem muito bem, tem seus diplomas. Então, como que o surdo não tem capacidade pra isso? A gente vê que tem e muita!” (Ana, 37 anos)

“(...) hoje tem surdo ai que tem três, quatro faculdades. Os professores da minha filha mesmo, a professora da minha filha é professora de educação física, é personal trainer e é professora de Libras. Ah, já fez pós-graduação, né? São os exemplos que eu tenho, assim, né, tenho três professores, assim que são meus exemplos, assim que o surdo é capaz de tudo." (Cláudia, 34 anos)

Adultos surdos podem se tornar importantes modelos socioculturais e linguísticos, o que, além de contribuir significativamente para o desenvolvimento da criança surda, também pode melhorar a experiência das famílias (Dizeu \& Caporali, 2005; Strobel, 2009). A convivência dos pais ouvintes com surdos adultos possibilita aos pais acesso a muitas informações e pode melhorar a comunicação, aceitação e prover maior conhecimento acerca da surdez e das possibilidades do filho. Os pais que contam com essa importante rede de apoio podem aumentar a sensação de bem-estar (Benedict \& Sass-Lehrer, 2009; Dizeu \& Caporali, 2005; Hintermair, 2000; Sass-Lehrer, 2012; Strobel, 2009).

Como parte da rede social especializada com que os pais ouvintes contam, encontram-se os profissionais de saúde e escolares, em sua maioria, médicos otorrinolaringologistas, assistentes socias, fonoaudiólogos, psicólogos e professores. Esta rede de relacionamento desenvolve um papel no âmbito assistencial, educacional e terapêutico. 
"Sim, foi, foi... ele [otorrino] falou "olha, vai pra escola, bota ela na escola lá de libras, de língua de sinais, é bom, ela vai melhorar bastante, vai aprender, vai se comunicar melhor com você"... entendeu? E... eu ouvi ele." (Ana, 37 anos)

“(...) quando confirmou, eu falei assim... ai eu olhei pro médico e falei assim, 'Doutor, eu vou fazer o que, né? Ele é surdo. Eu achava que ele escutava, mas e agora?' Ele falou assim, 'Tu sabe que que é Libras, minha filha?' e eu falei assim 'Nunca vi, eu acho que eu já ouvi falar, bem longe, mas já ouvi falar'. Aí ele, 'Não tem como você fazer um curso de Libras, não? Pra você se aperfeiçoar, pra falar com o seu filho'. E ele mesmo me indicou que tinha esse colégio aqui." (Rosa, 42 anos)

"Eu tive muito apoio, quando eu entrei aqui na escola, da assistente social. Muito dos cartões, essas coisas assim do meu filho, ela que deu entrada, ela que ajudou, entendeu? Porque eu tentava... eu, sem experiência, eu tentava pelo celular, não conseguia." (Rosa, 47 anos)

"Vou te falar, aqui [instituição de saúde aonde o filho realizou o implante] foi minha salvação. Salvação que eu falo, assim, eles me acolheram demais, acolheram demais o Alan, lá eles tão muito proativos a ajudar, a ajudar, assim, pô, tentar correr atrás pra você, esclarece tudo pra você." (Mara, 29 anos)

Os profissionais da área de saúde e escolar parecem proporcionar contextos que permitem orientação e acesso a informações, amenizando as dúvidas e preocupações. Bittencourt, Françozo, Monteiro \& Francisco (2011) enfatizam a importância do papel dos profissionais como parte integrante da rede de apoio, afirmando que a condução e a intervenção por sua parte devem ter como objetivo fortalecer e aumentar os recursos de enfrentamento dos pais para lidar com o diagnóstico.

Contudo, uma situação recorrente nas falas dos entrevistados foi a insatisfação com relação à demora e à precariedade dos serviços de saúde e dos recursos públicos.

\footnotetext{
"Ai de lá os médicos fizeram o encaminhamento pro SUS [Sistema Único de Saúde]. Aí solicitou um otorrino de implante e isso demorou uns 4 meses pra sair a vaga dele. Aí a gente foi lá, ele pediu a ressonância e a tomografia. Aí o exame foi o que mais demorou. A tomografia na época estava quebrada lá no hospital e a ressonância lá não tinha. E eu tive que correr atrás. E foi por isso tudo que demorou mais ainda pra sair.” (João, 29 anos)

"E também tratamento assim.... acesso a médico e essas coisas, pra conseguir alguma coisa é tudo longe ou demora pra atendimento. Mas eu sei que isso é pra todo mundo, não é só pra quem é surdo." (Marcos, 35 anos)
}

Diversas foram as situações em que os pais relataram se sentir negligenciados pelos serviços de saúde, sendo destacada a dificuldade de acesso aos serviços especializados; a espera prolongada para conseguir as consultas e a realização dos exames médicos para a confirmação do diagnóstico e para a realização do IC; e a falta de informações e esclarecimentos sobre os benefícios e auxílios concedidos aos surdos e seus familiares. Bittencourt, Françozo, Monteiro 
\& Francisco (2011) apontam que, de fato, a rede de recursos sociais, representada pelos direitos e benefícios sociais, tem se mostrado insuficiente. Os autores explicam que essa rede tem funcionado como fonte de proteção social, principalmente no que se refere aos benefícios concedidos às pessoas com deficiência, mas não de forma absoluta. Na maior parte dos casos, tudo depende do esforço e da persistência daqueles que requerem benefícios ou direitos.

Nos momentos de dificuldades, no enfrentamento do diagnóstico de surdez do filho, os pais podem acessar uma rede de relacionamentos e de recursos sociais na tentativa de encontrar ferramentas que os auxiliem a lidar com a nova realidade. $\mathrm{O}$ apoio dos familiares, amigos, profissionais de saúde e das instituições escolares e de saúde foram os recursos mais citados. Em suas narrativas, os pais atribuem grande importância ao apoio recebido e mostram-se satisfeitos. A rede social, portanto, cumpre o papel de apoio e proteção social, no sentindo de proporcionar mais qualidade de vida para a criança surda e seus pais (Bittencourt, Françozo, Monteiro \& Francisco, 2011).

Cabe ainda destacar a multiplicidade e a consistência que compõem a rede de apoio dos entrevistados. Mesmo quando se queixam de não ter o apoio familiar, por exemplo, relatam a presença de amigos, grupos de mães e até a instituição como alternativa com a qual podem contar. De acordo com Brito e Koller (1999), a rede de apoio social é considerada um dos aspectos determinantes para a resiliência. Nesta perspectiva, podemos pensar que a boa qualidade da rede encontrada neste estudo contribuiu para a resiliência dos pais e para a promoção da saúde de todos os membros da família.

\section{Tornando-se pais resilientes}

O nascimento de uma criança surda em uma família ouvinte traz consigo um novo e desafiante universo para os pais. Conforme visto nas categorias anteriores, são inúmeras as situações que repercutem de forma positiva ou negativa no exercício da parentalidade. Nesta última categoria, abordam-se a percepção dos pais quanto à experiência de ser mãe e de ser pai de um filho surdo e a resiliência na vivência da parentalidade. O discurso dos entrevistados é marcado pelo pesar e pelas dificuldades enfrentadas, principalmente com relação ao foco em torno da 
habilitação e da comunicação do filho. No entanto, revelou-se também o poder de superação e capacidade dos pais diante da experiência de se adaptar aos cuidados de um filho surdo, o que resultou, para muitos, em uma oportunidade de transformação. Afirmaram que se tornaram pessoas mais fortes, melhores e mais sensíveis ao outro. Neste aspecto, ressalta-se a capacidade de resiliência e enfrentamento dos entrevistados, bem como a possibilidade de extraírem algum sentido para a experiência de tornarem-se pais de um filho surdo.

No primeiro momento, após a confirmação do diagnóstico do filho, o foco de cuidado dos pais parece ser totalmente voltado para a assistência à criança, especialmente para as mães.

\begin{abstract}
"O diagnóstico... mudou em relação à nossa vida, assim, minha esposa teve que parar de trabalhar pra dar mais atenção a ele, né? Ficamos vendo o tratamento dele.... E hoje, mesmo depois desse diagnóstico dele, nós estamos conduzindo tudo legal, focando na assistenciazinha dele, né?" (Marcos, 32 anos)
\end{abstract}

“(...) aí, depois, quando eu descobri a surdez, ai eu fui atrás de fono, fui pra outros lugares, tive que andar atrás de médico pra ela, então assim, mudou a minha vida totalmente. Eu deixei de viver a minha vida pra viver a vida dela, entendeu? Na verdade, até hoje eu deixo de viver a minha vida, pra viver pra ela. Eu sempre penso primeiro nela, depois... na verdade, a família toda gira em torno dela, eu vejo isso." (Cláudia, 34 anos)

“Eu era estoquista de fábrica... Aí eu falei, vou abrir mão, né, pra recuperação da minha filha. Aproveitar a minha filha. Então eu parei (...) pedi as contas e vim cuidar da minha filha. Eu optei pra me dar pra ela. Ocupar meu tempo pra ela. Eu me entrego pra minha filha e às coisas dela, entendeu? De médico em médico, eи ocupo meu tempo com ela, vou pra escola, pra mim é ótimo, E porque também a minha vida é pra isso! Pra viver aqui com ela." (Ana, 37 anos)

"Eu sou mãe do Alan em tempo integral... essa é minha profissão agora [risos]" (Mara, 29 anos)

É esperado que, nesse primeiro momento, a família fique com a atenção voltada unicamente para a assistência à criança, pois tudo gira em torno da tentativa de melhora do quadro clínico (Guerra, Dias, Ferreira Filha, Andrade, Reichert \& Araújo, 2015). Este fato é observado principalmente nos relatos das mães. Todas as entrevistadas são exclusivamente dedicadas aos cuidados com o filho(a), e muitas abdicaram de seus empregos e carreiras para acompanhar a criança nas atividades escolares e terapêuticas. Os dados encontrados corroboram a literatura que aponta a mãe como a pessoa principal nos cuidados diretos da criança surda (Mahl, Nóro, Zanini, Kessler \& Biaggio, 2013; Yamada \& Valle, 2014; Longato-Morais, Prado \& Yamada, 2017). Cabe mencionar ainda que a maioria das mães relata cansaço, sobrecarga e estresse diante da intensa rotina do filho. Conforme observam Yamada 
e Valle (2014) e Mahl, Nóro, Zanini, Kessler e Biaggio (2013), essa concentração das responsabilidades na figura da mãe pode gerar sobrecarga mental e física e acarretar dificuldades na relação conjugal, na vida profissional, social e financeira, comprometendo inclusive a saúde, uma vez que estão mais propensas a desenvolver altos índices de tensões emocionais e estresse.

A confirmação do diagnóstico exige dos pais uma série de mudanças e adaptações para que haja uma adequação dos pais às necessidades próprias da criança surda.

“(...) mas foi um choque, assim, de realidade, né? Que eu vivia acho que ali no meu mundinho, com a minha vidinha ali, aí eu tive um filho surdo, eu nem vinha pra esses lados de cá, ficava só pelo meu bairro, trabalhava lá mesmo... ficava no meu mundinho ali e aí eu tive que... aí, depois, quando eu descobri a surdez, aí eu fui atrás de fono, eu fui pra outros lugares, tive que andar atrás de médico pra ela, então assim, mudou a minha vida totalmente." (Cláudia, 34 anos)

“(...) e estamos vendo para ano que vem já mudar pra cá, ela [esposa]quer vir pra zona norte porque é muito cansativo ir e vir todos os dias. Aonde eu moro é um ótimo lugar, porém, o transporte público é muito ruim. E aqui, o transporte público pra cá já é um pouco melhor..." (Marcos, 32 anos)

“(...) ai logo veio, minha esposa trouxe esses papéis do alfabeto em Libras, ai uns... tudo mudou, né? Falei, não, essa agora é minha vida, então rapidinho, rapidamente eu comecei a decorar essa linguagem, o alfabeto..." (Josias, 44 anos)

A chegada de um filho surdo não implica somente em adaptações internas, mas interfere nos papéis, nos hábitos, nos padrões familiares e no aprendizado de uma nova cultura e de uma nova forma de comunicação. Desse modo, implica em uma adaptação e reorganização da família. Conforme assinalam Oliveira, Simionato, Negrelli \& Marcon (2004), esse período de adaptação exige da família flexibilidade para lidar com essas mudanças; a depender da estrutura familiar e das características de cada membro, este pode ser um período mais longo e difícil.

Nesse contexto, a comunicação aparece no relato de todos os entrevistados como um dos maiores desafios desse processo.

\footnotetext{
“A comunicação é muito mais complicada. É um mundo novo pra mim. Eu não sei como fazer... por exemplo, a minha sobrinha ela também não gostava de andar de mão dada, mas se ela fosse lá na frente andando e ficasse muito longe, eu assoviava e ela olhava pra mim. Pro Lucas não, eu não consigo avisar pra ele. Ou seja, quando eu fico com ele eu tenho que ficar muito atento, olhando tudo. Como eu faço pra explicar pra ele pra ficar aqui? Eu tenho que esperar passar o carro pra mostrar. É um mundo totalmente diferente do que eu já vivi. Muito complicado..." (João, 29 anos)

"A nossa comunicação tá longe de ser perfeita, é muito complicado... e a gente faz, a gente tenta aprender, mas a gente tá longe da perfeição, é muito difícil, né, mas a gente tenta fazer com que ele se comunique o máximo possível” (Marcos, 32 anos)
} 


\begin{abstract}
"Às vezes a gente querer passar algo pra ele, eu ainda não poder falar com as minhas palavras, assim, ele entender o que eu quero ali num momento, Às vezes ele quer alguma coisa também e às vezes eu demoro a entender... e é uma coisa que tinha que ser uma coisa rápida, né? A comunicação, né, tá sendo o maior desafio. E ele mesmo, na hora dele brincar com pessoas, crianças ouvintes e tal, ele ter... né, as crianças não terem aquela paciência com ele, ai é ruim, isso deixa a gente frustrado um pouco, mas são coisas que a gente vai... vamos passando essas dificuldades." (Josias, 44 anos)
\end{abstract}

À exceção de uma criança que está entrando agora na escola, os filhos dos entrevistados se comunicam através da Libras. No entanto, observamos que os pais aprenderam Libras de forma insuficiente e a comunicação com os filhos se dá, na maioria dos casos, por uma articulação entre sinais, mímicas e fala. De acordo com os relatos, as interações e trocas comunicativas parecem ocorrer de forma superficial, corroborando os achados de diversas pesquisas (Canho, Neme \& Yamada, 2006; Stelling, Stelling, Santos Torres \& Castro, 2014; Yamashiro \& Lacerda, 2016). Cabe ressaltar que a ausência de experiências e de trocas comunicativas significativas entre os pais e o filho surdo podem se tornar um obstáculo ao estreitamento dos laços afetivos, além de ter repercussões no desenvolvimento da criança (Yamashiro \& Lacerda, 2016; Neuber, Valle \& Palamin, 2008; Stelling, Stelling, Santos Torres \& Castro, 2014).

No entanto, diante destas dificuldades, os entrevistados desenvolveram maneiras específicas para lidar com a situação.

\footnotetext{
"Mas as cores, né, algumas cores eu já sei... é isso... Aí eu tô me adaptando um pouco, tô pra tirar um... eu pego muito informações pelo Youtube, né, de sinais e tal." (Josias, 44 anos)

"E tem a cadernetinha dela, eu boto lá na sala, boto no quarto, mostro, ela sabe o que que é... como se fosse um livrinho que eu fiz, assim, tem assim, eu entendo o que que é banheiro, os outros não, mas aí eu mostro lá, o banheiro, o vaso, a pia, o que ela quer. Aí ela vai lá e aponta o que ela quer. Outro exemplo, quer a mamadeira, leite, aí eu mostro pra ela, boto lá a cozinha, ela vai lá e mostra... pra mim ela faz os sinais, mas pra quem não sabe ela mostra na cadernetinha." (Ana, 37 anos)

“(..) então, lá em casa eu boto nome nas coisas. Na geladeira tá escrito 'geladeira' na frente pra ela saber que aquilo ali é uma geladeira. O banco eu boto colado assim 'banco', pra ela saber que aquilo ali é banco. O armário eu escrevo, eu fiz no computador 'armário', pra ela saber que aquilo ali, que o nome daquilo ali é armário. E então eu estimulo ela cada vez mais, né? Eu dou... assim, eu complemento. Então, eu posso falar por mim, pela minha filha, porque a minha filha aprende, mas tudo é através também, assim, a familia tem que abraçar o surdo, né?" (Cláudia, 34 anos)
}

Apesar do desejo e da expectativa dos pais em relação à fala, eles apresentam formas criativas e utilizam diversos recursos para se comunicar com o filho, encontrando diversas maneiras de enfrentar as dificuldades surgidas. Dessa 
forma, os pais experienciam com alegria os pequenos avanços dos filhos, dando importância ao que consideram positivo e às possibilidades de crescimento.

“(...) e hoje eu, não só do comportamento do Antônio, mas desenvolvimento dele, os progressos deles, coisas pequenas que a gente... 'ah, isso ai qualquer criança sabe e tal', mas cada vitoriazinha, cada conquistazinha dele a gente já vibra pra caramba, hoje... né?!" (Josias, 44 anos)

"E agora a gente chama e ele já olha. Isso tem sido muito bom pra gente, né? Cada pouco que a gente vai vendo melhoras nele a gente vai 'cara, legal!'” (Mara, 29 anos)

Falkenbach, Drexsler e Werler (2008), ao estudarem a vivência de mães com filhos deficientes, pontuam que a aceitação e o enfrentamento da nova realidade permitem aos pais experimentar mais amor, compreensão e ternura com os filhos. As autoras observam que é recompensador para os pais quando conseguem perceber os pequenos avanços de seu filho. Pontuam que até mesmo avanços considerados mínimos, que por vezes não são percebidos nas experiências com os outros filhos, ganham destaque, sendo muito valorizados e considerados uma grande vitória nessa relação.

Outro aspecto que pode ser importante fonte de apoio no processo de aceitação de ter um filho surdo é a espiritualidade, apontada no relato de duas mães.

"Porque a gente sem religião, nós não somos ninguém. (....) minha mãe ensinou a ter muita fé em Nossa Senhora. Aí sempre falava assim, intercede, pede pela intercessão de Nossa Senhora que é Mãe de Jesus, que é mãe, que ela intercede por nós e tudo dá certo. " (Rosa, 42 anos)

"O futuro do meu filho, cara, depende de mim pra ele escutar alguma coisa um dia. E ele vai escutar em nome de Jesus. E eu to pedindo pra Deus, se Deus falar não, pra mim é não. Se Deus tocar no meu coração, sim, então é sim” (Rosa, 42 anos)

"[relatando sobre como conseguiu a vaga na instituição] Eu fiquei o dia todinho aqui, a manhã todinha esperando pra ver se abria uma vaguinha e eu fiquei, boto uma fé em Deus que eu vou sair daqui e eu vou conseguir, 'ô, Jesus, me ajuda'. Porque tudo eu boto Deus

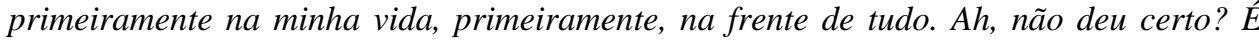
porque não tinha que dar, porque Deus achou que não era bom, não era bem pro meu filho. Ai eu sei que aqui eu consegui" (Rosa, 42 anos)

“(..) mas no início nesses meses eu fiquei pensando assim... aí eu fui pra igreja também que eu sou evangélica, fui procurar orientação com Deus pra vê se eu colocava ela nessa escola. Naquele primeiro momento que eu aceitei, que eu falei 'não, eu vou levar ela, vou... sou forte, eu vou! Deus vai me dar forças" (Cláudia, 34 anos)

“(...) eu mato um leão todo dia, eu agradeço a Deus, quando eu vou dormir eu falo 'Deus, brigada por mais um dia vencido'. É, é uma luta, só ele mesmo para me dar forças" (Cláudia, 34 anos)

A fé em Deus apareceu no relato dessas mães como um suporte para lidar com as dificuldades e as especificidades da surdez, assim como para aumentar o 
sentimento de aceitação e esperança por acreditar em algo melhor para o futuro do filho. A relevância da espiritualidade tem sido destacada em pesquisas sobre a experiência de pais com filhos deficientes e com doenças crônicas, mostrando a sua influência na resiliência das famílias, uma vez que parecem contribuir significativamente para que o grupo familiar desenvolva processos de fortalecimento e superação diante das adversidades (Barbieri, Broekman, Souza, Lima, Wernet \& Dupas, 2016; Chequini, 2007; Dezoti, Alexandre, Freire, Mercês \& Mazza, V. A, 2015; Vilhena et al., 2014; Walsh, 2005).

O relato dos pais evidencia mudanças na forma de olhar para os filhos e de enfrentar a situação da surdez.

\begin{abstract}
"Ah, é maravilhoso... É maravilhoso, eu falo assim, a minha vida mudou depois que eu fui mãe da Bárbara, né? Que você passa a ver muitas outras coisas, você passa a enxergar o mundo diferente, assim coisas que passavam despercebidas por mim, hoje não passam, né? (...) nossa, acho que me mudou da água pro vinho! Assim, que eu era uma antes dela e hoje eu sou outra, né? Com mais responsabilidade, com outra visão, visão pelo próximo, eu tenho outra visão da vida, acho que de tudo...." (Cláudia, 34 anos)
\end{abstract}

"É maravilhoso, a minha filha é tudo que eu esperava, assim ela me cobre esse vazio, ela me deixa assim, madura, eu amadureci, eu tive esses três filhos, mas a maioria, os três filhos que eu tive, não amadureci tanto, como ela. Assim com ela foi diferente, porque eu parei a minha vida e os outros eu tinha que trabalhar pra até mesmo sustentar. Então, eu tinha aquela obrigação e chegava em casa cansada e no outro dia levantava pra ir pro trabalho de novo. Então, eu não tive muito aquele afeto de mãe, não, aquele cuidado, aquela coisa, porque tinha outras pessoas que fazia por mim. Mas ela eu vi que não tinha como... porque uma coisa é você lidar com uma pessoa que fala, que escuta, outra coisa é você lidar com uma criança que é surda e depende de você, então aí mudou a minha maturidade. Ah, me transformou numa pessoa melhor, mais pacífica, mais compreensiva, mais mãe, ela me transformou assim, que eu não esperava a minha atitude ser assim..." (Ana, 37 anos)

"Realmente, é como você... hoje em dia eu olho longe, a gente consegue enxergar uma formiguinha lá, é coisa que a gente não ia ver nunca, coisa que a gente deixava passar despercebida e que temos visto agora. Somos mais humanos, né, o Antônio veio pra deixar a gente mais humano, mais... eu vi que todo mundo é igual, isso aí, a surdez, né, não tem classe, não tem cor, as pessoas... eu vejo até pessoas em boas situações de vida e tal, passando o mesmo problema que a gente, tendo as mesmas dificuldades que a gente, problema eu não digo mais problema, né? As mesmas dificuldades. E a gente se adaptando muito bem, né? O Antônio não é um problema, o Antônio é a vitória nossa, a gente recebeu ele com muita alegria, eu volto a falar, não queria outro filho." (Josias, 44 anos)

Nesta perspectiva, os pais parecem reconhecer na surdez dos filhos uma oportunidade para crescerem e se tornarem pessoas e pais melhores. Relatam, ainda, sobre aprendizagens, amor e o respeito ao outro. Emergiram, nas narrativas dos entrevistados, novas possibilidades de ser com o filho surdo. De acordo com Walsh (2005), a resiliência é "a capacidade de renascer da adversidade fortalecido e com mais recursos. É um processo ativo de resistência, reestruturação e crescimento em 
resposta à crise e ao desafio" (p. 4). Destacamos a capacidade de resiliência dos entrevistados, que não ficaram estagnados na dor e nas dificuldades. Os pais demonstraram interesse em aprender e obter cada vez mais informações sobre a surdez, relatando um contínuo esforço para buscar o melhor para os filhos. 


\section{Considerações finais}

Nosso estudo teve como objetivo compreender a vivência da parentalidade com um filho surdo a partir de um estudo de campo. Constatamos que ter um filho surdo é uma experiência desafiadora para os pais ouvintes que se deparam com um universo totalmente novo, se constituindo em um complexo e delicado processo de aceitação e de enfrentamento desta realidade. Sem a pretensão de responder de forma conclusiva a esta questão, apresentaremos a seguir algumas considerações desta pesquisa que ganharam relevância.

Inicialmente, a confirmação da surdez parece afetar a interação e as trocas afetivas com o filho surdo, configurando uma relação mais distanciada, descrita pelos pais com grande pesar e permeada por sentimentos ambivalentes. Eles relatam dificuldade na aceitação da surdez, que pode ser vista desde as primeiras suspeitas do diagnóstico e no enfrentamento dessa realidade após a confirmação, principalmente devido à imprevisibilidade da situação e ao desconhecimento acerca da surdez.

Neste contexto, cabe mencionar a importância do diagnóstico precoce e a situação alarmante da saúde pública no país, pois, apesar de os entrevistados terem a confirmação do diagnóstico de maneira precoce, considerando a realidade brasileira, chamou atenção o fato de que há cinco entrevistados cujos filhos não realizaram o "Teste da Orelhinha" ao nascer. Conforme apontado na discussão teórica, apesar da obrigatoriedade do exame para crianças nascidas em todos os hospitais e maternidades do país, percebemos que o mesmo não tem sido realizado, ocasionando o diagnóstico tardio, o que pode gerar prejuízos significativos no desenvolvimento da criança.

Os resultados obtidos apontaram que os pais compreendem a surdez a partir de uma perspectiva mais patológica, marcada pela perda auditiva e pela visão preconceituosa da deficiência. Dessa forma, a chegada de um filho surdo se configura num momento muito difícil para esses pais, pois o filho real é muito diferente do idealizado e sonhado. Assim, eles vivenciam um grande pesar e frustração, o que dificulta o processo de luto natural que é esperado no nascimento de qualquer criança. Observamos, no relato dos entrevistados, diversas reações, 
como o choque e a negação, que revelam o grande impacto da notícia para os pais; e também sentimentos como a tristeza e a culpa. Os pais apresentam dificuldade em lidar com a criança que não nasceu "normal" e "saudável", gerando inclusive um distanciamento nas interações com o filho.

Cabe destacar a importância da vivência do luto, das emoções e sentimentos decorrentes deste, dentro dos limites e possibilidades de cada um, como uma oportunidade de os pais ressignificarem o diagnóstico e criarem recursos para lidar com a realidade. Compreendemos ainda que, ao longo da vida, passarão por esse enfrentamento diante de momentos decisivos para a vida do filho surdo, tais como a escolha da modalidade de comunicação, o uso dos recursos tecnológicos, a definição de uma escola especializada ou não, dentre outros.

Outra questão significativa observada foi a tentativa dos pais de retomarem a "normalidade" do filho. Em um primeiro momento, o IC aparece como um dos principais meios de viabilizar a "cura" da surdez. No entanto, os pais percebem que este recurso não vai possibilitar audição igual a das crianças ouvintes, o que faz com que, em um segundo momento, busquem incessantemente pela oralização, desejando uma fala idealizada que é muito difícil de ser adquirida pelos filhos surdos. Isto acarreta, entre outras questões, um aprendizado insuficiente de Libras por parte dos pais, apesar de reconhecerem o impacto positivo do aprendizado desta língua para o filho e afirmarem sentir muita satisfação com o desenvolvimento e a comunicação da criança. Dessa forma, a comunicação entre eles e o filho surdo acontece de forma superficial para ambos, gerando mais frustração e descompasso nessa interação, apontando para a dificuldade dos pais em investirem no filho que nasceu surdo, permanecendo na busca pelo filho ideal da sociedade ouvinte.

O desconhecimento dos pais acerca da surdez e das potencialidades da pessoa surda evidenciou-se como um dos obstáculos enfrentados pelos pais ouvintes na interação com os filhos surdos. Podemos perceber que a desinformação, as crenças distorcidas em relação à pessoa surda e o preconceito dificultam o desenvolvimento de interações familiares mais saudáveis. Importante pensarmos ainda que o discurso médico sobre a surdez reforça os aspectos negativos da mesma e, dessa forma, a pessoa surda é negligenciada em relação a seu potencial e capacidade. Todos esses elementos reforçam a insegurança e a preocupação dos pais com relação ao desenvolvimento linguístico, escolar e profissional do filho, dificultando a aceitação da surdez e a interação com o filho. Ressaltamos a 
necessidade de os profissionais de saúde e das escolas conhecerem de forma adequada a surdez e as potencialidades dos surdos, para que possam passar aos pais todas as informações necessárias para o desenvolvimento da criança surda.

Um aspecto deste estudo que chamou atenção foi a importância da rede de apoio formada por familiares, por amigos, pela comunidade em geral, pelo grupo de mães e pelas instituições de ensino e de saúde. Os relatos dos pais entrevistados apontam que estes elementos oportunizaram recursos psicológicos e materiais, de forma a melhorar a competência dos pais para lidar com o filho surdo, amenizando seus sofrimentos, angústias e dúvidas. Esse achado diverge da literatura pesquisada, que aponta pouca participação de uma rede efetiva e o sentimento de solidão desses pais.

Este estudo também revela que, apesar das dificuldades enfrentadas e do pesar inerente ao processo da surdez do filho, alguns pais puderam ressignificar a situação, extraindo algum sentido para a experiência de tornarem-se pais de um filho surdo, e aprenderam a valorizar as potencialidades da criança. Além disso, o poder de superação e a capacidade dos pais de adaptação aos cuidados de um filho surdo resultaram, para muitos, em uma oportunidade de transformação pessoal. Os pais relatam reconhecer na surdez dos filhos uma oportunidade para crescerem e se tornarem pessoas e pais mais fortes, melhores e mais sensíveis ao outro. Este foi um dos resultados mais surpreendentes do estudo.

É importante mencionar a dificuldade em atuar como pesquisadora, colocando em suspensão a minha prática clínica com surdos. Foi delicado, durante as entrevistas, me distanciar do meu lugar de psicóloga clínica de crianças e adolescentes surdos para poder ouvir sobre a experiência dos pais ouvintes. Percebi meu desconforto ao longo dos relatos, pois diversas vezes estava muito identificada com os surdos, ficando bastante crítica em relação ao processo de aceitação e enfrentamento dos pais quanto ao diagnóstico de surdez do filho. No entanto, ao longo das análises das entrevistas, pude notar o sofrimento, a angústia e as dores desses pais e, finalmente, pude dar lugar e voz a eles. Tive a oportunidade de ainda ser surpreendida com o potencial de saúde dos pais. A capacidade de resiliência e de crescimento e os recursos criativos que utilizam na interação com o filho surdo despertaram em mim um olhar mais sensível e cuidadoso para a vivência desses pais. 
Outro aspecto que consideramos importante destacar diz respeito a algumas limitações que este estudo encontrou, principalmente em relação à faixa etária dos filhos dos entrevistados e, também, ao fato de a maioria pertencer a uma mesma instituição escolar. A escolha em restringir para este período bem inicial do desenvolvimento infantil se deu para compreender a vivência desses pais desde os primeiros momentos desta realidade. No entanto, sugerimos que o estudo possa ser ampliado para surdos de outras faixas etárias. Vale ressaltar que, apesar de abordar a vivência dos pais ouvintes com filhos surdos, não se trata de uma realidade absoluta para todos os pais. No entanto, nos permitiu delinear considerações acerca da complexidade da experiência de ter um filho surdo e sua repercussão no exercício da parentalidade.

Percebemos como é difícil para os pais assimilarem a confirmação do diagnóstico de surdez do filho. A diferença significativa entre a criança idealizada e a real, que não nasceu "normal" e "saudável", consiste em um desafio para os pais, que apresentaram muitas dificuldades em aceitar o diagnóstico. Somado a isso, a compreensão da surdez como patologia e, neste cenário, o surgimento do IC, representando para os pais um meio de viabilizar a "cura" do filho, atuam também como dificultadores do processo de aceitação e enfrentamento, trazendo consequências para o exercício da parentalidade. Diante disso, é necessário um trabalho voltado não apenas à criança, mas também aos pais. É fundamental construirmos estratégias para promover acolhimento e orientação para os pais ouvintes, que muitas vezes ficam mobilizados e desorientados frente à criação de um filho surdo.

Esse estudo aponta para a necessidade de os pais contarem com a ajuda de profissionais que possam auxiliar na elaboração do seu luto e fornecer mais informações sobre a surdez, para que os pais possam ressignificar suas crenças e atitudes em relação ao filho surdo. Com este intuito, sugerimos a criação de grupos terapêuticos para os pais, principalmente nas instituições de saúde e educacionais especializadas, possibilitando aos pais um espaço de escuta, acolhimento e trocas de informações. Evidenciamos também a necessidade, diante dos poucos estudos sobre o tema, do desenvolvimento de novas pesquisas que tenham como objetivo maior aprofundamento do conhecimento na área de aconselhamento, acolhimento e intervenção junto aos pais ouvintes com filhos surdos. 
Gostaríamos de ressaltar, ainda, a importância de que não somente os pais, mas os profissionais da área da saúde e da educação, bem como a sociedade, possam refletir sobre suas concepções acerca da surdez. É preciso que o preconceito e as ações discriminatórias em relação aos surdos se modifiquem, para que os surdos possam, de fato, ter o direito de serem reconhecidos e respeitados nas suas diferenças.

Com este trabalho, pretendemos contribuir para uma melhor compreensão da surdez e da vivência dos pais ouvintes diante do nascimento de um filho surdo, colaborando para ampliar e fortalecer os recursos para aceitação da surdez do filho e, dessa maneira, auxiliar na interação dos pais com o filho surdo, bem como na vivência da parentalidade de uma forma mais ampla. 


\section{6 \\ Referências bibliográficas}

Alvarenga, K., Gadret, J., Araujo, E., \& Bevilacqua, M. (2012). Triagem auditiva neonatal: motivos da evasão das famílias no processo de detecção precoce. Revista da Sociedade Brasileira de Fonoaudiologia, 3(17), 241-247.

Amiralian, M. L. (1986). Psicologia do excepcional. São Paulo: EPU.

Amaral, L. A. (1995). Conhecendo a deficiência: em companhia de Hércules. São Paulo: Robe Editorial.

Asano, C., Neme, C., \& Yamada, M. (2010). Deficiência auditiva: estudos clínicos sobre o narcisismo materno. Boletim Academia Paulista de Psicologia, 78(1), 219-236.

Augusto, M. A., \& Chacon, M. C. (2011). Diferentes enfoques das relações familiares: superproteção e abandono. In Anais, 7 Encontro da Associação Brasileira de Pesquisadores em Educação Especial (pp. 1316-1327). Londrina, PR.

Barbieri, M. C., Broekman, G. V., Souza, R. O., Lima, R. A., Wernet, M., \& Dupas, G. (2016). Rede de suporte da família da criança e adolescente com deficiência visual: potencialidades e fragilidades. Ciência \& Saúde Coletiva, 21, 3213-3223. doi: 10.1590/1413-812320152110.19562016.

Barbosa, M. A., Chaud, M. N, \& Gomes, M. M. (2008). Vivências de mães com um filho deficiente: um estudo fenomenológico. Acta Paulista de Enfermagem, 21(1), 46-52.

Barcellos, C. (2011). Língua e linguagem no diálogo mãe ouvinte-filho surdo. (Dissertação de Mestrado). Universidade Federal de Santa Maria, Programa de Pós-Graduação em Distúrbios da Comunicação Humana, Santa Maria.

Bardin, L. (2011). Análise de conteúdo. São Paulo: edições 70.

Behares, L.E. (2000). Novas correntes da educação do surdo: dos enfoques clínicos aos culturais. Santa Maria: UFSM.

Benedict, S., \& Sass-Lehrer, M. (2009). Deaf and hearing partnerships: ethical and communication considerations. American Annals of the Deaf, 152(3), 275-82. doi: 10.1353/aad.2007.0023

Bentes, A., \& Hayashi, P.I. (2016). Normalidade, diversidade e alteridade na história do Instituto Nacional de Surdos. Revista Brasileira de Educação, 21(67). doi: 10.1590/S1413-24782016216744. 
Bevilacqua, M. C., Moret A. L. M., \& Costa, O. A. (2011). Conceituação e indicação do implante coclear. In M. C. Bevilacqua, M. A. N. Martinez, A. S. Balen, A. C. Pupo, A. C. M. Reis \& S. Frota (Orgs.), Tratado de audiologia (pp. 407-425). São Paulo: Santos.

Bittencourt, Z. Z. L. C., Françozo, M. F. C., Monteiro, C. R., \& Francisco, D. D. (2011). Surdez, redes sociais e proteção social. Ciência \& Saúde Coletiva, 16(1), 769-776. doi: 10.1590/S1413-81232011000700007.

Bittencourt, Z. Z. L. C., Mendonça, F. B., \& Silva, I. R. (2011). O que ele vai ser quando crescer? Expectativas de pais de crianças surdas. Medicina, 44(2), 185194.

Bittencourt, Z. Z. L. C., \& Montagnoli, A. (2007). Representações sociais da surdez. Medicina, 40(2), 243-249.

Bisol, C., \& Sperb, T. M. (2010). Discursos sobre a surdez: deficiência, diferença, singularidade e construção de sentido. Psicologia: teoria e pesquisa, 26(1), 7 ..

Bowlby, J. (2002). Apego e perda. São Paulo: Martins Fontes. (Trabalho original publicado em 1969).

Brito, A., \& Dessen, M. (1999). Crianças surdas e suas famílias: um panorama geral. Psicologia: Reflexão e Crítica, 12(2), 429-445. doi: 10.1590/S010279721999000200012.

Brito, R. C., \& Koller, S. H. (1999). Desenvolvimento humano e redes de apoio social e afetivo. In A. M. Carvalho (Org.), O mundo social da criança: natureza e cultura em ação (pp. 115-129). São Paulo: Casa do Psicólogo

Brunhara, F.\& Petean, E. (1999). Mães e filhos especiais: reações, sentimentos e explicações à deficiência da criança. Paidéia, 9(16), 31-40.

Bureau International d' Audiophonologie (BIAP). (1997). Classification audiométrique des déficiences auditives. Biap.org, 01 mai. 1997. Recuperado a partir de http://www.biap.org/index.php?option=com_content\& view $=$ article $\& i d=5 \% 3$ Arecommandation-biap-021-bis\&catid $=65 \% 3$ Act-2classification-des-surdites \&Itemid=19\&lang=en.

Buscaglia, L. (2002). Os deficientes e seus pais. Rio de Janeiro: Record.

Canho, P. G. M., Neme, C. M. B., \& Yamada, M.O. (2006). A vivência do pai no processo de reabilitação da criança com deficiência auditiva. Estud. psicol., 23 (3), 261-269. doi: 10.1590/S0103-166X2006000300005.

Capovilla, F. C. (1998). O implante coclear como ferramenta de desenvolvimento linguístico da criança surda. Journal of Human Growth and Development, 8(1-2), 74-84. doi: 10.7322/jhgd.38580. 
Carvalho, D. (2014). Literatura surda: o que é? Por uma teoria da literatura surda. Revista Diálogos, 2(2), 66-83.

Carvalho, D., \& Santos, L. (2016). Pais ouvintes, filho surdo: causas e consequências na aquisição da língua de sinais como primeira língua. Revista Sinalizar, 1(2), 190-203.

Carvalho, J. M. (2000). O ideal de completude narcísica e o adolescente surdo: um estudo clínico. (Dissertação de mestrado). Pontifícia Universidade Católica de São Paulo, Programa de Estudos Pós-Graduados em Fonoaudiologia, São Paulo.

Chequini, M. C. M. (2007). A relevância da espiritualidade no processo de resiliência. Psicologia Revista, 16(1/2), 93-117.

Colazza P., \& Anastasio, A. R. (2009). Screening, diagnosing and treating deafness: the knowledge and conduct of doctors serving in neonatology and/or pediatrics in a tertiary teaching hospital. São Paulo Medical Journal, 127(2), 6165. doi: 10.1590/S1516-31802009000200002.

Cortelo, F. M., \& Françozo, M. D. (2014). Ser pai de filho surdo: da suspeita ao enfrentamento. Psicologia em Estudo, 19(1), 3-11. doi: 10.1590/14137372189590001.

Costa, O. A., Bevilcqua, M. C., \& Amantini, R. C. B. (2005). Considerações sobre o implante coclear em crianças. In M. C. Bevilacqua \& A. L. M. Moret (Orgs.), Deficiência auditiva: conversando com familiares e profissionais da saúde (pp. 123-138). São José dos Campos: Pulso.

Dalzell, L., Orlando, M., MacDonald, M., Berg, A., Bradley, M., Cacace, A., ... Prieve, B. (2000). The New York State universal newborn hearing screening demonstration project: ages of hearing loss identification, hearing aid fitting, and enrollment in early intervention. Ear Hear, 21(2),118- 30.

Decreto ${ }^{\circ}$ 5.626, de dezembro de 2005. (2005). Regulamenta a Lei no 10.436, de 24 de abril de 2002, que dispõe sobre a Língua Brasileira de Sinais - Libras, e o art. 18 da Lei no 10.098, de 19 de dezembro de 2000. Diário Oficial da União, Brasília. Recuperado a partir de http://www.planalto.gov.br/ccivil_03/_ato20042006/2005/decreto/d5626.htm.

Dezoti, A. P., Alexandre, A. M., Freire, M. H., Mercês, N. N., \& Mazza, V. A. (2015). Social support to the families of children with cerebral palsy. Acta paul. Enferm, 28(2), 172-176. doi: 10.1590/S0101-73302005000200014.

Dias, T. R., Rocha, J. C., Pedroso, C. C., \& Caporali, S. A. (2001). A educação bilíngue de surdos: grupos de familiares. In 24 Reunião anual da Associação Nacional de Pesquisadores da Educação - ANPED. Caxambu, MG.

Dizeu, L. C., \& Caporali, S. A. (2005). A língua de sinais constituindo o surdo como sujeito. Educação e Sociedade, 26(91), 583-597. doi: 10.1590/S010173302005000200014. 
Falkenbach, A. P., Drexsler, G., \& Werler, V. (2008). A relação mãe/criança com deficiência: sentimentos e experiências. Ciênc. saúde coletiva, 13(2), 2065-2073.

Felipe, T.A. (2009). Libras em contexto - curso básico: livro do estudante. Rio de Janeiro: WalPrint.

Fonseca, C. (2015). Implante coclear: o que é? como funciona?. Direito de ouvir, 23 fev. 2015. Recuperado a partir de https://www.direitodeouvir.com.br/blog/ implante-coclear.

Franco, M. H. (2002). Uma mudança de paradigma sobre o enfoque da morte do luto na contemporaneidade. In M. H. Franco (Org.), Estudos avançados sobre o luto (pp. 15-38). São Paulo: Livro Pleno.

Frankl, V. E. (1989). Um sentido para a vida. São Paulo: Santuário. (Trabalho original publicado em 1978).

Freud, S. (1996a). Introdução ao narcisismo. In S. Freud, A história do movimento psicanalítico, artigos sobre a metapsicologia e outros trabalhos (Edição standard das obras psicológicas completas de Sigmund Freud, v. 14). Rio de Janeiro: Imago. (Trabalho original publicado em 1914).

Freud, S. (1996b). Luto e melancolia. In S. Freud, A história do movimento psicanalítico, artigos sobre a metapsicologia e outros trabalhos (Edição standard das obras psicológicas completas de Sigmund Freud, v. 14). Rio de Janeiro: Imago. (Trabalho original escrito em 1915 e publicado em 1917).

Geertz, C. (1989). A interpretação das culturas. Guanabara, RJ: Koogan.

Góes, F. (2006). Um encontro inesperado: os pais e seu filho com deficiência mental. Psicologia: Ciência e Profissão, 26(3), 450-461.

Goldfeld, M. (2002). A criança surda: linguagem e cognição numa perspectiva sociointeracionista. São Paulo, SP: Plexus.

Grinberg, L. (2000). Culpa e depressão. Lisboa: Climepsi.

Guarinello, A. C., \& Lacerda, C. B. F. (2007). O grupo de familiares de surdos como espaço de reflexão e de possibilidades de mudança. In A. P. Santana, A. P. Berberian, G. Massi \& A. C. Guarinello (Orgs.), Abordagens grupais em fonoaudiologia: contextos e aplicações. São Paulo: Plexus.

Guerra, C. S., Dias, M. D., Ferreira Filha, M. O., Andrade, F. B., Reichert, A. P. S., \& Araújo, V. S. (2015). Do sonho à realidade: vivência de mães de filhos com deficiência. Contexto Enferm, 24(2), 459-66. doi: 10.1590/010407072015000992014

Hintermair, M. (2000). Hearing impairment, social networks, and coping: the need for families with hearing-impaired children to relate to other parents and to 
hearing impaired adults. American Annals of the Deaf, 145, 41-51. Recuperado a partir de https://www.questia.com/library/journal/1P3-53852862/hearingimpairment-social-networks-and-coping-the

Honora, M., \& Frizanco, M.L. (2009). Livro ilustrado de língua brasileira de sinais: desvendando a comunicação usada pelas pessoas com surdez. São Paulo: Ciranda Cultural.

Houzel, D. (2004). As implicações da parentalidade. In L. Solis-Ponton (Org.), Ser pai, ser mãe. Parentalidade: um desafio para o terceiro milênio (pp. 47-51). São Paulo: Casa do Psicólogo.

Instituto Brasileiro de Geografia Estatística (IBGE). (2015). Pesquisa nacional de saúde 2013: ciclos de vida-Brasil e grandes regiões. Recuperado a partir de http://biblioteca.ibge.gov.br/visualizacao/livros/liv94522.pdf.

Costa, K. C. (2016). Etiologia da perda auditiva em neonatos diagnosticados em um programa de triagem auditiva neonatal (Dissertação de Mestrado). Faculdade de Ciências Médicas da Universidade Estadual de Campinas, Campinas, SP, Brasil.

Kelman, C. A., Silva, D. N. H., Amorim, A. C. F., Monteiro, R. M. G., \& Azevedo, R. M. G. (2011). Surdez e família: facetas das relações parentais no cotidiano comunicativo bilíngue. Linhas Críticas, 17(33), 349-365.

Kessler, T. M. (2008). A surdez que se faz ouvir: sujeito, língua, sentido. (Tese de Doutorado). Universidade Federal de Santa Maria, Programa de Pós-Graduação em Letras, Santa Maria.

Köhler Ortofacial. (2011). Zumbido pode ser gerado no ouvido interno. Köhler Ortofacial, 02 abr. 2011. Recuperado a partir de https://kohlerortofacial.files. wordpress.com/2011/03/ouvido_interno_by_marciolcastro.jpg.

Kübler-Ross, E. (1998). Sobre a morte e o morrer. São Paulo: Martins Fontes (Trabalho original publicado em 1969).

Kurtzer-White, E., \& Luterman, D. (2003). Families and children with hearing loss: grief and coping. Mental Retardation and Developmental Disabilities Research Reviews, 9(4), 232-235.

Laborit, E. (1996). O grito da gaivota. São Paulo: Caminho.

Lanzieri, T. M., Pinto, D., \& Prevots, D. R. (2007). Impacto da vacinação contra rubéola na ocorrência da síndrome da rubéola congênita. Jornal de Pediatria, 83(5), 415-421. http://dx.doi.org/10.1590/S0021-75572007000600004.

Lebovici, S. (1987). O bebê, a mãe e o psicanalista. Porto Alegre: Artes Médicas. 
Lebovici, S. (2004). Diálogo Letícia Solis-Ponton e Serge Lebovici. In L. SolisPonton, L. (Org.), Ser pai, ser mãe. Parentalidade: um desafio para o terceiro milênio (pp. 21-23). São Paulo: Casa do Psicólogo.

Lei n ${ }^{\circ}$ 10.436, de 24 de abril de 2002. (2002). Dispõe sobre a Língua Brasileira de Sinais - Libras e dá outras providências. Diário Oficial da União, Brasília. Recuperado a partir de http://www.planalto.gov.br/ccivil_03/_ato20072010/2010/lei/112303.htm.

Lei $\mathrm{n}^{\mathrm{o}}$ 12.303, de 2 de agosto de 2010. (2010). Dispõe sobre a obrigatoriedade de realização do exame denominado Emissões Otoacústicas Evocadas. Diário Oficial da União, Brasília. Recuperado a partir de http://www.planalto.gov.br/ccivil_03/_ato2007-2010/2010/lei/l12303.htm.

Lima, M. C., Boechat, H. A, \& Tega, L. M. (2003). Habilitação Fonoaudiológica da surdez: Uma experiência no Cepre / FCM / Unicamp. In I. R. Silva, S. Kauchakje \& Z. M. Gesueli (Orgs.), Cidadania, surdez e Linguagem: Desafios e realidades (pp. 41-49). São Paulo: Plexus.

Longato-Morais, C., Prado, M., \& Yamada, M. (2017). Implante coclear e transtorno do espectro autista: vivência de mães. Psicologia e Estudo, 22(4), 551561. doi: 10.4025/psicolestud.v22i4.35371

Luterman, D.M. (1979). Counseling parents of hearing impaired children. Boston: Little Brown.

Luterman, D. M., Kurtzer-White, E., \& Seewald, R. C. (1999). The young deaf child. Baltimore, Maryland: York Press.

Magalhães, A. M., Pérez Ramos, A. M., Neme, C. M., \& Yamada, M. (2007). Desenvolvimento socioemocional de crianças surdas com implante coclear. Boletim Academia Paulista de Psicologia, 27(2).

Mahl, F., Nóro, L., Zanini, A., Kessler, T., \& Biaggio, E. (2013). Vivência materna e o diagnóstico tardio da deficiência auditiva infantil. Revista Brasileira de Medicina, 49(10), 442-446.

Mannoni, M. (1996). A Criança Retardada e a Mãe. São Paulo: Martins Fontes, 1999.

Marchand, D., Rech, R., Benvenutti, S., Soldera, C., \& Machado, M. (2016). Orientações e incentivo ao teste da orelhinha em hospital filantrópico. Revista Ciência em Extensão, 12(2), 70-78.

Medeiros, C. S., \& Salomão, N. M. R. (2012). Concepções maternas sobre o desenvolvimento da criança deficiente visual. Revista Brasileira de Educação Especial, 18(2), 283-300. http://dx.doi.org/10.1590/S1413-65382012000200008 
Miniti, A., Bento, R. F., \& Butugan, O. (2001). Otorrinolaringologia clínica e cirúrgica, embriologia, anatomia e fisiologia do ouvido (2a ed.). São Paulo: Atheneu.

Moura, M. C. (2000). O surdo: caminhos para uma nova identidade. Rio de Janeiro: Revinter.

Negrelli, M. E. D., \& Marcon, S.S. (2006). Família e crianças surdas. Ciência, Cuidado e Saúde, 5(1), 98-107. doi: 10.4025/cienccuidsaude.v5i1.5146.

Neimeyer, R. (2001). Meaning reconstruction and the experience of loss. Washington: American Psychological Association.

Neuber, L. M., Valle, T. G. \& Palamin, M. E. (2008). O adolescente e a deficiência auditiva: as relações familiares retratadas no teste do desenho em cores da família. Revista Brasileira Crescimento Desenvolvimento Humano, 18(3), 321338.

Oliveira, C. T., Cúnico, S. D., Cunha, L. G., Kruel, C. S., \& Tochetto, T. M. (2013). O impacto do diagnóstico de surdez infantil e suas repercussões na vida da criança e de seus familiares. Disciplinarum Scientia, 14(1), 81-94. Recuperado a partir de www.researchgate.net/publication/281272855_O_impacto_do_ diagnostico_de_surdez_infantil_e_suas_repercussoes_na_vida_da_crianca_e_de_ seus_familiares.

Oliveira, I. G., \& Poletto, M. (2015). Vivências emocionais de mães e pais de filhos com deficiência. Revista da SPAGESP, 16(2), 102-119.

Oliveira, M. D., Silva, M. B., Frota, M. A., Pinto, J. M., Frota, L. M., \& Sá, F. E. (2008). Qualidade de vida do cuidador de crianças com paralisia cerebral. Revista Brasileira em Promoção da Saúde, 21(4), 275-280. doi: 10.5020/573

Oliveira, R. G, Simionato, M. A. W, Negrelli, M. E. D., \& Marcon, S. S. (2004). A experiência de famílias no convívio com a criança surda. Acta Scientiarum Health Science, 26(1), 83-191.

Pacheco, V. (2012). 95\% dos pacientes são beneficiados com o aparelho auditivo. Veronicapacheco.wordpress, 05 mar. 2012. Recuperado a partir de https://veronicapacheco.wordpress.com/2012/03/05/95-dos-pacientes-saobeneficiados-com-o-aparelho-auditivo/.

Padden, C. (1989). The deaf community and the culture of deaf people. In S. Wilcox (Org.), American deaf culture: an anthology. Burtonsville: Lindtok Press.

Parkes, C. (1998). Luto: estudos sobre a perda na vida adulta (3 ${ }^{\text {a }}$ ed). São Paulo: Summus.

Paula, A. S., \& Pereira, M. M. B. (2014). Manual informativo para pais: conhecendo melhor a surdez. Revista Espaço, 41(1), 65-79. 
Peñazola-López, Y. R., Castillo-Maya, G., García-Pedroza, F., \& Sánchez-López, H. (2004). Hypoacusis-deafness related to perinatal adverse conditions. According to the register available in a specialized unit of Ciudad de Mexico. Analysis according to birth weight. Acta Otorrinolaringol Esp, 55(6), 252-259.

Pereira, T., Costa, K. C., Pomilio, M. C., Costa, S. M., Rodrigues, G. R., \& Sartorato, E. L. (2014). Investigação etiológica da deficiência auditiva em neonatos identificados em um programa de triagem auditiva neonatal universal. Revista CEFAC, 16(2), 422-429. doi: 10.1590/1982-0216201419712.

Petean, E. B., \& Murata, M. F. (2000). Paralisia cerebral: conhecimento das mães sobre o diagnóstico e o impacto deste na dinâmica familiar. Paidéia, 10(19), 4046. http://dx.doi.org/10.1590/S0103-863X2000000200006.

Quadros, R. M. (2008). Educação de surdos: a aquisição a linguagem. Porto Alegre: Artmed.

Quevedo, R. F., Dambrós, S. \& Sassi, R. (2017). Grupo de mães ouvintes de filhos surdos: relato de uma experiência de estágio. Psicologia em Estudo, 22(1), 107-115. doi: 10.4025/psicolestud.v22i1.31794.

Ruggieri-Marone, M., Lichtig, I., \& Marone, S. A. (2002). Recém-nascidos gerados por mães com alto risco gestacional: estudo das emissões otoacústicas produtos de distorção e do comportamento auditivo. Revista Brasileira de Otorrinolaringologia, 68(2), 230-237. http://dx.doi.org/10.1590/S003472992002000200012.

Ribeiro, S. F. R., Yamada, M. O., \& Tavano, L. D. A. (2007). Vivência de mães de crianças com deficiência auditiva em sala de espera. Psicologia em Revista, 13 (1), 91-106.

Rossi, T. R. F. (2003). Mãe ouvinte/filho surdo: a importância do papel materno no contexto do brincar. In I. R. Silva, S. Kauchakje, \& Z. M. Gesueli (Orgs.), Cidadania, surdez e linguagem: desafios e realidades (pp. 99-112). São Paulo: Plexus Editora.

Sá, N. R .L. (1999). Educação de surdos: a caminho do bilinguismo. Niterói: EdUFF.

Sá, S., \& Rabinovich, P. (2006). Compreendendo a família da criança com deficiência física. Revista Brasileira Crescimento Desenvolvimento Humano, 16(1), 68-84. doi: 10.7322/jhgd.19782.

Sacks, O. (2010). Vendo vozes: uma viagem ao mundo dos surdos. São Paulo: Editora Schwarcz.

Santos, M. F., Lima, M. C., \& Rossi, T. R. (2003). Surdez: Diagnóstico Audiológico. In R. Silva, S. Kauchakje, \& Z. M. Gesueli (Orgs.), Cidadania, surdez e linguagem desafios e realidade (pp. 17-40). São Paulo: Plexus. 
Sass-Lehrer, M. (2012). Early intervention for children birth to 3: Families, communities, and communication. A resource guide for early hearing detection and intervention, 1-16.

Silva, A. B. P. (2010). Surdez, inteligência e afetividade. In I. R. Silva, S. Kauchakje, \& Z. M. Gesueli (Orgs.), Cidadania, surdez e linguagem: desafios e realidades ( $3^{\text {a }}$ ed., pp. 89-97). São Paulo: Plexus Editora.

Silva, A. B. P., Pereira, M. C. C., \& Zanolli, M. L. (2012). Surdez: da suspeita ao encaminhamento. Revista Paulista de Pediatria, 30(2), 257-62.

Silva, A. B. P., Zanolli, M. L., \& Pereira, M. C. C. (2008). Surdez: relato de mães frente ao diagnóstico. Estudos de Psicologia, 13(2), 175-183.

Silva, L. S. G. \& Gonçalves, C. G. O. (2013). Processo de diagnóstico da surdez em crianças na percepção de familiares e gestores. Audiology - Communication Research, 18(4), 293-302. doi: 10.1590/S2317-64312013000400010.

Skliar, C. (1998). Um olhar sobre o nosso olhar acerca da surdez e das diferenças. In C. Skliar (Org.), A surdez: um olhar sobre as diferenças (pp. 7-32). Porto Alegre: Mediação.

Stelling, E. P., Stelling, L. F. P., Santos Torres, E. M., \& Castro, H. C. (2014). Pais ouvintes e filho surdo: dificuldades de comunicação e necessidade de orientação familiar. Revista Espaço, (42), 15-25.

Stern, D. (1997). A constelação da maternidade. Porto Alegre: Artes Médicas.

Strobel, K. (2009). As imagens do outro sobre a cultura surda ( $\left.2^{\mathrm{a}} \mathrm{ed}\right)$. Florianópolis: Ed. da UFSC.

Stroebe, M., \& Schut, H. (1999). The dual process model of coping with bereavement: rationale and description. Death studies, 23, 197-224.

Teixeira, G., Paiva, A. B., \& Lima, M. C. M. P. (2015). Concepção sobre surdez na perspectiva de mães de crianças surdas. Saúde, 41(1), 93-104. doi: $10.5902 / 2236583412881$.

Travassos-Rodriguez, F., \& Féres-Carneiro, T. (2012). Os bebês com síndrome de Down e seus pais: novas propostas para intervenção. Estudos de Psicologia, 29, 831-840. doi: 10.1590/S0103-166X2012000500019.

Trindade, L.P. (2017). As percepções dos pais de pessoas surdas. Pretextos, 2(4), 141-156.

Valla, V. V. (1999). Educação popular, saúde comunitária e apoio social numa conjuntura de globalização. Cad. Saúde Pública, 15(2), 7-14. doi: 10.1590/S0102311X1999000600002. 
Vieira, E. P., Miranda, E. C. D., Azevedo, M. F. D., \& Garcia, M. V. (2007). Ocorrência dos indicadores de risco para a deficiência auditiva infantil no decorrer de quatro anos em um programa de triagem auditiva neonatal de um hospital público. Revista da Sociedade Brasileira de Fonoaudiologia, 12(3), 214-20. http://dx.doi.org/10.1590/S1516-80342007000300009

Vieira, S. S., Bevilacqua, M. C., Ferreira, N. M., \& Dupas, G. (2012). Descoberta da deficiência auditiva pela família: vendo o futuro idealizado desmoronar.

Revista Acta Paulista de Enfermagem, 25(2), 82-88.

http://dx.doi.org/10.1590/S0103-21002012000900013

Vilhena, E., Ribeiro, J. L. P., Silva, I., Pedro, L., Meneses, R. F., Cardoso, H., ... Mendonça, D. (2014). Factores psicossociais preditivos de ajustamento à vida de pessoas com doenças crônicas. Psicologia, Saúde \& Doenças, 15(1), 219-232. doi: $10.15309 / 14$ psd150118.

Walsh, F. (2005). Fortalecendo a resiliência familiar. São Paulo: Roca.

Widen, J. E., Bull, W. R., \& Folsom, R. C. (2003). Newborn hearing screening: What it means for providers of early intervention services. Infants \& Young Children, 16(3), 249-257.

Witkoski, S. A. (2009). Surdez e preconceito: a norma da fala e o mito da leitura da palavra falada. Revista Brasileira de Educação, 14(42), 565-606.

http://dx.doi.org/10.1590/S1413-24782009000300012

Witkoski, S. A. (2017). A interface entre a família e o direito ao ensino bilíngue para sujeitos surdos: rompendo oposições binárias. ETD-Educação Temática Digital, 19(3), 882-900.

Worden, J. W. (1998). Terapia do Luto. Porto Alegre: Artes Médicas.

World Health Organization (WHO). (2018). Deafness and hearing loss.

Recuperado a partir de http://www.who.int/news-room/fact-sheets/detail/deafnessand-hearing-loss.

Yamada, M., Moretti, C., Prado, M., \& Bevilacqua, M. (2014). A relação mãebebê com deficiência auditiva no processo de diagnóstico. Psicologia em Revista, 20(3), 460-478.

Yamada, M., \& Valle, E. (2014). Vivência de mães na trajetória de seus filhos com implante coclear: fatores afetivos emocionais. Ribeirão Preto: BookToy.

Yamanaka, D. A., Paiva e Silva, R. B., Zanolli, M. L., \& Paiva e Silva, A. B. (2010). Implante coclear em crianças: a visão dos pais. Psicologia: Teoria e Pesquisa, 26(3), 465-473. http://dx.doi.org/10.1590/S0102-37722010000300009.

Yamashiro, J. A., \& Lacerda, C. B. F. (2016). Ser irmão de uma pessoa surda: relatos da infância à fase adulta. Revista Brasileira de Educação Especial, 22(3), 367-380. doi: 10.1590/S1413-65382216000300005. 
Zaidman-Zait, A. (2008). Everyday problems and stress faced by parents of children with cochlear implants. Rehabilitation Psychology, 53 (2), 139-152.

Zornig, S. (2010). Tornar-se pai, tornar-se mãe: o processo de construção da parentalidade. Tempo Psicanalítico, 42(2), 453-470. 


\section{Anexo 1}

\section{Roteiro de entrevista}

Dados do entrevistado

Nome:

Idade:

Estado civil:

Escolaridade:

Ocupação:

Idade do filho(a):

Tipo de surdez e causa:

Tem outros filhos? Qual o sexo e idade:

Tema: Vivência da gravidez; as expectativas parentais

Como foi a gravidez do(a) seu filho(a)? (houve planejamento? como estava a relação do casal e da família durante a gravidez?)

Quais os sentimentos diante da notícia da gravidez?

Quais as expectativas que tinha acerca da criança? (sonhos e receios)

$\underline{\text { Tema: Confronto com a surdez }}$

Como foram os primeiros meses com o seu bebê?

Como foi a descoberta de que seu filho(a) era surdo? (quem percebeu, como foi, que idade ele tinha)

Me conta como foi quando você teve a confirmação do diagnóstico? (reação, sentimentos e pensamentos)

O que você sabia sobre surdez antes do diagnóstico?

Você teve algum apoio após o diagnóstico? Como foi?

O que mudou após o diagnóstico?

Tema: Vivência da parentalidade; relação com a família; rede de apoio; projeto de vida

Como é ser mãe/pai do(a) (nome da criança)?

Como foi e está o desenvolvimento/crescimento do seu filho(a)?

Houve alguma assistência terapêutica? (fonoaudiológica e outras)

Fale um pouco sobre o dia a dia com seu filho(a)? (interação/comunicação/rotina)

Como é a relação dele(a) com a família?

Que dificuldades você tem sentido?

Você já vivenciou alguma situação de preconceito devido a surdez do(a) seu filho(a)?

O que você deseja (sonha) para vida de seu filho(a)? Como você imagina a vida dele(a) no futuro?

Como a relação com o seu filho(a) te transformou? 


\section{Anexo 2}

\section{Pontifícia U Uiversidade $\mathrm{C}_{\text {atólica }}$ \\ DO RIO DE JANEIRC}

\section{Termo de Consentimento Livre e Esclarecido}

Prezado(a) senhor(a):

Viemos convidá-lo(a) a participar de uma pesquisa por meio da qual pretendemos compreender melhor como pais e mães ouvintes vivenciam a parentalidade com um filho surdo. Para que você possa decidir, precisa conhecer seus benefícios, riscos e implicações.

Instituição de origem: Pontifícia Universidade Católica do Rio de Janeiro

Título da pesquisa: "Ser pai/mãe de filhos surdos: um estudo sobre a parentalidade" Pesquisadora: Anielle Cristine F. Q. dos Santos

E-mail: anielle_cristine@yahoo.com.br Telefone: 21 97166-5330

Orientadora: Andrea Seixas Magalhães

E-mail: andreasm@puc-rio.br_

Telefone: 21 3527-1185

Comitê de Ética em Pesquisa da PUC-Rio Telefone: 21 3527-1618

A maioria (95\%) das crianças surdas são filhas de pais ouvintes, a maior parte destes pais não tem um histórico de surdez na família e, por vezes, nunca tiveram contato com uma pessoa surda. Diante dos poucos estudos sobre a vivência desses cuidadores, percebe-se a importância de uma melhor compreensão do processo de tornar-se pai/mãe de uma criança surda. Contribuindo para maior eficácia na intervenção junto aos surdos e seus familiares.

Esta pesquisa será realizada por meio de uma entrevista gravada e, posteriormente, transcrita, permanecendo sob a responsabilidade da pesquisadora os dados coletados, que serão armazenados em computador próprio, protegido por senha. Todas as informações têm caráter confidencial, portanto, sua identidade será 
mantida em sigilo. Seu nome e de todos os indivíduos mencionados na entrevista serão substituídos por outros, fictícios.

Sua participação é voluntária, e você pode interromper a entrevista quando assim desejar; fazer as perguntas que julgar necessárias; recusar-se a responder perguntas ou falar de assuntos que lhe possam causar qualquer tipo de constrangimento. A participação nessa pesquisa não apresenta nenhum risco, à exceção, talvez, de certa timidez que algumas pessoas podem manifestar ao longo da entrevista. Em caso de constrangimento, a entrevista poderá ser interrompida por pedido do entrevistado. Sua recusa em participar desta pesquisa não trará nenhum prejuízo em sua relação com o pesquisador ou com a instituição.

Com sua adesão, você irá contribuir para a ampliação do conhecimento sobre a vivência da parentalidade com filhos surdos. Dessa forma, auxiliando os pais ouvintes na relação com seus filhos surdos desde os primeiros momentos dessa realidade, oferecendo subsídios para promover a saúde da família.

Assinando este formulário de consentimento, você irá autorizar a pesquisadora a utilizar, em ensino, pesquisa e publicação, as informações prestadas na entrevista, sendo preservada sua identidade e a dos membros da sua família. Você não terá nenhum tipo de despesa por participar desta pesquisa e nada será pago por sua participação. Você poderá ter acesso aos relatórios da pesquisa contendo os resultados do estudo. Sempre que quiser poderá pedir mais informações sobre a pesquisa e entrar em contato com a pesquisadora.

Este Termo de Consentimento Livre e Esclarecido será fornecido em duas vias, sendo que, quando assinadas, uma ficará com a pesquisadora e outra com o participante.

Rio de Janeiro,

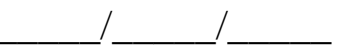

Assinatura da pesquisadora

Assinatura da entrevistada

Anielle Cristine F. Q. dos Santos 